Western University Scholarship@Western

Business Publications

Business (Richard Ivey School of Business)

$10-2016$

\title{
An Empirical Assessment of Empirical Corporate Finance
}

Jeffrey L. Coles

University of Utah

Zhichuan Frank Li

Western University, fli@ivey.ca

Follow this and additional works at: https://ir.lib.uwo.ca/iveypub

Part of the Business Commons

Citation of this paper:

Coles, Jeffrey L. and Frank Li, Zhichuan, "An Empirical Assessment of Empirical Corporate Finance" (2016). Business Publications. 23.

https://ir.lib.uwo.ca/iveypub/23 


\title{
An Empirical Assessment of Empirical Corporate Finance
}

\author{
Jeffrey L. Coles* \\ David Eccles School of Business \\ University of Utah \\ jeff.coles@eccles.utah.edu \\ Zhichuan Frank Li \\ Ivey Business School \\ University of Western Ontario \\ fli@ivey.ca
}

JEL Classifications: G3, G30, G31, G32, G34, G35, C23, C58, J31, J33.

Keywords: Empirical corporate finance; Corporate governance; Capital structure; Dividend policy; Executive compensation; Delta; Vega; Corporate control; Antitakeover protections; Mergers and acquisitions; Board of directors; Leverage; Cash balances; Investment policy; Asset composition; Firm focus; R\&D intensity; Firm risk; Dividend payout; Firm performance; Tobin's Q; ROA.

*Corresponding author.

**We thank seminar participants at Arizona State University, University of Western Ontario, the Northern Finance Association meetings 2013, and FMA Asia meetings 2013, and Campbell Harvey for helpful comments. 


\title{
An Empirical Assessment of Empirical Corporate Finance
}

\begin{abstract}
We empirically evaluate 20 prominent contributions to a broad range of areas in the empirical corporate finance literature. We assemble the necessary data and then apply a single, simple econometric method, the connected-groups approach of Abowd, Karmarz, and Margolis (1999), to appraise the extent to which prevailing empirical specifications explain variation of the dependent variable, differ in composition of fit arising from various classes of independent variables, and exhibit resistance to omitted variable bias and other endogeneity problems.
\end{abstract}

In particular, we identify and estimate the role of observed and unobserved firm- and manager-specific characteristics in determining primary features of corporate governance, financial policy, payout policy, investment policy, and performance. Observed firm characteristics do best in explaining market leverage and CEO pay level and worst for takeover defenses and outcomes. Observed manager characteristics have relatively high power to explain CEO contract design and low power for firm focus and investment policy. Estimated specifications without firm and manager fixed effects do poorly in explaining variation in CEO duality, corporate control variables, and capital expenditures, and best in explaining executive pay level, board size, market leverage, corporate cash holdings, and firm risk. Including manager and firm fixed effects, along with firm and manager observables, delivers the best fit for dividend payout, the propensity to adopt antitakeover defenses, firm risk, board size, and firm focus. In terms of source, unobserved manager attributes deliver a high proportion of explained variation in the dependent variable for executive wealth-performance sensitivity, board independence, board size, and sensitivity of expected executive compensation to firm risk. In contrast, unobserved firm attributes provide a high proportion of variation explained for dividend payout, antitakeover defenses, book and market leverage, and corporate cash holdings. In part, these results suggest where empiricists could look for better proxies for what current theory identifies as important and where theorists could focus in building new models that encompass economic forces not contained in existing models.

Finally, we assess the relevance of omitted variables and endogeneity for conventional empirical designs in the various subfields. Including manager and firm fixed effects significantly alters inference on primary explanatory variables in 17 of the 20 representative subfield specifications. 


\section{An Empirical Assessment of Empirical Corporate Finance}

\section{Introduction, Framework for Analysis, and Overview}

We empirically evaluate recent, prominent contributions to a broad spectrum of areas in the empirical corporate finance literature. We assemble the necessary data and then apply to each representative regression model the method of Abowd, Karmarz, and Margolis (1999, AKM). ${ }^{1}$ This approach allows the empiricist, through construction of "connected-groups," to separately identify manager and firm fixed effects in a way that was not previously possible. Using the AKM approach, we appraise and quantify the extent to which prevailing empirical specifications explain variation of the dependent variable, differ in composition of fit arising from various classes of independent variables, and exhibit resistance to omitted variable bias and other endogeneity problems.

In one sense, our project is quite modest. We apply a single econometric approach across various empirical studies. This allows a relatively even-handed comparison of progress in the various subfields. In other dimensions, our research thrust is ambitious. It requires data collection and analysis for a large number of regression specifications. It assesses empirical performance across a wide spectrum of subfields in corporate finance and, in a broad sense, indicates varying research opportunities for empiricists and theorists across those subfields.

To be more specific, we select recent papers, each containing one or more regression specifications that are approximately representative of the current state of progress in a subfield of empirical corporate finance. To assess current progress and set a benchmark for comparison, we re-estimate that representative specification using our

\footnotetext{
${ }^{1}$ To our knowledge, Graham, Li, and Qiu (2011) were the first to apply the connected groups method to corporate finance.
} 
sample period with time fixed effects. We then build on each benchmark specification by adding firm fixed effects alone, manager fixed effects alone, and finally, by using AKM, both firm and manager fixed effects. Based on the version with all five classes of explanatory variables, we decompose variation in the dependent variable into the unexplained portion and the portions explained by each of observed firm characteristics, observed manager attributes, and time, firm, and manager fixed effects.

Variation explained by observed firm and manager characteristics represents how successful empiricists are in explaining the dependent variable and provides evidence on the economic content and explanatory power of theory. Moreover, to the extent that variation in the dependent variable is "explained" by the various fixed effects, and insofar as those fixed effects represent unobserved manager and firm characteristics, we will know more about the nature of our gaps in knowledge about the determinants of the dependent variable. The attribution of that explained variation to unobserved manager or firm characteristics or to time fixed effects indicates to empiricists where to look for better observable proxies for factors that theory suggests are important and suggests to theorists where to focus new attention so as to identify additional economic determinants of organization structure, policy, or performance.

The subfields and specific empirical questions in corporate governance we consider include: executive compensation (pay level, wealth-performance sensitivity, and risk incentives), board structure (independence, size, and leadership structure), and corporate control (usage of antitakeover provisions and propensity to be a merger target or bidder). For payout policy we examine the propensity to pay dividends. For financial policy, we examine book and market leverage and cash balances. Specific aspects of investment policy we analyze are R\&D intensity, capital expenditure, firm focus, and 
firm risk. Measures of firm performance we consider are ROA and Tobin's $Q$. Table 1 stipulates the 20 experiments we perform and the published studies that provide the specific underlying benchmark specifications. Table 1 also provides information on the dependent variable, other aspects of our analysis, and results. Figures 1-6 comprise graphical representation, for all 20 empirical experiments, of benchmark goodness of fit and the composition of variation in the dependent variable attributable to each of the five classes of variables and to the residual. Figure 7, in aggregating Figures 2-6, captures all of these results in one location. Inspection of Figures 1-7 will give the reader an immediate sense for our approach and results. For additional detail, see Table 1.

By way of illustration and motivation, consider two sub-fields that have attracted substantial attention - managerial compensation contract design and capital structure. For the former, there have been numerous empirical attempts to explain compensation level, the sensitivity of managerial wealth to shareholder value (delta), and the sensitivity of expected managerial wealth to stock price volatility (vega). The standard agency model (e.g., Mirrlees, 1976, and Holmstrom, 1979) is a conventional way to understand contract design and frame empirical work, particularly for delta. While the essential characteristics of firms and managers identified in the agency model are not directly observable, prior studies employ a logical set of proxies for variables that should determine delta. ${ }^{2}$ Despite the power of the logic and the appeal of the proxies, the accumulated evidence is disappointing. There is substantial variation in results across studies and explanatory power is poor, with adjusted $\mathrm{R}^{2}$ often less than $10 \%$ in early specifications for delta without firm fixed effects (Gaver and Gaver, 1993; Bizjak,

\footnotetext{
${ }^{2}$ For the marginal value of effective managerial input or human capital on firm performance, measures include firm size, the ratio of market value to book value of assets, and R\&D. Proxies for managerial ability include tenure, age, and board seats. Proxies for managerial risk aversion include age, gender, and tenure.
} 
Brickley, and Coles, 1993). Perhaps incentive alignment through contract design is particularly impervious to application of standard regression specifications and explanatory proxies. Consider, instead, financial policy, specifically firm leverage. In assessing the prior literature, Lemmon, Roberts, and Zender (2008) note that the adjusted $\mathrm{R}^{2}$ from traditional leverage regressions using previously identified determinants ranges from $18 \%$ to $29 \%$, depending on sample period and the specification. After 60 years of work on the topic, these fit figures do not seem to reflect great progress.

Similarly, the results are mixed using recent specifications and our data. As Figure 1 indicates, using observable firm and manager characteristics and time fixed effects, the Lemmon, Roberts, and Zender (2008) specification for book leverage yields adjusted $\mathrm{R}^{2}$ of 0.23 and the Coles, Daniel, and Naveen (2006) specification for delta delivers adjusted $\mathrm{R}^{2}$ of 0.25 . In terms of comparative fit, Figure 1 shows that these two regression models and the subfields they represent fall in the middle, ranking ninth and eleventh among the 20 cases we consider. At the top end, adjusted $\mathrm{R}^{2}$ is highest for firm risk as the dependent variable (0.48) and lowest when the specification attempts to explain the propensity to put in place a poison pill (0.07).

To simultaneously assess sources of fit and suggest how researchers might do better, we re-estimate the benchmark specifications with firm and manager fixed effects included and identified by the approach of AKM (1999). When we include all five classes of explanatory variables and the residual, firm and manager observables provide proportions 0.088 (Figure 2) and 0.006 (Figure 3), respectively, of total variation in book leverage. Observed firm characteristics perform far better than observed manager characteristics. This makes some sense, as capital markets, product markets, production technologies, and corresponding industry norms, along with tax policy and bankruptcy 
law, are likely to be more important determinants of capital structure than manager characteristics. Nonetheless, variation explained by observed proxies is low and including manager and firm fixed effects boosts adjusted $\mathrm{R}^{2}$ for book leverage to 0.74 . The proportion of total variation in book leverage explained is 0.715 arising from unobserved (to the econometrician) firm and manager attributes in total, with firm fixed effects providing 0.511, second among 20 subfields (Figure 4), and manager fixed effects providing 0.209, eighteenth among 20 subfields (Figure 5).

For executive wealth-performance sensitivity (delta), firm and manager observables explain proportions 0.125 and 0.052 , respectively, of variation in delta. Including manager and firm fixed effects boosts adjusted $\mathrm{R}^{2}$ to 0.75 . For explained variation in managerial wealth-performance sensitivity, 0.629 arises from unobserved firm and manager attributes, with 0.598 contributed by manager fixed effects, first among 20 subfields, and 0.031 from firm fixed effects, which is last among subfields. Time fixed effects explain a small proportion, 0.010, of variation in delta (see Figure 6).

These results help us understand what we do not know. In the above two examples, either we utilize poor proxies for firm and manager attributes motivated by our models or we need new models. For capital structure, researchers reasonably would concentrate on better proxies and new theories related to characteristics of the firm and the markets in which it operates, a conclusion that is reminiscent of Lemmon, Roberts, and Zender (2008). The prescription is very different for contract design. Researchers reasonably would work to develop better proxies for managerial attributes isolated in existing models and on new theories that identify other characteristics of executives relevant for contract design. See the columns designated " $\mathrm{C} 1$ : Delta" and "F1: Book Leverage" in Figure 7. 
Our analysis makes possible the same style of discussion for all of the areas in empirical corporate finance that we assess. In broad terms, estimated specifications without firm and manager fixed effects do poorly in explaining variation in CEO duality, corporate control variables, and capital expenditure, and best in explaining executive pay level, board size, market leverage, corporate cash holdings, and firm risk. Including manager and firm fixed effects, along with firm and manager observables, delivers the best fit for dividend payout, the propensity to adopt antitakeover defenses, firm risk, board size, and firm focus. In terms of source, unobserved manager attributes deliver a relatively high proportion of total variation in the dependent variable for executive wealth-performance sensitivity, board independence, board size, and sensitivity of expected executive compensation to firm risk. In contrast, unobserved firm attributes explain a high proportion of variation in dividend payout, antitakeover defenses, book and market leverage, and corporate cash holdings. Again, these results suggest where empiricists would look for better proxies for what current theory identifies as important and where theorists could focus in building new models that encompass economic forces not contained in existing models.

Finally, we assess the relevance of omitted variables and endogeneity for conventional empirical designs in the various subfields. It is widely known that when unobservable manager or firm heterogeneity is correlated with observable characteristics, regression specifications that do not explicitly account for such heterogeneity can produce biased coefficient estimates (e.g., see Kennedy, 2003, on omitted variables). Our analysis indicates that this is a concern for at least 17 of the 20 areas of empirical inquiry in corporate finance that we assess. 
Our results contribute to the literature in several dimensions. First, the paper enlarges the empirical corporate finance literature by providing a relatively comprehensive empirical examination and comparison of overall empirical fit and sources of fit from observed independent variables across subfields. In doing so, we also gauge the role of unobserved firm and managerial heterogeneities in determining important aspects of organization design, policy, and behavior. Second, our empirical exploration of the economic content of the estimated manager fixed effects contributes to the growing literature on how unobservable versus observable managerial attributes affect corporate policy and performance. For example, in the case of executive contract design, beyond managerial skill and risk aversion our analysis accommodates the notion that managerial attributes heretofore unmeasured or inaccurately measured, such as social capital, psychological traits, personality, genetics, and functional background, influence firm structure, policy, and performance. Third, our analysis suggests where it is likely to be most productive for empiricists and theorists in corporate finance to allocate their time and effort. Fourth, our approach allows us to assess the relevance of omitted variables and endogeneity for conventional empirical designs in the various subfields. Including manager and firm fixed effects significantly alters inference in a number of instances.

Please note that our primary intent is not to be critical of the current state of empirical corporate finance, in general, or of specific contributions to the literature. Rather, our analysis identifies substantial progress in some areas of inquiry but less in others and, in some instances, ascertains potential research opportunities and plausible ways forward for both theorists and empiricists. Moreover, we are apologetic about not including many well-done and influential papers. Based on time and data limitations, we 
are constrained to evaluate a manageable number of subfields and a limited number of specifications.

Section 2 describes the empirical methodology. Section 3 discusses how we select the prior contributions to the literature upon which we build our analysis. Section 4 describes the data, variables, and summary statistics. Section 5 frames the approach and suggests what one can expect from the analysis. Sections 6-13 present the results for the areas of empirical corporate finance we examine. Section 6 treats executive contract design, including delta, vega, and pay level. Section 7 considers board structure, including independence, size, and leadership structure. Section 8 analyzes corporate control, specifically the propensities to make a bid, receive a bid, or adopt a poison pill. Section 9 addresses financial policy, specifically book leverage, market leverage, and corporate cash holdings, while Section 10 examines payout policy. Sections 11 and 12 examine the role of firm and manager attributes not observed by the econometrician in determining aspects of investment policy, including capital expenditures, R\&D intensity, firm risk, and firm focus. Section 13 examines the "determinants" of firm performance, as measured by Tobin's Q and ROA. Section 14 provides discussion of last tests. Section 15 provides concluding remarks. Again, for a preview of the results, please refer to Figure 7 and Table 1.

\section{Estimation Methodology}

We employ the group connection method of AKM (1999). We provide here a brief description. For illustration and more detail see Graham, Li, and Qiu (GLQ, 2011), who apply AKM to executive pay level, and Coles and Li (2016), who apply it to other 
aspects of executive compensation structure. See GLQ (2011) and Coles and Li (2016) for a discussion of method similar to that below.

The simplest way to include fixed effects is to create a dummy variable for each unique combination of manager and firm (i.e. for each employment spell). The "spell method" enlarges the feasible sample and addresses possible omitted variable bias, but it can only estimate the joint firm and manager effects and does not disentangle the two. Note that simply using firm dummies and manager dummies is insufficient for separating the effects. If a firm has no managerial turnover, the two effects are perfectly collinear.

This does suggest one way forward, which is to restrict the sample to cases in which the firm has at least one manager who has moved from one company to another. Potential difficulties with the mover dummy variables (MDV) approach include: selection bias from restricting the sample to movers only; small sample size arising from infrequent managerial turnover; and, computational difficulties from inverting a covariate matrix with many dummy variables. Bertrand and Schoar (2003), for example, use this approach, their purpose being to examine whether unobserved managerial heterogeneity has power to explain return on assets, investment, leverage, and cash holdings.

Relative to the MDV and spell approaches, the method of Abowd, Karmarz, and Margolis (1999) achieves separate "identification" of the firm and manager fixed effects but still retains a substantial portion of the sample. The intuition is fairly simple. Consider a manager who switches firms once during the sample period. The fixed effect for this manager can be estimated, as can be the fixed effects for the two firms that employed the manager. Based on the firm fixed effects, the fixed effects for all other managers at those two firms can also be estimated, even if they did not move. Removing all firms that never had a manager depart or arrive leaves groups of firms connected by 
managerial transitions. AKM (1999) prove that such connectedness is necessary and sufficient to separately identify firm and individual fixed effects. Again, this approach restricts sample attrition to executive-years arising from firms that employ the same group of executives for the entire sample period. Some manager mobility is the key ingredient that allows identification of both manager and firm fixed effects. We report results using the AKM method.

Firm and manager fixed effects represent characteristics that are unobservable to the econometrician. Note that, for any unobserved factor to affect the dependent variable, at least one decision-maker must have at least some information on that attribute. Write the dependent variable for firm $i$ and manager $j$ at time $t, y_{i j t}$, as:

$$
y_{i j t}=F_{i t} \hat{\beta}+M_{j t} \hat{\alpha}+\hat{\mu}_{i}+\hat{\theta}_{j}+\hat{\lambda}_{t}+\varepsilon_{j t}
$$

where the right-hand side is comprised of observable time-variant firm characteristics $\left(F_{i t} \hat{\beta}\right)$, observable time-variant manager characteristics $\left(M_{j t} \hat{\alpha}\right)$, firm fixed effects $\left(\hat{\mu}_{i}\right)$, manager fixed effects $\left(\hat{\theta}_{j}\right)$, year fixed effects $\left(\hat{\lambda}_{t}\right)$, and residuals $\left(\hat{\varepsilon}_{j t}\right)$. Hat denotes an estimate of a parameter or a vector of parameters $i$ indexes firms, $j$ indexes managers, and $t$ indexes time..

To provide a quantitative comparison of the relative economic significance of the classes of variables, we follow GLQ (2011) to decompose variation of the dependent variable (delta or vega) into five estimated components and the unexplained remainder. Based on equation (1), model $\mathrm{R}^{2}$ can be decomposed as: 


$$
\begin{aligned}
& R^{2}=\frac{\operatorname{cov}\left(\hat{y}_{i j t}, y_{i j t}\right)}{\operatorname{var}\left(y_{i j t}\right)}=\frac{\operatorname{cov}\left(F_{i t} \hat{\beta}+M_{j t} \hat{\alpha}+\hat{\mu}_{i}+\hat{\theta}_{j}+\hat{\lambda}_{t}, y_{i j t}\right)}{\operatorname{var}\left(y_{i j t}\right)} \\
& =\frac{\operatorname{cov}\left(F_{i t} \hat{\beta}, y_{i j t}\right)}{\operatorname{var}\left(y_{i j t}\right)}+\frac{\operatorname{cov}\left(M_{j t} \hat{\alpha}, y_{i j t}\right)}{\operatorname{var}\left(y_{i j t}\right)}+\frac{\operatorname{cov}\left(\hat{\mu}_{i}, y_{i j t}\right)}{\operatorname{var}\left(y_{i j t}\right)}+\frac{\operatorname{cov}\left(\hat{\theta}_{j}, y_{i j t}\right)}{\operatorname{var}\left(y_{i j t}\right)}+\frac{\operatorname{cov}\left(\hat{\lambda}_{t}, y_{i j t}\right)}{\operatorname{var}\left(y_{i j t}\right)}
\end{aligned}
$$

Of course, 1 - model $\mathrm{R}^{2}$ is the proportion of variation attributable to the residual. Figures $2-7$ report on the components of total variation attributable to the five classes of variables, per (2), with Figure 7 also including residual variation.

Another comparison is based on the proportion of $R^{2}$, explained variation, provided by each class of variable. Normalizing the components in (2) gives:

$$
\frac{\operatorname{cov}\left(F_{i t} \hat{\beta}, y_{i j t}\right)}{R^{2} \operatorname{var}\left(y_{i j t}\right)}, \frac{\operatorname{cov}\left(M_{j t} \hat{\alpha}, y_{i j t}\right)}{R^{2} \operatorname{var}\left(y_{i j t}\right)}, \frac{\operatorname{cov}\left(\hat{\mu}_{i}, y_{i j t}\right)}{R^{2} \operatorname{var}\left(y_{i j t}\right)}, \frac{\operatorname{cov}\left(\hat{\theta}_{j}, y_{i j t}\right)}{R^{2} \operatorname{var}\left(y_{i j t}\right)}, \quad \text { and } \frac{\operatorname{cov}\left(\hat{\lambda}_{t}, y_{i j t}\right)}{R^{2} \operatorname{var}\left(y_{i j t}\right)}
$$

Table 1 provides a comprehensive summary but with fit comparisons based on attribution of explained variation in the dependent variable, as in (3), rather that attribution of total variation (including the residual) of the dependent variable.

\section{Representative Specifications}

To reduce the data requirements for our analysis and for brevity, we choose one published contribution to the literature in each area and, further, one or a small number of regression specifications from that paper, which we then re-estimate using the approach

of AKM. All else equal, we choose papers that are recent and also are as representative as possible of the prevailing, mainstream empirical designs in that subfield. In addition, given the scale of our empirical undertaking, we favor specifications for which the required data are not too costly to obtain. In most areas, multiple papers meet some of these criteria, though generally no prior paper dominates on all dimensions. Accordingly, 
we make some arbitrary choices in selecting benchmark papers and specifications. It should be clear that this reflects pragmatism and the desire to manage data collection costs and other costs rather than a conclusion that one prior paper necessarily is a better product than another.

The headings in Table 1 specify the full set of 20 sub-fields in empirical corporate finance that we examine and the corresponding contributions to those sub-fields that we select to build on and enlarge. The table identifies the papers we emphasize, the particular specification we use as the benchmark, and the dependent variable. We select 20 different specifications (arising from 9 different papers) to duplicate and re-examine using AKM. Again, the broad topic areas we consider are compensation policy, board structure, corporate control, financial policy, payout policy, investment policy, firm diversification/focus, and firm performance.

\section{Assembling the Samples}

We begin with all executive-year observations from Execucomp for firms with fiscal years ending from 1993 to 2013. For a firm-year this includes up to five named executive officers (NEOs). Firm-executive-year observations carry the subscript ijt. We include the CEO, who is likely to have the most discretion, span of control, and effect on structure, policy and performance, but also include the other NEOs for the reason that top management team attributes tend to predict organizational attributes better than CEO attributes alone (Hambrick, 1994). Including NEOs, to the extent they switch firms, also allows in more cases identification of the firm and manager fixed effects. We exclude any observations without matching CRSP and Compustat North America data and, consistent with prior literature, we eliminate financial services and utility firms from the 
sample. The full sample to which the spell approach could apply consists of 14,137 executive-year observations. Restricting the sample to include movers only would reduce considerably the number of observations to 12,360 . The approach of AKM, which allows identification of both firm and manager fixed effects, generates connected subsamples that aggregate to 83,670 executive-firm-year observations arising from 1,517 firms and 19,835 managers. Otherwise, for some experiments, data limitations reduce sample size.

We obtain corporate governance data from RiskMetrics Governance, director data from RiskMetrics Directors, daily stock returns and prices from CRSP, executive compensation data from ExecuComp, company diversification information from the Compustat Segment data, corporate bond information from Compustat Ratings data, information on institutional holdings from Thomson Reuters data, and all other financial items from Compustat Fundamentals. For data on corporate control and mergers and acquisitions, we rely on SDC Platinum. We follow Coles, Daniel and Naveen (2011, Appendix) in adjusting Execucomp data for reporting changes based on the 2006 implementation of FAS123R. For brevity, we provide variable definitions in the Appendix and defer any detailed discussion of specific variables until the relevant subsection. Table 2 reports summary statistics. Inspection of those statistics indicates that our dependent and independent variables are characterized by sample moments similar to those reported in the representative prior studies.

The representative papers across the various subfields differ depending on variables employed, variable definitions, sample period, and thus sample size. In our analysis, towards the objective of a cleaner comparison across empirical questions, we use the same core sample of firms and managers over a common period. Some secondary variables, such as manager age and tenure, are often missing. To maximize sample size 
we define variables that indicate whether the variable is missing $(=1$, otherwise $=0)$, and set the variable itself equal to zero when the indicator equals 1 . This procedure follows a number of recent papers, including Himmelberg et al. (1999) and Byoun (2008).

\section{Remarks on What to Expect}

Recall that our analysis employs five classes of explanatory variables: observable attributes of firms; observable attributes of executives; year fixed effects; time-invariant firm fixed effects; and time-invariant manager fixed effects. Observable attributes of managers and firms can vary through time. The firm and manager fixed effects account for unobserved attributes of firms and managers that are stable through time. These attributes can be those that are imperfectly represented by included observables, but also could be characteristics that would be important in models not yet tested or understood or in theories not yet identified or articulated. Year fixed effects likely capture broad trends in the economic environment, such as macro conditions, and in unobserved firm and manager characteristics. The residual accommodates what is left, such as time-variation in the idiosyncratic unobserved firm and manager attributes, nonstationarity in the crosssectional effect of observed attributes, as well as noise.

The relative explanatory power of these variables should vary across research

questions. For example, one would expect managerial attributes, such as risk aversion, cost of effort, talent, general human capital, and firm-specific human capital to be important for the structure of managerial compensation and perhaps board structure and, firm performance. To the extent that observables are good proxies for these underlying attributes, then time-varying manager characteristics should have high explanatory power. If observed attributes are poor proxies (for risk aversion or talent, for example), then 
manager fixed effects are likely to have power. This also is true for other attributes newly identified by theory but not yet tested and traits not identified or isolated by theory. For example, managerial fixed effects accommodate the literature that asserts that psychological traits (Chatterjee and Hambrick, 2007; Malmendier and Tate, 2005, 2008; Hackbarth, 2008; Graham, Harvey, and Puri, 2009; Grable, 2000), personalities (Kaplan, Klebanov, and Sorensen, 2008), and functional background (e.g. Hambrick, 2007) influence firm policies and performance. Along the same lines, executive fixed effects can capture social capital, interpersonal networks, charisma, ability to self-regulate, religious beliefs, and genetic makeup. ${ }^{3}$

On the other hand, perhaps firm attributes, such as characteristics of the product market, cost structure, regulatory environment, asset base, and growth opportunities, are relatively more important for financial policy, such as aspects of the capital structure decision, investment policy, and perhaps firm performance as well. Then observable firm attributes and firm fixed effects will have explanatory power, with the mix being determined by the quality of the proxies, the insight and predictive power of existing theory, and the elements of theory not yet tested or developed. Of course, this is not a certain conclusion. Managerial characteristics, such as risk aversion, also are likely to shape decisions on leverage (e.g., Cronqvist, Makhija, and Yonker, 2010) and cash holdings. $^{4}$

\footnotetext{
${ }^{3}$ In this last respect, recent evidence suggests that genetic makeup has high explanatory power for job choice, satisfaction, and (poor) performance (Shane, 2010). Other evidence shows that genes affect behavior through bloodstream levels of neurotransmitters, such as serotonin and dopamine, and hormones, such as oxytocin and cortisol (see Homo admistrans: the biology of business, The Economist, September 25, 2010, pp. 99-101).

${ }^{4}$ A priori, managerial characteristics will not matter much in determining corporate policies if managerial discretion is lacking (Hambrick, 2007). For example, manager fixed effects are likely to matter more for investment policy as compared to financial policy, supposing that investment policy is more centrally located within the span of managerial discretion and control and managers have flexibility to determine investment policy.
} 
Overall fit, or the ability of all classes of variables combined to explain the dependent variable, also is likely to vary across subfields. Some aspects of empirical corporate finance are more mature and better developed empirically and/or theoretically. In contrast, the residual error will be larger in subfields that are less developed and in which the unobserved attributes and dependent variable are highly variable through time. The study of capital structure was initiated some 60 years ago (Modigliani and Miller, 1958), while the examination of the structure of managerial compensation is more recent (Holmstrom, 1979; Murphy, 1999). Thus, one would expect less residual variation for leverage as opposed to compensation level. Along these lines, Graham, Li, and Qiu (2011) note that "...(I)t is well known that labor market outcomes are extremely heterogeneous and that observationally equivalent individuals sometimes earn markedly different compensation.”

A final aspect of the analysis relates to how the inclusion of fixed effects can mitigate bias arising from omitted variables. Accordingly, we examine whether the inclusion of firm and manager fixed effects changes coefficient estimates and statistical inference for primary explanatory variables identified by leading theoretical models.

\section{Compensation Policy: Executive Contract Design}

We first consider compensation policy. We present our analysis and also use this particular aspect of empirical corporate finance to illustrate our approach. Accordingly, we present the results in more detail and with more discussion than will be typical in what follows. Given the span of the empirical analysis, brevity requires a more parsimonious approach in subsequent sections of the paper. 
Returning to compensation policy, the dependent variables we examine are pay level, the sensitivity of executive wealth to shareholder value (delta), and the sensitivity of expected executive wealth to volatility of shareholder value (vega). Our point of departure for delta and vega is Coles, Daniel, and Naveen (2006). We build on Graham, Li, and Qiu (2011) for pay level.

Unlike all of the other subfields of empirical corporate finance we assess below, compensation policy is the only area to have been examined using the method of AKM (1999). See Graham, Li, and Qiu (2011) on compensation level and Coles and Li (2016) for delta and vega. Though we use different data and sample period and our specifications herein differ slightly from theirs, our results are similar to those in the two prior papers.

Total compensation is TDC1 from Execucomp. We follow Coles, Daniel, and Naveen (2006), who follow Guay (1999) and Core and Guay (2002), to calculate accumulated delta and vega for each executive on an annual basis. Delta is defined as the change in the dollar value of the executive's wealth for a one percentage point change in stock price. Vega is the change in the dollar value of the executive's wealth for a 0.01 change in the annualized standard deviation of stock returns. Because option vega is many times higher than stock vega (Guay, 1999), Coles, Daniel and Naveen (2006) use vega of the option portfolio to measure the total vega of the stock and option portfolio. We winsorize delta and vega at the $1^{\text {st }}$ and $99^{\text {th }}$ percentiles. Please refer to the Appendix (Variable Definitions) for detailed definitions and Table 2 for summary statistics for these and other variables.

\subsection{Executive wealth-performance sensitivity (delta)}


Our benchmark specification for delta, meaning the specification that we adopt as roughly representative of the prior literature, is a pooled OLS regression, including time fixed effects but without firm or manager fixed effects (FE), which is based on the explanatory variables in the specification in Coles, Daniel, and Naveen (2006, Table 3, Panel A, Column 3), which resembles Core and Guay (1999, Table 2, Model 1), plus other selected observable managerial attributes. The estimates using our data and controls are reported under Model (1) in Panel A of Table 3. The adjusted $\mathrm{R}^{2}$ is 0.25 . Adding firm fixed effects increases adjusted $\mathrm{R}^{2}$ to 0.37 (Model (2)), while manager fixed effects alone boost adjusted $\mathrm{R}^{2}$ to 0.73 (Model (3)). Model (4) includes both firm and manager fixed effects to yield adjusted $R^{2}=0.75$.

Panel B of Table 3 reports the relative explanatory power of the classes of variables. Per equation (2), we calculate the covariances between dependent variables (delta and vega, respectively) and each of the components, normalized by the variance of dependent variable. These percentages are the fractions of the model sum of squares attributable to particular components. Applying the AKM method to delta with both manager and firm fixed effects (Model (4) of Panel A), observed firm attributes, observed manager attributes, firm fixed effects, manager fixed effects, and year fixed effects account for proportions 0.12 (ranked 4 among 20), 0.05 (3), 0.03 (20), 0.60 (1), and 0.01 (12) of total variation of delta, with proportional residual unexplained variation of 0.186 . Thus, unadjusted model $\mathrm{R}^{2}$ is 0.814 (Table 3, Panel B). Normalized by variation of delta explained by the model $(0.814=1.00-0.186)$, the five classes of variables contribute $15.32 \%(=0.124 /(1-0.186)), 6.37 \%(=0.052 /(1-0.186)), 3.8 \%, 73.28 \%$, and $1.23 \%$ of model $\mathrm{R}^{2}$, explained variation in delta, respectively. 
Column C1 in Figure 7 represents graphically the components of total variation. For delta, and for all other dependent variables, orange represents the share of the residual in variation of the dependent variable, light blue is observed managerial characteristics, purple is observed firm characteristics, green is year fixed effects, red is firm fixed effects, and blue is manager fixed effects. See Table 1 for sources of explained variation in delta.

While the percentage of total variation in delta arising from observed manager characteristics (0.052) seems low in absolute terms, Figure 3 indicates it is the third highest among the 20 experiments. Nonetheless, given the high explanatory value of time-invariant fixed effects (0.598, Figure 5), researchers would reasonably work to obtain better proxies for managerial attributes and to develop new theories that identify new managerial characteristics relevant for delta. Along these lines, perhaps Coles, Daniel and Naveen (2006) and predecessors employ poor proxies for managerial ability and risk aversion. Furthermore, perhaps they and other researchers would consider models that contain, as well as proxies that measure, for example, managerial reputation (Milbourn, 2003). Such forces, or social capital, genetics, or personality, for example, may be sources of the "explanatory power" of manager fixed effects for delta.

Table 1 includes information on whether including manager and firm fixed effects alters inference on other explanatory variables. In the case of delta, the most important change is that including the fixed effects changes the coefficient on firm risk to negative and significant from positive and significant. While a positive coefficient is consistent with numerous previous findings (e.g., Core and Guay, 1999, and Coles et al., 2006), the result is inconsistent with the predictions of the standard agency problem, ceteris paribus. In contrast, including firm and manager fixed effects yields a result that is quite different 
from the pooled OLS result without fixed effects but is consistent with Aggarwal and Samwick (1999, 2003) and Himmelberg et al. (1999) and the prediction of the leading model.

It is plausible that including the fixed effects successfully addresses omitted variable bias. For example, suppose firm risk has two opposing effects on delta. The direct effect is suggested by standard agency theory where, all else equal, delta will be lower the higher is firm risk because delta exposes managers to risk. The indirect effect is through employee-employer matching. Risk-tolerant managers are sorted to high risk firms and those managers are willing to accept higher delta than more risk-averse managers. The former effect predicts a negative relationship between firm risk and delta, while the latter suggests a positive one. If manager fixed effects and/or firm fixed effects absorb the matching effect, the specification isolates the direct effect of firm risk on delta.

\subsection{Compensation Vega}

The benchmark specification we select for vega is a pooled OLS regression, without firm or manager fixed effects, that is based on Coles, Daniel, and Naveen (2006, Table 3, Panel A, Column 2), which resembles Core and Guay (1999, Table 4, Model 4), plus other selected observable managerial attributes. Benchmark adjusted $\mathrm{R}^{2}$ is 0.28

(Model (1), Panel A, Table 4). Adding firm fixed effects increases adjusted $\mathrm{R}^{2}$ to 0.40 (Model (2)), while manager fixed effects boosts adjusted $\mathrm{R}^{2}$ to 0.47 (Model (3)). Model (4) includes both firm and manager fixed effects to yield adjusted $\mathrm{R}^{2}=0.49$.

As Panel B of Table 4 indicates, when normalized by variation of vega explained by the model $(0.626=1-0.374)$, the five classes of variables (observable firm attributes, observable manager attributes, firm fixed effects, manager fixed effects, and year fixed effects) contribute $19.3 \%(0.121 /(1-0.74)), 9.3 \%, 7.7 \%, 59.1 \%$, and $4.6 \%$ of model $\mathrm{R}^{2}$. 
See Table 1. Column C2 in Figure 1 represents graphically the unnormalized (by model $\mathrm{R}^{2}$ ) components of variation.

Risk aversion may be the most important determinant absorbed in managerial fixed effects. Effort focused on finding better proxies continues. For example, risk aversion can be proxied by cultural and political environment (Guiso, Sapienza, and Zingales, 2004, 2008). Malmendier and Nagel (2011) find individual experiences matter: in particular, "depression babies" exhibit lower willingness to take financial risk. In addition, Bergman and Jenter (2007) link stock option compensation to employee optimism.

Note that including manager and firm fixed effects yields a negative and significant coefficient on each of firm risk and market-to-book. Again, it is plausible that fixed effects mitigate a common endogeneity problem by controlling for important but unobservable underlying drivers of both firm characteristics and executive compensation.

\subsection{Compensation level}

The representative specification (Model (1), Panel A, Table 5) we select for compensation level is a pooled OLS regression, without firm or manager fixed effects, which is based on the explanatory variables in Graham, Li, and Qiu (2011, Table 4, Panel A, Column 1), plus selected observable managerial attributes and year fixed effects. Adding both firm and manager fixed effects improves adjusted $\mathrm{R}^{2}$ from the benchmark value of 0.35 to 0.67 . As Table 1 and Panel $\mathrm{B}$ of Table 5 indicate, normalized variation of total compensation explained is $20.2 \%, 10.9 \%, 8.3 \%, 47.1 \%$, and $13.8 \%$ of model $\mathrm{R}^{2}$ for observable firm attributes, observable manager attributes, firm fixed effects, manager fixed effects, and year fixed effects, respectively. These results are quite similar to those 
in Graham, Li, and Qiu (2011). See column C3 in Figure 7 for unnormalized attribution of variation in pay level.

In determining executive pay level, firm fixed effects are likely to represent, for example, complexity of the tasks that the executive faces in the firm and firm- (or industry-, region-, etc.) specific compensation practice. Manager fixed effects plausibly reflect managerial ability and other manager-specific factors, such as reputation (Malmendier and Tate, 2009). In terms of possible bias from omitted variables, including manager and firm fixed effects alters inference for manager age and changes the significance of several other coefficients.

\section{Board Structure}

The conventional wisdom is that independent boards, smaller boards, and boards that separate the CEO and chairman positions are better boards (see Coles, Daniel, and Naveen, 2008, for discussion). On the first of these, a greater level of board independence is thought to lead to effective monitoring and better firm performance. Indeed, some stock exchanges (e.g., NYSE) require that at least half the board be nonemployee directors. Several studies show how outside (non-management) directors on the board affect discrete tasks, including hiring and firing of the Chief Executive Officer (CEO) (Weisbach, 1988), adoption of antitakeover devices (Brickley, Coles, and Terry, 1994), and negotiating takeover premiums (Byrd and Hickman, 1992). In terms of board size, Jensen (1993) suggests that larger boards could be less effective than smaller boards because of coordination problems and director free-riding. Yermack (1996) provides evidence that smaller boards are associated with higher firm value, as measured by Tobin's Q. On the other hand, Coles, Daniel, and Naveen (2008) suggest that advising 
requirements and firm complexity can alter the balance of costs and benefits, so that bigger boards with more inside directors would be appropriate for some companies.

Brickley, Coles and Jarrell (1997) found that nearly $81 \%$ of large US companies in 1988 combined the CEO and chairman positions in one individual. Furthermore, they found no relation between firm performance and corporate leadership structure. Nonetheless, the conventional wisdom (e.g., the Conference Board) is that separating the positions is good governance and the recent trend has been towards separating the position, with nearly $40 \%$ of large US companies doing so more recently (Spencer Stuart, 2009: respondents from the 2009 (as of May 15) S\&P 500). Brickley, Coles and Jarrell (1997) and Baliga, Moyer, and Rao (1996) set forth the potential costs and benefits of combining and separating the positions.

\subsection{Board independence}

The benchmark specification (Model (1), Panel A, Table 6) is a pooled OLS regression, without firm or manager fixed effects $(\mathrm{FE})$, which is based on the explanatory variables in Linck, Netter, and Yang (2008, Table 4, Column 2), plus selected observable managerial attributes and year fixed effects. The dependent variable is the proportion of board members who are not executives of the company. Benchmark adjusted $\mathrm{R}^{2}$ is 0.25 (Model (1), Panel A, Table 6). Adding firm fixed effects increases adjusted $\mathrm{R}^{2}$ to 0.74 (Model (2)), while manager fixed effects boosts adjusted $\mathrm{R}^{2}$ to 0.73 (Model (3)). Model (4) includes both firm and manager fixed effects to yield adjusted $\mathrm{R}^{2}=0.76$.

As Panel B of Table 6 indicates, when normalized by variation of board independence explained by the model, the five classes of variables, observable firm attributes, observable manager attributes, firm fixed effects, manager fixed effects, and year fixed effects, contribute $2.6 \%, 0.8 \%, 27.4 \%, 59.7 \%$, and $7.2 \%$ of model $\mathrm{R}^{2}$ (Table 1 ). 
Column B1 in Figure 7 represents graphically the components of total variation in board independence.

Pertaining to the large explanatory share of manager fixed effects, there are several potential sources of managerial influence over board structure. For example, the selection of directors is largely influenced by the CEO (Shivdasani and Yermack, 1999). Consistent with the negotiation hypothesis in Hermalin and Weisbach (1998) and Baker and Gompers (2003), Boone, Field, Karpoff, and Raheja (2007) find board independence is negatively related to managerial influence. Furthermore, if a manager is highly capable or influential, she will be elected into the board, potentially decreasing board independence, increasing board size, and increasing the likelihood of CEO duality if she is a CEO. Manager fixed effects could capture the time-invariant portions of these factors.

Firm fixed effects are also important in determining board independence. This may reflect the likelihood that board structure is determined by scope and complexity of the firms operations (Coles, Daniel, and Naveen, 2008; Lehn, Patro, and Zhao, 2009) and is influenced by the specific business and information environment (e.g., Raheja, 2005; Harris and Raviv, 2008). Furthermore, although board governance often is an important control system, it clearly is not the only one. Firm fixed effects may capture some unobserved characteristics of other governance features that can supplement direct board monitoring. Examples are shareholder activism (Gillan and Starks, 2000), mutual monitoring among executives (Acharya, Myers, and Rajan, 2011; Li, 2011), analyst coverage (Yu, 2008), regulatory environment (La Porta et al., 2000), accounting transparency, and auditing effectiveness, etc. The regression residual may reflect the findings of Boone et al. (2007) that board size and independence increase as firms grow 
and diversify over time, effects which cannot be captured in time-invariant fixed effects. Finally, we observe that including manager and firm fixed effects changes the sign on leverage from positive to negative, suggesting that leverage and board monitoring are substitutes rather than complements in production.

\subsection{Board size}

The base specification (Model (1), Panel A, Table 7) is a pooled OLS regression, without firm or manager fixed effects (FE), which is based on the explanatory variables in Linck, Netter, and Young (2008, Table 4, Column 1), plus selected observable managerial attributes and year fixed effects. The dependent variable is the number of directors on the board. Benchmark adjusted $\mathrm{R}^{2}$ is 0.39 (Model (1), Panel A, Table 6). Adding firm fixed effects increases adjusted $\mathrm{R}^{2}$ to 0.79 (Model (2)), while manager fixed effects boosts adjusted $\mathrm{R}^{2}$ to 0.78 (Model (3)). Model (4) includes both firm and manager fixed effects to yield adjusted $R^{2}=0.80$.

Column B2 of Figure 7 and Panel B of Table 7 indicate that, when normalized by variation of board size explained by the model, the five classes of variables (observable firm attributes, observable manager attributes, firm fixed effects, manager fixed effects, and year fixed effects) contribute $9.8 \%, 5.0 \%, 30.8 \%, 52.5 \%$, and $1.8 \%$ of model $\mathrm{R}^{2}$. Including manager and firm fixed effects reduces the magnitude and significance of the coefficients on CEO age and R\&D intensity.

\subsection{Leadership structure: CEO duality}

The representative specification (Model (1), Panel A, Table 8) is a pooled logistic regression, without firm or manager fixed effects (FE), which is based on the explanatory variables in Linck, Netter, and Young (2008, Table 4, Column 3), plus selected observable managerial attributes. The dependent variable is the logit-transformed 
indicator variable that takes the value of 1 if the CEO and chairman positions are combined in one individual, and the value 0 otherwise. Benchmark adjusted $\mathrm{R}^{2}$ is 0.08 . Relative to the results reported to this point, fixed effects yield a larger improvement in fit (adjusted for degrees of freedom). Adding firm fixed effects increases adjusted $\mathrm{R}^{2}$ to 0 . 62 (Model (2)), while manager fixed effects boosts adjusted $\mathrm{R}^{2}$ to 0.65 (Model (3)). Model (4) includes both firm and manager fixed effects to yield adjusted $\mathrm{R}^{2}=0.68$.

Because of the nonlinearity in the logistic function, it is unclear how to generate the analysis of composition of fit. Thus, we re-estimate a simple linear version of Model (4). [Of course, while Model (5) includes both firm and manager fixed effects, it suffers from the defects that motivate the use of logit in the first place.] Column B3 of Figure 1 and Panel $\mathrm{B}$ of Table 8 indicate that, when normalized by variation of CEO duality explained by the model, the five classes of variables (observable firm attributes, observable manager attributes, firm fixed effects, manager fixed effects, and year fixed effects) contribute $9.2 \%, 0.8 \%, 31.1 \%, 55.9 \%$, and $3.1 \%$ of model R-squared.

A CEO who consistently performs well will be rewarded with the chairman position. Other determinants may be manager's reputation, credibility, charisma, and vision, all of which are typically hard to quantify. On the firm side, board leadership may depend on organizational structure and firm-specific restrictions and policies.

\section{Corporate Control}

We consider the correlates of the likelihood of a company making a control bid, receiving a control bid, and putting in place an antitakeover device. The primary specifications are probit. Like the logit model for leadership structure, however, decomposition of fit requires that we also estimate a simple linear probability model. 


\subsection{Propensity to bid}

The dependent variable is one if the firm announces a bid in year $t$ and zero otherwise. The benchmark specification is a probit regression, without firm or manager fixed effects, which is based on the explanatory variables in Harford (1999, Table III, Column 3), plus selected observable managerial attributes. Benchmark adjusted $\mathrm{R}^{2}$ is quite low at 0.12 (Model (1), Panel A, Table 9). Adding firm fixed effects increases adjusted $\mathrm{R}^{2}$ to 0.55 , while manager fixed effects boosts adjusted $\mathrm{R}^{2}$ to 0.56 . Model (4) includes both firm and manager fixed effects to yield adjusted $\mathrm{R}^{2}=0.59$.

The linear probability model (LPM) is Model (5). Column MA1 of Figure 1 and Panel B of Table 9 indicate that, when normalized by variation of propensity to bid explained by the model, the five classes of variables (observable firm attributes, observable manager attributes, firm fixed effects, manager fixed effects, and year fixed effects) contribute $4.6 \%, 0.6 \%, 36.1 \%, 57.9 \%$, and $0.8 \%$ of model R-squared. ${ }^{5}$ Firm level attributes such as cross-firm social connections (Ishii and Xuan, 2010) and organizational form (e.g., conglomerate or single-segment firms, per Maksimovic and Phillips, 2008) can affect acquisition propensity. As for managers, Malmendier and Tate (2008) show that the odds of making an acquisition are 65\% higher under overconfident CEOs. Note that both "empire-building" and "overconfidence" may lead to excessive acquisitiveness. The difference is that the former is a firm-level agency problem while the latter is manager specific personality. Overconfident managers believe that they are acting in the interest of shareholders. If so, the standard incentive contracts, as controlled for in the regression, are unlikely to correct their sub-optimal decisions.

\footnotetext{
${ }^{5}$ Manager fixed effects are prominent in this specification. This is consistent with Malmendier and Tate (2005), who suggest that (in bidder regressions) the manager fixed effect could represent CEO overconfidence.
} 
The large residual portion may reflect industry life-cycle (Maksimovic and Phillips, 2008) or industry shocks that Mitchell and Mulherin (1996) and Mulherin and Boone (2000) show to be significantly related to M\&A activity.

Comparing Model (4) with Model (1), the primary change due to the addition of firm and manager fixed effects is that the coefficient on the price-to-earnings ratio changes from significantly positive to significantly negative.

\subsection{Propensity to be a target}

The dependent variable is 1 if the firm is announced to be a target of a successful tender offer, merger proposal, or merger agreement in year $t$ and 0 otherwise. The benchmark specification is a probit regression, without firm or manager fixed effects, which is based on the explanatory variables in Comment and Schwert (1995, Table 3, Column 1), plus selected observable managerial attributes. Again, benchmark adjusted

$\mathrm{R}^{2}$ is quite low at 0.07 (Model (1), Panel A, Table 10). Adding firm fixed effects increases adjusted $\mathrm{R}^{2}$ to 0.56 , while manager fixed effects boosts adjusted $\mathrm{R}^{2}$ to 0.63 . Including both firm and manager fixed effects yields adjusted $\mathrm{R}^{2}=0.63$ (Model (4)).

The linear probability model is Model (5). Column MA2 of Figure 1 and Panel B of Table 10 indicate that observable firm attributes, observable manager attributes, firm fixed effects, manager fixed effects, and year fixed effects contribute $0.8 \%, 0.6 \%, 32.7 \%$, $62.3 \%$, and $0.6 \%$ of model R-squared, respectively. Adding both fixed effects makes insignificant the coefficients on firm size and prior abnormal return.

\subsection{Poison pill adoption}

The representative specification is a probit regression, without firm or manager fixed effects, which is based on the explanatory variables in Comment and Schwert (1995, Table 3, Column 4), plus selected observable managerial attributes. The dependent 
variable is one if the firm adopts poison pill in year $\mathrm{t}$ and zero otherwise. Fixed effects are important. Benchmark adjusted $\mathrm{R}^{2}$ is quite low at 0.07 (Model (1), Panel A, Table 11). Adding firm fixed effects increases adjusted $R^{2}$ to 0.88 (Model (2)), while manager fixed effects boosts adjusted $\mathrm{R}^{2}$ to 0.89 (Model (3)). Including both firm and manager fixed effects yields adjusted $\mathrm{R}^{2}=0.91$.

The linear probability model is Model (5). Column MA3 of Figure 1 and Panel B of Table 11 indicate that observable manager attributes, firm fixed effects, manager fixed effects, and year fixed effects contribute $1.7 \%, 0.2 \%, 57.2 \%, 40.6 \%$, and $0.2 \%$ of model R-squared, respectively.

Comparing probit Models (1) and (4), adding both fixed effects changes the coefficients on a number of important variables. The coefficient on each of the controlshares-law dummy, price-to-earnings ratio, firm size, and CEO indicator all change from significantly positive to significantly negative. The coefficient on market-to-book changes from significantly positive to insignificant and close to zero. These results suggest that the omitted variables problem is likely to be present in models examining the use of antitakeover devices.

\section{Financial Policy}

Capital structure has been a topic of significant interest since the beginnings of academic finance. Numerous recent empirical contributions would be appropriate as for us to set forward as the benchmark model. We base the leverage results below on specifications from Lemmon, Roberts, and Zender (2008), the reason being in part that they also suggest that firm fixed effects are important, particularly insofar as the fixed 
effects capture unobserved time-invariant factors that generate surprisingly stable capital structures.

\subsection{Book leverage}

The benchmark specification is a pooled OLS regression, without firm or manager fixed effects, which is based on the explanatory variables in Lemmon, Roberts, and Zender (2008, Table II, Panel A, Column 3), plus selected observable managerial attributes. The dependent variable is total debt scaled by firm assets. Benchmark adjusted $\mathrm{R}^{2}$ is 0.23 (Model (1), Panel A, Table 12). Adding firm fixed effects increases adjusted $\mathrm{R}^{2}$ to 0.67 (Model (2)), while manager fixed effects boosts adjusted $\mathrm{R}^{2}$ to 0.71 (Model (3)). Model (4) includes both firm and manager fixed effects to yield adjusted $\mathrm{R}^{2}$ $=0.74$.

As Panel B of Table 12 indicates, when normalized by variation of book leverage explained by the model, observable firm attributes, observable manager attributes, firm fixed effects, manager fixed effects, and year fixed effects, contribute $10.8 \%, 0.7 \%$, $62.5 \%, 25.6 \%$, and $0.5 \%$ of model R-squared. Column F1 in Figure 1 represents graphically these components of variation.

These results are consistent with the results and conclusions of Lemmon, Roberts, and Zender (2008). They find that corporate capital structures are stable over long periods of time and that this feature of the leverage data-generating process is present after controlling for firm entry and exit and for previously identified determinants of capital structure. Overall, they show that much of the variation in capital structure is time-invariant and that much of that variation is not explained by existing empirical specifications. This is consistent with Parsons and Titman (2008) and Graham and Leary 
(2011) who suggest more work is needed to identify what is captured in firm fixed effects but are missing from our models.

Compare Models (1) and (4) to discern the primary changes in empirical results from including manager and firm fixed effects. The coefficients on log (sales) and the dividend payer dummy (and manager tenure) change from positive (negative) and significant to negligible and insignificant.

\subsection{Market leverage}

The dependent variable is total debt scaled by the sum of total debt and market equity. The baseline specification is a pooled OLS regression, without firm or manager fixed effects, which is based on the explanatory variables in Lemmon, Roberts, and Zender (2008, Table II, Panel A, Column 6), plus selected observable managerial attributes. Benchmark adjusted $\mathrm{R}^{2}$ is 0.39 (Model (1), Panel A, Table 13). Adding firm fixed effects increases adjusted $\mathrm{R}^{2}$ to 0.77 , while manager fixed effects boosts adjusted $\mathrm{R}^{2}$ to 0.76 . Model (4) includes both firm and manager fixed effects to yield adjusted $\mathrm{R}^{2}=$ 0.79 .

Panel B of Table 13 indicates that, when normalized by variation of market leverage explained by the model, observable firm attributes, observable manager attributes, firm fixed effects, manager fixed effects, and year fixed effects, contribute $22.5 \%, 0.1 \%, 51.6 \%, 24.6 \%$, and $1.2 \%$ of model R-squared. Column F2 in Figure 1 represents graphically these components of variation.

These results and those for book leverage are consistent with the strong explanatory power for firm fixed effects reported in Lemmon, Roberts, and Zender (2008). Nonetheless, managerial fixed effects also represent a significant component of variation in both book and market leverage explained, which is consistent with the notion 
that managerial characteristics, such as risk aversion, affect corporate financial policy (see Cronqvist, Makhija, and Yonker, 2010). Moreover, overconfident managers exhibit strong debt conservatism and pecking-order preferences (Malmendier, Tate, and Yan, 2011). Furthermore, Berger, Ofek, and Yermack (1997) show managers who have more control would keep leverage ratio low. Other important factors are likely to be cost of borrowing as determined by credit risk, relationships with lenders, and the implicit interest rate. In addition, firm culture will keep leverage and cash holding persistent over time (Cronqvist, Low, and Nilsson, 2007).

Comparing Models (1) and (4), the primary changes in empirical results from including manager and firm fixed effects are that the dividend payer dummy changes from small and insignificant to positive and insignificant, while significant coefficients on manager tenure, the $\mathrm{CEO}$ indicator, and the board seat indicator become small and insignificant.

\subsection{Cash holdings}

The baseline specification is a pooled OLS regression, without firm or manager fixed effects, which is based on the explanatory variables in Harford, Mansi, and Maxwell (2008, Table 3, Column 1), plus selected observable managerial attributes. The natural logarithm of the cash to sales ratio is the dependent variable. Benchmark adjusted $\mathrm{R}^{2}$ is fairly large at 0.41 (Model (1), Panel A, Table 14). Adding firm fixed effects yields adjusted $R^{2}$ of 0.80 , manager fixed effects alone delivers adjusted $R^{2}$ of 0.80 , and using both gives adjusted $\mathrm{R}^{2}=0.82$.

Panel B of Table 14 indicates that observable firm attributes, observable manager attributes, firm fixed effects, manager fixed effects, and year fixed effects, contribute 
17.0\%, 0.80\%, 51.0\%, 28.8\%, and 2.4\% of model R-squared. ${ }^{6}$ Column F3 in Figure 1 represents graphically these components of normalized variation. Like book and market leverage, firm observables and fixed effects dominate manager observable and fixed effects.

Frank and Goyal (2009) show industry median leverage is an important correlate, acting as a proxy for company specific intangibility, regulation, stock variance, and uniqueness. Obviously, this proxy is so noisy that the firm fixed effects may capture a large portion of these factors.

Comparing Models (1) and (4), including manager and firm fixed effects alters parameter estimates and inference in numerous cases. Significant coefficients in Model (1) that are insignificant in Model (4) with both fixed effects are the director indicator, G index, cash flow volatility, and market-to-book. Variables that become significant are firm size (-), R\&D intensity (-), and manager age (-). Omitted variables and other endogeneity problems may be a significant difficulty in the analysis of cash holdings.

\section{Payout Policy}

Like capital structure, the characteristics, determinants, and implications of dividend policy comprise one of the original areas of inquiry in finance. Again, there are numerous candidates for the benchmark specification. We select DeAngelo, DeAngelo, and Stulz (2006) as the source of our baseline specification.

\subsection{Dividend Payout Ratio}

\footnotetext{
${ }^{6}$ According to Bates, Kahle, and Stulz (2009), cash holdings are determined by cash flow risk rather than agency conflicts. This would explain why firm fixed effects dominate manager fixed effects.
} 
The dependent variable is an indicator variable that takes the value of 1 if the firm pays out one or more dividends in the fiscal year, and 0 otherwise. The benchmark specification is a pooled logistic regression, without firm or manager fixed effects, which is based on the explanatory variables in DeAngelo, DeAngelo, Stulz (2006, Table 3, Column 1), plus selected observable managerial attributes. Benchmark adjusted $\mathrm{R}^{2}$ is 0.34 (Model (1), Panel A, Table 15). Adding firm fixed effects increases adjusted $\mathrm{R}^{2}$ to 0.93, while manager fixed effects boosts adjusted $\mathrm{R}^{2}$ to 0.92 . Model (4) includes both firm and manager fixed effects to yield adjusted $R^{2}=0.94$.

Our dividend payout variable is dichotomous, so we estimate the linear probability model using the explanatory variables from the logit specifications (see Model (5), Panel A). Panel B of Table 15 indicates that, when normalized by variation of dividend payout explained by the model, observable firm attributes, observable manager attributes, firm fixed effects, manager fixed effects, and year fixed effects, contribute $3.4 \%, 0.2 \%, 68.6 \%, 27.1 \%$, and $0.7 \%$ of model R-squared. Column D1 in Figure 1 represents graphically these components of variation. Like financial policy, firm characteristics and firm fixed effects dominate those for managers.

Firm fixed effects may reflect market imperfections such as agency problems, asymmetric information, and taxes (e.g., Myers and Majluf, 1984). Firm culture can give rise to stable dividend policy through time (Cronqvist, Low, and Nilsson, 2007). The empirical evidence, however, is inconclusive and much of the variation across firms remains unexplained (see Allen and Michaely, 2003). At the manager level, overconfidence (Deshmukh, Goel, and Howe, 2010) and political ideology (Hutton, Jiang, and Kumar, 2010) potentially are related to the propensity to pay dividends and, thus, would be captured by manager fixed effects. Comparing Models (1) and (4), the primary 
changes in empirical results from including manager and firm fixed effects are that the coefficients on both the ratio of retained earnings to total common equity and manager age change from significantly positive to insignificant and the coefficients on the ratio of total common equity to total assets and market-to-book change from significantly negative to significantly positive.

\section{Investment Policy}

Investment policy can focus on relatively tangible versus intangible assets, with the former perceived as less risky than the latter. Thus, we examine capital expenditures versus expenditures on $R \& D$ and, ultimately, the determinants of firm risk.

\subsection{Capital expenditures}

The dependent variable is capital expenditure, net of sales of property, plant, and equipment, scaled by total assets. The representative specification is a pooled OLS regression, without firm or manager fixed effects, which is based on the explanatory variables in Coles, Daniel, and Naveen (2006, Table 3, Panel B, Column 1) plus selected observable managerial attributes. Benchmark adjusted $\mathrm{R}^{2}$ is quite small, with value equal to 0.08 (Model (1), Panel A, Table 16). Adding firm fixed effects increases adjusted $\mathrm{R}^{2}$ to 0.62 , while manager fixed effects boosts adjusted $\mathrm{R}^{2}$ to 0.61 . Model (4) includes both firm and manager fixed effects to yield adjusted $R^{2}=0.63$.

As Panel B of Table 16 indicates, when normalized by variation of capital expenditure explained by the model, observable firm attributes, observable manager attributes, firm fixed effects, manager fixed effects, and year fixed effects, contribute $10.7 \%, 0.1 \%, 47.3 \%, 41.6 \%$, and $0.4 \%$ of model R-squared. Column I1 in Figure 1 represents graphically these components of variation. The relative power of manager 
fixed effects versus manager observables is striking. This suggests that developing models that isolate relevant manager characteristics and developing good proxies for those attributes would be good strategies.

Theories define firm culture as well-established shared beliefs and organizational preferences (e.g., Kreps, 1990; Lazear, 1995; Hermalin, 2001). Cronqvist, Low, and Nilsson (2007) find that firm culture matters for investment policy, such as capital expenditure and R\&D investment, and that firm culture is not necessarily dependent on the particular CEO in place. Interestingly, literature shows that managerial bias (BenDavid, Graham, Harvey, 2010), overconfidence, personal education, employment history (scientific vs. financial) (Malmendier and Tate, 2005), and political ideology (Hutton, Jiang, and Kumar, 2010) also have explanatory power for investment policies

Compare Models (1) and (4) to discern the primary changes in empirical results from including manager and firm fixed effects. Inference changes for three variables that come immediately to mind as likely to be important for capital expenditures, specifically compensation vega, surplus cash, and $\log ($ sales $)$.

\section{$11.2 R \& D$ intensity}

The dependent variable is research and development expenditure scaled by assets, with missing values for R\&D set to zero. The benchmark specification is a pooled OLS regression, without firm or manager fixed effects, which is based on the explanatory variables in Coles, Daniel, and Naveen (2006, Table 3, Panel A, Column 1), plus selected observable managerial attributes.

Note that benchmark adjusted $\mathrm{R}^{2}$ is substantially higher than for capital expenditures, with value equal to 0.28 (Model (1), Panel A, Table 17). Adding firm fixed effects increases adjusted $\mathrm{R}^{2}$ to 0.77 , manager fixed effects boosts adjusted $\mathrm{R}^{2}$ to 0.78 , 
and including both firm and manager fixed effects yields adjusted $\mathrm{R}^{2}=0.80($ Model (4)). As Panel B of Table 17 indicates, when normalized by variation of R\&D explained by the model, observable firm attributes, observable manager attributes, firm fixed effects, manager fixed effects, and year fixed effects contribute $12.9 \%, 0.1 \%, 51.8 \%, 35.2 \%$, and $0.1 \%$ of model R-squared. Column $\mathrm{I} 2$ in Figure 1 represents graphically these components of variation. Relative to the results for capital expenditures, firm attributes, those observed and unobserved, are more important for R\&D intensity than managerial attributes.

Giroud and Mueller (2011) show product market competition should be considered in determining the relation between governance and R\&D, CAPEX, etc. This may be absorbed in firm fixed effects. Nonetheless, their R-squared doesn't improve much when including proxies for product market competition. Other factors absorbed in firm fixed effects may include industry- or firm-specific technology, productivity, and human capital.

Compare Models (1) and (4) to discern the primary changes in empirical results from including manager and firm fixed effects. The three significant compensation variables, vega, delta, and cash compensation, all become insignificant after firm and manager fixed effects are included. Inference also is altered for book leverage, manager age, and the director indicator.

\subsection{Firm risk}

The dependent variable is the one-year standard deviation of daily stock returns. The representative specification is a pooled OLS regression, without firm or manager fixed effects, which is based on the explanatory variables in Coles, Daniel, and Naveen (2006, Table 9, Column 1), plus selected observable managerial attributes. Benchmark 
adjusted $\mathrm{R}^{2}$ is among the highest among all subfields examined in this paper, with value equal to 0.48 (Model (1), Panel A, Table 18). Adding firm or manager fixed effects increases adjusted $\mathrm{R}^{2}$ to 0.81 , while including both firm and manager fixed effects yields adjusted $\mathrm{R}^{2}=0.83$

As Panel B of Table 18 indicates, when normalized by variation of firm risk explained by the model, observable firm attributes, observable manager attributes, firm fixed effects, manager fixed effects, and year fixed effects, respectively, contribute $8.0 \%$, $1.9 \%, 45.2 \%, 17.6 \%$, and $27.7 \%$ of model R-squared. Column I3 in Figure 1 represents graphically these components of variation. These results are noteworthy insofar that year fixed effects exhibit far and away the most power here as compared to all other models we estimate.

It is intuitive that stock return volatility is largely determined by firm specific fundamentals, such as line of business. Nonetheless, research also shows that managerial narcissism (Chatterjee and Hambrick, 2007), ego, bias, experience (Finkelstein and Hambrick, 1996), and power (Adams, Almeida, and Ferreira, 2005) also affect risktaking and volatility.

Comparing Models (1) and (4), including manager and firm fixed effects changes the coefficient on cash compensation from insignificant to negative and significant, and vice versa for manager age and the director indicator. The coefficient on book leverage is significant in both models but switches from negative to positive.

\section{Diversification}

While the extent of product market diversification can be viewed as an element of investment policy, we consider it separately because of the large volume of literature on 
the topic. We employ two standard measures. The Herfindahl index is the sum of the squares of segment sales divided by the square of firm sales. The Herfindahl index increases in firm focus. We also use the natural $\log$ of the number of operating segments as reported in Compustat segment database. This measure decreases in firm focus.

\subsection{Herfindahl index}

The representative specification is a pooled OLS regression, without firm or manager fixed effects, which is based on the explanatory variables in Coles, Daniel, and Naveen (2006, Table 4, Panel A, Column 1), plus selected observable managerial attributes. Benchmark adjusted $\mathrm{R}^{2}$ is 0.16 (Model (1), Panel A, Table 19). Adding firm or manager fixed effects increases adjusted $\mathrm{R}^{2}$ to 0.73 and 0.75 , respectively, while including both firm and manager fixed effects yields adjusted $\mathrm{R}^{2}$ of 0.79 .

Panel B of Table 19 indicates that, when normalized by the variation of the Herfindahl index explained by the model, observable firm attributes, observable manager attributes, firm fixed effects, manager fixed effects, and year fixed effects, respectively, contribute $13.1 \%, 0.1 \%, 45.7 \%, 37.5 \%$, and $3.5 \%$ of model R-squared. Column I4 in Figure 1 represents graphically these components of variation.

A firm may enter a new industry if the firm's existing expertise and technology are easy to apply in this industry. Other possible determinants are the company's organizational structure and market position. Furthermore, Malmendier and Tate (2008) find overconfident CEOs make more diversifying acquisitions. Industry experience and diversity of the management team are other candidates for the explanatory power of manager fixed effects.

Comparing Models (1) and (4), including manager and firm fixed effects changes inference on a number of variables. The dividend cut dummy, prior stock return, 
compensation vega, and manager age all change from significantly negative to insignificant. Sign changes occur on cash compensation and sales growth.

\section{$12.2 \operatorname{Ln}($ Number of segments)}

The baseline specification is a pooled OLS regression, without firm or manager fixed effects, which is based on the explanatory variables in Coles, Daniel, and Naveen (2006, Table 4, Panel B, Column 1), plus selected observable managerial attributes. Benchmark adjusted $\mathrm{R}^{2}$ is a modest 0.21 (Model (1), Panel A, Table 20). Adding firm fixed effects increases adjusted $\mathrm{R}^{2}$ to 0.73 , manager fixed effects boosts adjusted $\mathrm{R}^{2}$ to 0.75 , and including both firm and manager fixed effects yields adjusted $\mathrm{R}^{2}=0.79$ (Model (4)). As Panel B of Table 20 indicates, when normalized by variation of $\ln$ (segments) explained by the model, observable firm attributes, observable manager attributes, firm fixed effects, manager fixed effects, and year fixed effects contribute $11.7 \%, 0.5 \%$, 44.6\%, 34.9\%, and $8.3 \%$ of model R-squared. ${ }^{7}$ Column I5 in Figure 1 represents graphically these components of variation.

Comparing Models (1) and (4) reveals a nontrivial number of changes in inference arising from including manager and firm fixed effects. Fixed effects alter inference for manager tenure, the CEO turnover indicator, the dividend cut indicator, sales growth, stock return, and the executive compensation variables.

\section{Firm Performance}

\footnotetext{
${ }^{7}$ Denis, Denis, and Sarin (1997) note that diversification is associated with external corporate control threats, financial distress, and management turnover. These factors are likely to affect the relative importance of firm and manager fixed effects.
} 
The study of the determinants of firm value and performance has been a persistent and significant segment of the literature. ${ }^{8}$ The performance measures we use as dependent variables are: Tobin's Q, the ratio of the market value of the firm's securities to the replacement cost of its tangible assets; and ROA, the ratio of net income to the book value of the firm's total assets.

\subsection{Tobin's $Q$}

The representative specification is a pooled OLS regression, without firm or manager fixed effects, which is based on the explanatory variables in Mehran (1995, Table 4, Panel A, Column 4), plus selected observable managerial attributes. Benchmark adjusted $\mathrm{R}^{2}$ is 0.24 (Model (1), Panel A, Table 21). Adding firm fixed effects increases adjusted $\mathrm{R}^{2}$ to 0.70 , manager fixed effects boost adjusted $\mathrm{R}^{2}$ to 0.71 , and including both firm and manager fixed effects yields adjusted $\mathrm{R}^{2}=0.75$ (Model (4)). As Panel B of Table 21 indicates, when normalized by variation of Tobin's Q explained by the model, observable firm attributes, observable manager attributes, firm fixed effects, manager fixed effects, and year fixed effects contribute $5.5 \%, 0.4 \%, 43.6 \%, 48.1 \%$, and $2.4 \%$ of model R-squared. Column P1 in Figure 1 represents graphically these components of variation. These figures are most notable in that unobserved manager attributes represent such a large proportion of explained variation.

Managerial ability and risk aversion are obvious potential sources of the explanatory power of manager fixed effects. Other possibilities are "integrity" (Erhard, Jensen, and Zaffron, 2008), reputation (Chemmanur and Paeglis, 2005), leadership qualities, vision, and professional network. Manager's extra-curricular activities, though

\footnotetext{
${ }^{8}$ Influential examples include Morck, Shleifer, and Vishny (1988) and McConnell and Servaes (1990) for Tobin's Q. See Coles, Lemmon, and Meschke (2011) for a discussion of performance-on-structure regressions.
} 
seemingly irrelevant, may have connection with performance, such as home purchase (Liu and Yermack, 2007), public awards (Malmendier and Tate, 2005; 2009), marriage, children, family illness (Bennedsen et al., 2007). Comparing Models (1) and (4) reveals a nontrivial number of sign changes in important coefficients. From significantly positive to significantly negative are the coefficients on manager wealth-performance sensitivity, prior relative operating performance, and firm size (as measured by $\log ($ assets)). Board independence changes from significantly negative to significantly positive.

\subsection{Return on assets}

The baseline specification is a pooled OLS regression, without firm or manager fixed effects, which is based on the explanatory variables in Mehran (1995, Table 4, Panel B, Column 4), plus selected observable managerial attributes. Benchmark adjusted $\mathrm{R}^{2}$ is 0.17 (Model (1), Panel A, Table 22). Adding firm fixed effects increases adjusted $\mathrm{R}^{2}$ to 0.72 , manager fixed effects boosts adjusted $\mathrm{R}^{2}$ to 0.73 , and including both firm and manager fixed effects yields adjusted $\mathrm{R}^{2}=0.76($ Model (4)).

As Panel B of Table 22 indicates, when normalized by variation of ROA explained by the model, observable firm attributes, observable manager attributes, firm fixed effects, manager fixed effects, and year fixed effects contribute $14.4 \%, 1.5 \%$, 52.0\%, 29.6\%, and 2.5\% of model R-squared. Column P2 in Figure 1 represents graphically these components of variation. These figures are notable in comparison to the results above on Tobin's Q, because relative explanatory power shifts towards unobserved and observed firm attributes instead of manager characteristics.

Comparing Models (1) and (4) reveals a few important alterations in inference. The coefficients on board independence and scaled inventory plus PPE are no longer positive and significant but become insignificant. 


\section{Additional Discussion}

One obvious possibility is that the low explanatory share of explained variation for observed firm and manager characteristics and the poor overall fit (large residual variation) arise from nonstationarity through time of the estimated cross-sectional coefficients on observed manager and firm characteristics. To test this notion, we reestimate each of the 20 empirical specifications including a sixth class of variable, namely the interaction of three or four of the primary observed manager and firm characteristics predicted by theory to be important with time indicators for each year (except one). This allows the cross-sectional parameters for each of these primary observables to vary through time.

In all 20 cases the class of interactive variables typically provides less than $2 \%$ of explained variation of the dependent variable. This class of variables subsumes very little of the explained variation of the other five classes of independent variables. Nonstationarity of the cross-sectional coefficients on observed manager and firm characteristics is not an explanation for poor overall fit and is not an explanation for the low explanatory power of observed manager and firm characteristics.

\section{Conclusion}

To empirically gauge the state of progress in empirical corporate finance, we apply the connected-groups approach of Abowd, Karmarz, and Margolis (1999) to identify and estimate the role of observed and unobserved firm- and manager-specific characteristics in determining primary features of corporate governance, financial policy, payout policy, investment policy, and performance. The results allow us to assess the 
extent of empirical progress in the various subfields in empirical corporate finance. We consider a broad range of subfields. They are: executive compensation (level, wealthperformance sensitivity, and risk incentives); board structure (composition, size, and leadership structure); corporate control (usage of antitakeover provisions, propensity to be a merger target or bidder); payout policy (dividend payout propensity); financial policy (book and market leverage, cash balances); investment policy (R\&D intensity, capital expenditure, firm focus, and firm risk); and firm performance (ROA, Tobin's Q).

Table 1 and Figure 1 summarize our results. Measured by fit, some subfields are more successful than others. Estimated specifications without firm and manager fixed effects do poorly in explaining variation in CEO duality, corporate control variables, and capital expenditures, and best in explaining executive pay level, board size, market leverage, corporate cash holdings, and firm risk.

When fit based on observable manager and firm characteristics is poor, our analysis suggests ways forward for theory and empirics. Including manager and firm fixed effects, along with firm and manager observables, delivers the best fit for dividend payout, the propensity to adopt antitakeover defenses, firm risk, board size, and firm focus. In terms of source of fit, unobserved manager attributes deliver a high proportion of explained variation in the dependent variable for executive wealth-performance sensitivity, board independence, board size, and sensitivity of expected executive compensation to firm risk. A significant portion of what we know we do not know is related to time-invariant attributes of managers. In contrast, unobserved firm attributes provide a high proportion of variation explained for dividend payout, antitakeover defenses, book and market leverage, and corporate cash holdings. For these aspects of organization structure and policy, a significant portion of what we know we do not know 
is related to time-invariant attributes of firms. That is, our results suggest where empiricists would look for better proxies for what current theory identifies as important and where theorists could focus in building new models that encompass economic forces not contained in existing models.

Finally, we assess the relevance of omitted variables and endogeneity for conventional empirical designs in the various subfields. These problems appear to be severe in some areas.

Figure 2 represents our attempt to place this paper in the literature. The figure classifies research into four categories, using the topic of executive compensation as an example. From left to right, the papers become less theoretical and more empirical. This paper is located on the far right of the figure. This is a purely empirical exercise, meant nonetheless to suggest to empiricists and theorists where there are likely to be productive research opportunities in empirical corporate finance. 


\section{Appendix (Variable Definitions)}

Managerial Attributes:

\begin{tabular}{ll}
\hline Variable & \multicolumn{1}{c}{ Definition } \\
\hline Age & Manager's age in years \\
Tenure & Number of years of continuous employment with a firm \\
Female & A dummy variable with 1 for female and 0 for male \\
CEO & A dummy variable with 1 if the executive served as the CEO of the company \\
& for all or most of the indicated fiscal year and 0 otherwise \\
Director & A dummy variable with 1 if the executive served as a director of the \\
& company and 0 otherwise \\
Mover & A dummy variable with 1 for managers who switched firm in the sample \\
& period and 0 for those who did not
\end{tabular}

Variables from Coles, Daniel, and Naveen (2006):

\begin{tabular}{|c|c|}
\hline Variable & Definition \\
\hline Delta & The dollar change in the executive's wealth for a $1 \%$ change in stock price \\
\hline Vega & $\begin{array}{l}\text { The dollar change in the executive's wealth for a } 0.01 \text { change in standard } \\
\text { deviation of returns }\end{array}$ \\
\hline Market-to-book & $\begin{array}{l}\text { The ratio of the market value of equity item minus the book value of } \\
\text { equity plus the book value of assets to the book value of assets }\end{array}$ \\
\hline Firm risk & The standard deviation of one-year daily stock returns \\
\hline Log (Net Assets) & $\begin{array}{l}\text { The natural log of Net Assets, where Net Assets is calculated as total } \\
\text { assets less cash and short-term investments }\end{array}$ \\
\hline $\mathrm{R} \& \mathrm{D}$ & Research and development expenditure scaled by assets \\
\hline Surplus Cash & Amount of cash available to finance new projects, scaled by assets \\
\hline Board Independence & The number of independent outside directors divided by board size \\
\hline Institutional & The percentage of company's outstanding common shares held by \\
\hline Holdings & institutions \\
\hline ROA & $\begin{array}{l}\text { Return on assets, calculated as net income before extraordinary items and } \\
\text { discontinued operations divided by total assets }\end{array}$ \\
\hline PPE & Investment in property, plant, and equipment scaled by assets \\
\hline CAPEX & $\begin{array}{l}\text { Capital expenditure net of sales of property, plant, and equipment, scaled } \\
\text { by assets }\end{array}$ \\
\hline Leverage & Book debt divided by book assets. (i.e., book leverage) \\
\hline Sales growth & $\log \left(\right.$ Sales $_{t} /$ Sales $\left._{t-1}\right)$ \\
\hline Cash compensation & The sum of manager's salary and bonus. \\
\hline Stock Return & The stock return over the fiscal year. \\
\hline Herfindahl Index & The sum of the square of segment sales divided by the square of firm sales \\
\hline Dividend Cut & $\begin{array}{l}\text { A dummy variable with } 1 \text { if there is a reduction in annual dividend and } 0 \\
\text { otherwise }\end{array}$ \\
\hline CEO Turnover & A dummy variable with 1 if the CEO was replaced and 0 otherwise \\
\hline Ln(Segments) & $\begin{array}{l}\text { The natural log of the number of operating segments as reported in } \\
\text { Compustat segment database }\end{array}$ \\
\hline
\end{tabular}


Variables from Linck, Netter, and Yang (2008):

\begin{tabular}{|c|c|}
\hline Variable & Definition \\
\hline Board size & The number of directors on the board \\
\hline Board independence & The proportion of the board composed of non-executive directors \\
\hline Board leadership & $\begin{array}{l}\text { A dummy variable with } 1 \text { if the CEO is also the Chairman of the Board } \\
\text { and } 0 \text { otherwise, which is also referred to as combined leadership or CEO } \\
\text { duality }\end{array}$ \\
\hline LogMVE & The logarithm of market value of equity \\
\hline Debt & Total long-term debt over total assets \\
\hline LogSegments & The logarithm of number of business segments \\
\hline FirmAge & The number of years since the firm first appeared on CRSP \\
\hline MTB & The market-to-book ratio of equity \\
\hline $\mathrm{R} \& \mathrm{D}$ & $R \& D$ expenses over total assets \\
\hline RETSTD & $\begin{array}{l}\text { The standard deviation of the monthly stock return over the fiscal year } \\
\text { immediately in the preceding fiscal year }\end{array}$ \\
\hline CEO_Own & The percent of shares held by the CEO \\
\hline Director_Own & The average percent of firm's shares held by non-executive directors \\
\hline $\mathrm{FCF}$ & $\begin{array}{l}\text { Free cash flow (operating income before depreciation minus total income } \\
\text { taxes, change in deferred taxes, interest expense, preferred dividends, and } \\
\text { dividends on common stock) scaled by total assets }\end{array}$ \\
\hline Performance & $\begin{array}{l}\text { The average annual industry-adjusted earnings before interest and taxes } \\
\text { scaled by total assets over the two-year period preceding the proxy date }\end{array}$ \\
\hline Lag(CEO_Chair) & $\begin{array}{l}\text { A dummy variable with } 1 \text { if the } \mathrm{CEO} \text { is also the Chairman of the Board in } \\
\text { the previous period and } 0 \text { otherwise }\end{array}$ \\
\hline
\end{tabular}

Variables from Harford (1999):

\begin{tabular}{|c|c|}
\hline Variable & Definition \\
\hline Abnormal return & $\begin{array}{l}\text { The daily market-model abnormal return averaged over years } t-4 \text { through } t \text { - } \\
1\end{array}$ \\
\hline Sales growth & The average sales growth over years $t-4$ through $t-1$ \\
\hline $\begin{array}{l}\text { Noncash working } \\
\text { capital }\end{array}$ & $\begin{array}{l}\text { Net working capital (current assets - current liabilities) minus cash and } \\
\text { cash equivalents, normalized by total assets and averaged over years } t \text { - } 4 \\
\text { through } t-1\end{array}$ \\
\hline Leverage & $\begin{array}{l}\text { The ratio of book value of debt to market value of equity, averaged over } \\
\text { years } t-4 \text { to through } t-1\end{array}$ \\
\hline Market-to-book & $\begin{array}{l}\text { The ratio of market value of equity to book value of equity, averaged } \\
\text { over years } t-4 \text { through } t-1\end{array}$ \\
\hline Price-to-earnings & $\begin{array}{l}\text { The stock price divided by earnings per share, averaged over years } t-4 \\
\text { through } t-1 \text {. }\end{array}$ \\
\hline Size & The natural logarithm of total assets \\
\hline
\end{tabular}


Variables from Comment and Schwert (1995):

\begin{tabular}{ll}
\hline Variable & \multicolumn{1}{c}{ Definition } \\
\hline Abnormal return & $\begin{array}{l}\text { The daily market-model abnormal return averaged over years } t-4 \text { through } t-1 \\
\text { Sales growth }\end{array}$ \\
$\begin{array}{l}\text { The average sales growth over years } t-4 \text { through } t-1 \\
\text { The ratio of net liquid assets to total assets, averaged over years } t \text { - } 4 \text { through } \\
t-1\end{array}$ \\
$\begin{array}{l}\text { The ratio of debt to equity, averaged over years } t-4 \text { to through } t-1 \\
\text { Control share law }\end{array}$ & $\begin{array}{l}\text { A dummy variable with } 1 \text { if the control share law is effective for the state in } \\
\text { which the company is incorporated and } 0 \text { otherwise }\end{array}$ \\
$\begin{array}{l}\text { Business } \\
\text { combination law } \\
\text { Poison pill }\end{array}$ & $\begin{array}{l}\text { A dummy variable with } 1 \text { if the business combination law is effective for the } \\
\text { state in which the company is incorporated and } 0 \text { otherwise } \\
\text { A dummy variable with } 1 \text { if the firm has a shareholder rights plan in effect } \\
\text { and } 0 \text { otherwise }\end{array}$ \\
\hline
\end{tabular}

Variables from Lemmon, Roberts, and Zender (2008):

\begin{tabular}{|c|c|}
\hline Variable & Definition \\
\hline Book Leverage & Total debt scaled by book assets \\
\hline Market Leverage & Total debt scaled by the sum of total debt and market equity. \\
\hline Initial Leverage & $\begin{array}{l}\text { The first non-missing value for leverage in the Compustat from } 1980 \text { to } \\
2006\end{array}$ \\
\hline Profitability & Operating income before depreciation scaled by book assets \\
\hline Cash Flow & The standard deviation of historical operating income, requiring at least 3 \\
\hline Volatility & years of data \\
\hline Tangibility & Investment in property, plant, and equipment (PPE) scaled by book assets \\
\hline Dividend Payer & $\begin{array}{l}\text { A dummy variable with } 1 \text { if the firm pays out dividend in the fiscal year and } \\
0 \text { otherwise }\end{array}$ \\
\hline
\end{tabular}

Variables from Harford, Mansi, and Maxwell (2008):

\begin{tabular}{|c|c|}
\hline Variable & Definition \\
\hline Cash Holdings & The natural $\log$ of the cash/sales ratio \\
\hline Gindex & The Gompers, Ishii, and Metrick (2003) antitakeover index \\
\hline Inside Ownership & The equity ownership of the top five officers \\
\hline Pay Sensitivity & Managerial delta \\
\hline $\begin{array}{l}\text { Institutional } \\
\text { ownership }\end{array}$ & The percentage of intuitional equity holdings \\
\hline Size & The natural $\log$ of total assets \\
\hline Leverage & The ratio of total debt (short- and long-term debt) to assets \\
\hline Cash flow & $\begin{array}{l}\text { Earnings after interest, dividend, and taxes, but before depreciation, } \\
\text { divided by assets }\end{array}$ \\
\hline Working capital & $\begin{array}{l}\text { The ratio of current assets net of cash minus current liabilities divided by } \\
\text { assets }\end{array}$ \\
\hline CF Volatility & The standard deviation of cash flows for the past five years \\
\hline $\mathrm{R} \& \mathrm{D}$ & The ratio of research and development to sales \\
\hline CapEx & The ratio of capital expenditures to net assets \\
\hline
\end{tabular}


Acquisition

Dividend indicator

Bond indicator
The ratio of acquisition to sales

A dummy variable with 1 if the firm pays out dividend in the fiscal year and 0 otherwise

A dummy variable with 1 if the firm has long-term S\&P rating and 0 otherwise

Variables from DeAngelo, DeAngelo, and Stulz (2006):

\begin{tabular}{ll}
\hline Variable & \multicolumn{1}{c}{ Definition } \\
\hline Dividend payout & $\begin{array}{l}\text { A dummy variable with } 1 \text { if the firm pays out dividend in the fiscal year } \\
\text { and } 0 \text { otherwise }\end{array}$ \\
RE/TE & The ratio of earned equity (retained earnings) to total common equity \\
TE/TA & The ratio of total common equity to total assets \\
Sales growth & Log $($ Sales $/$ Salest -1$)$
\end{tabular}

Variables from Mehran (1995):

\begin{tabular}{ll}
\hline Variable & \multicolumn{1}{c}{ Definition } \\
\hline Tobin's Q & $\begin{array}{l}\text { The ratio of the market value of the firm's securities to the replacement } \\
\text { cost of its tangible assets } \\
\text { The ratio of net income to the book value of the firm's total assets } \\
\text { ROA } \\
\text { \% of managers' } \\
\text { equity compensation } \\
\text { The ratio of the sum of the value of awards from grants of new stock } \\
\text { options, restricted stocks, phantom stocks, and performance shares to } \\
\text { total compensation } \\
\text { all outside }\end{array}$ \\
$\begin{array}{l}\text { The sum of the percentages of equity held by individual investors, } \\
\text { institutional investors, and corporations who own at least 5\% of the } \\
\text { common stock of the company }\end{array}$ \\
$\begin{array}{l}\text { The percentage of outside board directors who are neither top executives, } \\
\text { retired executives, or former executives of the company nor relatives of } \\
\text { the CEO }\end{array}$ \\
Mtd of \% change in \\
operating income
\end{tabular}$\quad$\begin{tabular}{l} 
Measured with annual data in the proceeding five years \\
\hline
\end{tabular}




\section{References}

Acharya, V., S. Myers, and R. Rajan, 2011, The internal governance of firms, Journal of Finance, 66-3, 689-720. fortheoming.

Abowd, J. M., F. Karmarz, and D. N. Margolis, 1999, High Wage Workers and High Wage Firms, Econometrica, 67-2, 251-333.

Adams, R.B., Almeida, H., Ferreira, D., 2005. Powerful CEOs and their impact on corporate performance. Review of Financial Studies. 18, 1403-1432.

Aggarwal, R., and A. Samwick, 1999. The other side of the tradeoff: the impact of risk on executive compensation. Journal of Political Economy 107, 65-105.

Aggarwal, R., and A. Samwick, 2003. Performance Incentives within Firms: The Effect of Managerial Responsibility. Journal of Finance 58, 1613-1649.

Allen, F. and R. Michaely, 2003, Payout policy, in George Constantinides, Milton Harris, and Rene Stulz, eds.: Handbooks of Economics, North-Holland, Amsterdam, The Netherlands.

Baker, M., Gompers, P., 2003. The determinants of board structure at the initial public offering. Journal of Law and Economics 46, 569-598.

Baliga, B.R., R.C. Moyer, R.S. Rao, 1996, CEO duality and firm performance: What's the fuss?. Strategic Management Journal 17, 41-53.

Bates, T. W., K. Kahle, and R. Stulz, 2009, Why Do U.S. Firms Hold So Much More Cash than They Used To?, Journal of Finance, 64-5, 1985-2021.

Ben-David, I., J.R. Graham, and C.R. Harvey, 2010, Managerial miscalibration, Working paper, Duke UniversityQuarterly Journal of Economics, 128-4, 1547-1584.

Bennedsen, M., K. M. Nielsen, F.Pérez-González, and D.Wolfenzon, 2007. Inside the family firm: the role of families in succession decisions and performance. Quarterly Journal of Economics, 122, 647-91.

Berger, P., Ofek, E., Yermack, D., 1997. Managerial entrenchment and capital structure decisions. Journal of Finance 52, 1411-1438.

Bergman, N., Jenter, D., 2007. Employee sentiment and stock option compensation. Journal of Financial Economics 84, 667-712.

Bertrand, M. and A. Schoar, 2003, Managing with Style: the Effect of Managers on Firm Policies, Quarterly Journal of Economics, 118-4, 1169-1208.

Bizjak, J., Brickley, J., Coles, J., 1993. Stock-based incentive compensation and investment behavior. Journal of Accounting and Economics 16, 349-372.

Boone, A., Field, L., Karpoff, J., Raheja, C., 2007. The determinants of corporate board size and composition: an empirical analysis. Journal of Financial Economics 85, 66-101.

Brickley, J. A., Coles, J. L., Jarrell, G., 1997. Leadership structure: separating the CEO and chairman of the board. Journal of Corporate Finance, 3, 189-220.

Brickley, J., J. L. Coles, and R. Terry, 1994, The Board of Directors and the Adoption of Poison Pills, Journal of Financial Economics 35, 371-390.

Byoun, S., 2008. When Do Firms Adjust Their Capital Structures toward Targets? The Journal of Finance 63, 3069-3096.

Byrd, J., and K. Hickman, 1992, Do outside directors monitor managers? Evidence from tender offer bids, Journal of Financial Economics 32, 195-222. 
Chatterjee, A. and D.C. Hambrick, 2007, It's all about me: Narcissistic CEOs and their effects on company strategy and performance, Administrative Science Quarterly, 52(3), 351-386.

Chemmanur, T., Paeglis, I., 2005. Management Quality, Certification, and Initial Public Offerings. Journal of Financial Economics 76 (2), 331-368.

Coles, J., N. Daniel, and L. Naveen, 2008, Boards: Does one size fit all? Journal of Financial Economics 87, 329-356.

Coles, J., N. Daniel, and L. Naveen, 2006, Managerial incentives and risk-taking, Journal of Financial Economics, 79, 431-468.

Coles, J., N. Daniel, and L. Naveen, 2011, Co-opted Boards, working paper, Temple UniversityReview of Financial Studies, 27-6, 1751-1796.

Coles, J., M. Lemmon, and J. Meschke, 2011. Structural models and endogeneity in corporate finance: the link between managerial ownership and corporate performance, Journal of Financial Economics, 103-1, 149-168Fortheoming.

Coles, J., M. Lemmon, and Y. Wang, 2008. The joint determinants of managerial ownership, board independence and firm performance, Working paper. Arizona State University.

Coles, J., and Z.C. Li, 2011, Managerial attributes, incentives and performance, Working paper, Arizona State University.

Comment, R., Schwert, G.W., 1995. Poison or placebo? Evidence on the deterrence and wealth effects of modern anti-takeover measures. Journal of Financial Economics 39, 3-43.

Core, J., and W. Guay, 1999. The use of equity grants to manage optimal equity incentive levels. Journal of Accounting and Economics 28, 151-184.

Core, J., and Guay, W., 2002. Estimating the value of employee stock option portfolios and their sensitivities to price and volatility. Journal of Accounting Research 40, 613-630.

Cronqvist, H., A. Low, and M. Nilsson. 2007, Does Corporate Culture Matter for Investment and Financial Policies? Ohio State University Fisher School of Business Working Paper.

Cronqvist, H., A. Makhija, and S, Yonker, 2010. Behavioral Consistency in Corporate Finance: CEO Personal and Corporate Leverage, working paper, Clarement McKenna College Journal of Financial Economics, 103-1, 20-40.

DeAngelo, H., L. DeAngelo, and R. M. Stulz, 2006, Dividend policy and the earned/contributed capital mix: A test of the lifecycle theory, Journal of Financial Economics 81, 227-254.

Denis, D. J., D. Denis, and A. Sarin, 1997, Agency Problems, Equity Ownership, and Corporate Diversification, Journal of Finance, 52-1, 135-160.

Deshmukh, S., Goel, A.M., Howe, K.M., 2010. CEO overconfidence and dividend policy. Working paper, DePaul University and Federal Reserve Bank of Chicag $\Theta \underline{\text { Journal }}$ of Financial Intermediation, 22-3, 440-463.

Erhard, W.H., M. C. Jensen, and S. Zaffron, 2008, Integrity: A positive model that incorporates the normative phenomena of morality, ethics, and legality, Working paper, Harvard Business School.

Finkelstein, S., Hambrick, D., 1996. Strategic Leadership: Top Executives and Their Effects on Organizations. West, New York. 
Frank, M. Z. and V. K. Goyal, 2009. Capital structure decisions: which factors are reliably important? Financial Management, 38(1): 1-37.

Gaver, J., and K. Gaver, 1993. Additional evidence on the association between the investment opportunity set and corporate financing, dividend, and compensation policies. Journal of Accounting and Economics 16, 125-160.

Gillan, S.L. and L.T. Starks. 2000. Corporate Governance Proposals and Shareholder Activism: The Role of Institutional Investors. Journal of Financial Economics 57, 275-305.

Giroud, X., Mueller, H., 2011. Corporate governance, product market competition, and equity prices. Journal of Finance 66, 563-600.

Gompers, P. A., Ishii, J., Metrick, A., 2003. Corporate governance and equity prices. Quarterly Journal of Economics 118 (1), 107-155.

Grable, J. E., 2000. Financial risk tolerance and additional factors that affect risk taking in everyday money matters. Journal of Business and Psychology, 14, 625-630.

Graham, J., and M. Leary, 2011. A Review of Empirical Capital Structure Research and Directions for the Future. Annual Review of Financial Economics, Vol. 3, 2011.

Graham, J., C. Harvey, and M. Puri, 2009, Managerial attitudes and corporate actions, Duke University working paperJournal of Financial Economics, 109-1, 103-121.

Graham, J., S. Li, and J. Qiu, 2011, Managerial attributes and executive compensation, Fortheoming, Review of Financial Studies, 25-1, 144-186.

Guay, W., 1999, The sensitivity of CEO wealth to equity risk: An analysis of the magnitude and determinants, Journal of Financial Economics 53, 43-71.

Guiso, L., Sapienza, P., Zingales, L., 2004. The role of social capital in financial development. American Economic Review 94, 526-556.

Guiso, L., Sapienza, P., Zingales, L., 2008. Trusting the stock market. Journal of Finance 63, 2557-2600.

Hackbarth, D., 2008, Managerial traits and capital structure decisions, Journal of Financial and Quantitative Analysis, 43, 843-882.

Hambrick, D., 1994, Top management groups: A conceptual integration and reconsideration of the team label. In B. M. Staw \& L.L. Cummings (Eds.) Research in Organizational Behavior: 171-214. Greenwich, CT: JAI Press.

Hambrick, D., 2007, Upper echelon theory: An Update, Academy of Management Review, 32 (2), 334-343.

Harford, J., 1999, Corporate Cash Reserves and Acquisitions, Journal of Finance 1969-97.

Harford, J., S. Mansi, and W. Maxwell, 2008, Corporate governance and firm cash holdings in the US, Journal of Financial Economics 87, 535-555.

Harris, M., Raviv, A., 2008. A theory of board control and size. Review of Financial Studies 21, 1797-1832.

Hennessy, C. and T. Whited, 2007, How costly is external financing? Evidence from a structural estimation, Journal of Finance 62, 1705-1745.

Hermalin, B., 2001, Economics and Corporate Culture, in Cary L. Cooper, Sue Cartwright, and P. Christopher Earley, eds.: The International Handbook of Organizational Culture and Climate, John Wiley \& Sons, Chichester, England.

Hermalin, B., and M. Weisbach, 1998, Endogenously chosen boards of directors and their monitoring of the CEO, American Economic Review 88, 96-118. 
Himmelberg, C., Hubbard, R., Palia, D., 1999. Understanding the determinants of managerial ownership and the link between ownership and performance. Journal of Financial Economics 53, 353-384.

Holmstrom, B., 1979. Moral hazard and observability. The Bell Journal of Economics 10, 74-91.

Hutton, I., D. Jiang, A. Kumar, 2010. Do republican managers adopt conservative corporate policies? Working Paper.

Ishii, J. and Y. Xuan, 2010, Acquirer-target social ties and merger outcomes, Working Paper, Stanford University Journal of Financial Economics, 112-3, 344-363.

Jensen, M., 1993, The modern industrial revolution, exit and the failure of internal control systems, Journal of Finance 48, 831-880.

Jensen, M. C., and K. J. Murphy, 1990. Performance pay and top-management incentives. Journal of Political Economy 98, 225-264.

Kaplan, S., M. M. Klebanov and M. Sorensen, 2008, Which CEO characteristics and abilities matter? University of Chicago and NBER working paper Journal of Finance, 67-3, 973-1007.

Kennedy, P., 2003, A Guide to Econometrics, 5th edition, The MIT Press, Cambridge, MA.

Kreps, D., 1990, Corporate Culture and Economic Theory, in James E. Alt, and Kenneth A. Shepsle, eds.: Perspectives on Positive Political Economy, Cambridge University Press, Cambridge, England.

Lazear, E., 1995, Corporate Culture and the Diffusion of Values, in Horst Siebert, ed.: Trends in Business Organization: Do Participation and Cooperation Increase Competitiveness? Institut für Weltwirtschaft an der Universität Kiel, J.C.B. Mohr / Paul Siebeck, Tübingen, Germany.

La Porta, R., Lopez-de-Silanes, F., Shleifer, A. and Vishny, R., 2000, Investor protection and corporate governance", Journal of Financial Economics 58, 3-27.

Lehn, K.M., Patro, S. and Zhao, M., 2009, Determinants of the Size and Composition of US Corporate Boards: 1935-2000. Financial Management, 38: 747-780.

Lemmon, M. L., M. R. Roberts, and J. F. Zender, 2008, Back to the beginning: Persistence and the cross-section of corporate capital structure, Journal of Finance 63, 1575-1608.

Linck, J. S., J. M. Netter, and T. Yang, 2008, The Determinants of Board Structure, Journal of Financial Economics, 87, 308-328.

Li, Z.C., 2011, Pay Gap, Corporate Governance, and Firm Performance. Working Paper. Arizona State University.

Liu, C. and Yermack, D. 2007. Where are the shareholders'_- mansions? CEO home purchases, stock sales, and subsequent performance. Working paper. New York University.

Maksimovic V. and G. Phillips, 2008, The Industry Life Cycle, Acquisitions and Investment: Does Firm Organization Matter? Journal of Finance, 673-709.

Malmendier, U., and S. Nagel, 2011. Depression babies: do macroeconomic experiences affect risk taking? The Quarterly Journal of Economics, 126, 373-416.

Malmendier, U., and G. Tate, 2009. Superstar CEOs. Quarterly Journal of Economics, 124(4): 1593-1638.

Malmendier, U., and G. Tate, 2005, CEO overconfidence and corporate investment, Journal of Finance, 60(6), 2661-2700. 
Malmendier, U., and G. Tate, 2008, Who makes acquisitions? CEO overconfidence and the market's reaction, Journal of Financial Economics, 89(1), 20-43.

Malmendier, U., G. Tate, and J. Yan, 2011, Overconfidence and early-life experiences: The effect of managerial traits on corporate financial policies, Journal of Finance, 66-5, 1687-1733fortheoming.

McConnell, J., Servaes, H., 1990. Additional evidence on equity ownership and corporate value. Journal of Financial Economics 27, 595-612.

Mehran, H., 1995. Executive compensation structure, ownership, and firm performance. Journal of Financial Economics 38, 163-184.

Milbourn, T. 2003. CEO reputation and stock-based compensation. Journal of Financial Economics 68 (2): 233-62.

Mirrlees, J., 1976. The optimal structure of incentives and authority within an organization. Bell Journal of Economics 7, 105-131.

Mitchell, M., and J. Mulherin, 1996. The Impact of Industry Shocks on Takeover and Restructuring Activity. Journal of Financial Economics 41, 193-229.

Mulherin, J., and A. Boone, 2000. Comparing Acquisitions and Divestitures. Journal of Corporate Finance 6, 117-139.

Modigliani, F. and Miller, M., 1958, The Cost of Capital, Corporate Finance and Theory of Investment, American Economic Review, 48, 261-297.

Morck, R., Shleifer, A., Vishny, R., 1988. Management ownership and market valuation: an empirical analysis. Journal of Financial Economics 20, 293-315.

Murphy, K.J., 1999. Executive compensation, Handbook of Labor Economics, in: O. Ashenfelter \& D. Card (ed.), Handbook of Labor Economics, edition 1, volume 3, chapter 38, pages 2485-2563 Elsevier.

Myers, S. and N. Majluf, 1984, Corporate financing and investment decisions when firms have information that investors do not have, Journal of Financial Economics 13, $187-221$.

Parsons, C. and S. Titman, 2008, Empirical capital structure: A review, Foundations and Trends in Finance 3, 1-93.

Raheja, C., 2005. Determinants of board size and composition: a theory of corporate boards. Journal of Financial and Quantitative Analysis 40, 283-306.

Rajgopal, S., T. Shevlin, and V. Zamora. 2006. CEOs' outside employment opportunities and the lack of relative performance evaluation in compensation contracts. The Journal of Finance 61 (4): 1813-44.

Shane, S., 2010, Born Entrepreneurs, Born Leaders How Your Genes Affect Your Work Life, Oxford University Press.

Shivdasani, A. and D. Yermack, 1999, CEO involvement in the selection of new board members: An empirical analysis. Journal of Finance, 54, 1829-1853.

Spencer Stuart, 2009, The Spencer Stuart Board Index.

Weisbach, M., 1988, Outside directors and CEO turnover, Journal of Financial Economics 20, 421-460.

Yermack, D., 1996. Higher market valuation of companies with a small board of directors, Journal of Financial Economics 40, 185-212.

$\mathrm{Yu}, \mathrm{F} ., 2008$, Analyst coverage and earnings management, Journal of Financial Economics 88, 245-71. 


\section{Figure 1}

This figure reports the adjusted $\mathrm{R}^{2}$ of each the regressions based on observed firm and manager characteristics with time fixed effects only versus regressions based on observed firm and manager characteristics and time fixed effects, firm fixed effects, and manager fixed effects.

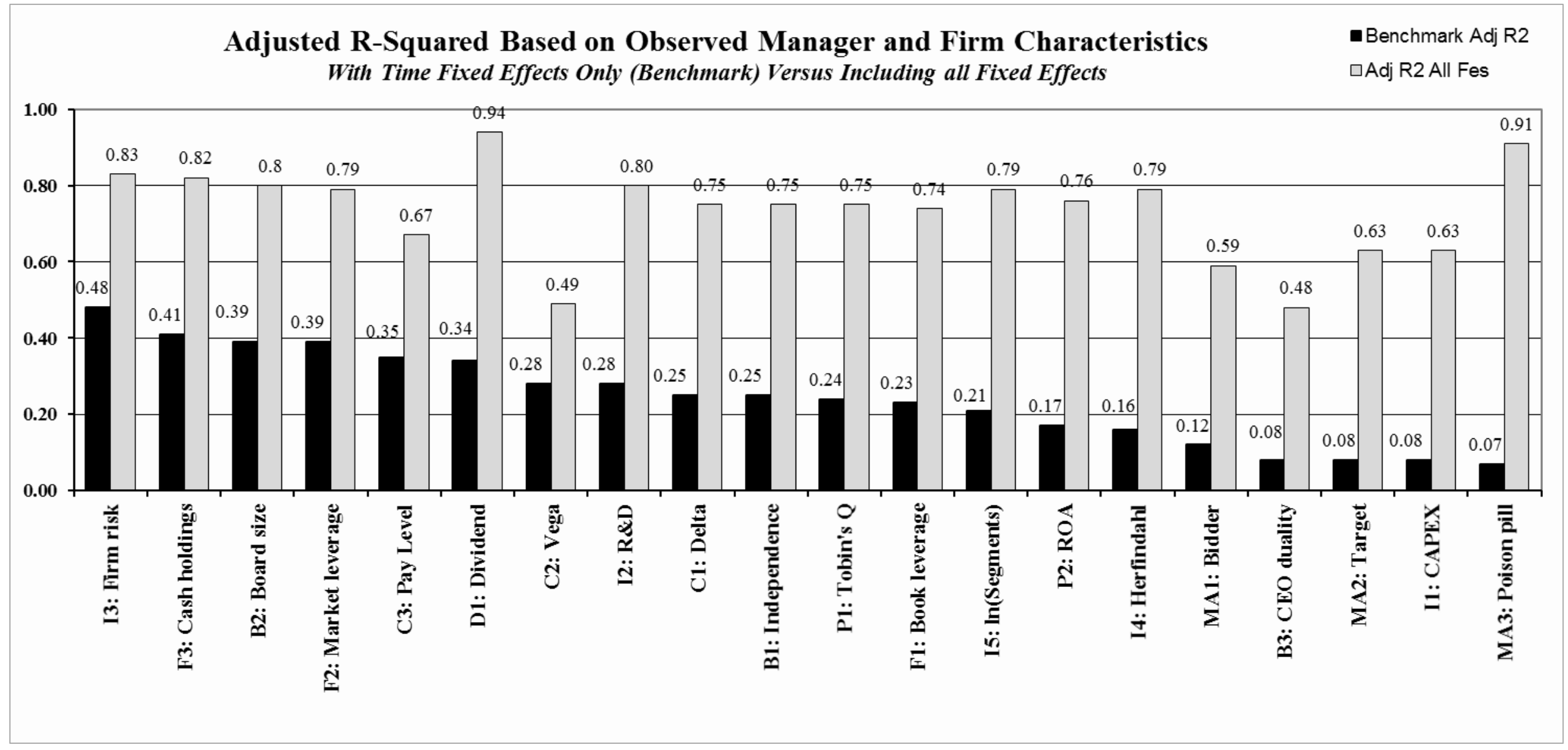




\section{Figure 2}

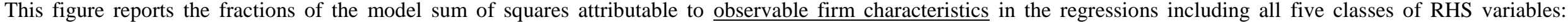
observable firm attributes, observable manager attributes, firm fixed effects, manager fixed effects, and year fixed effects.

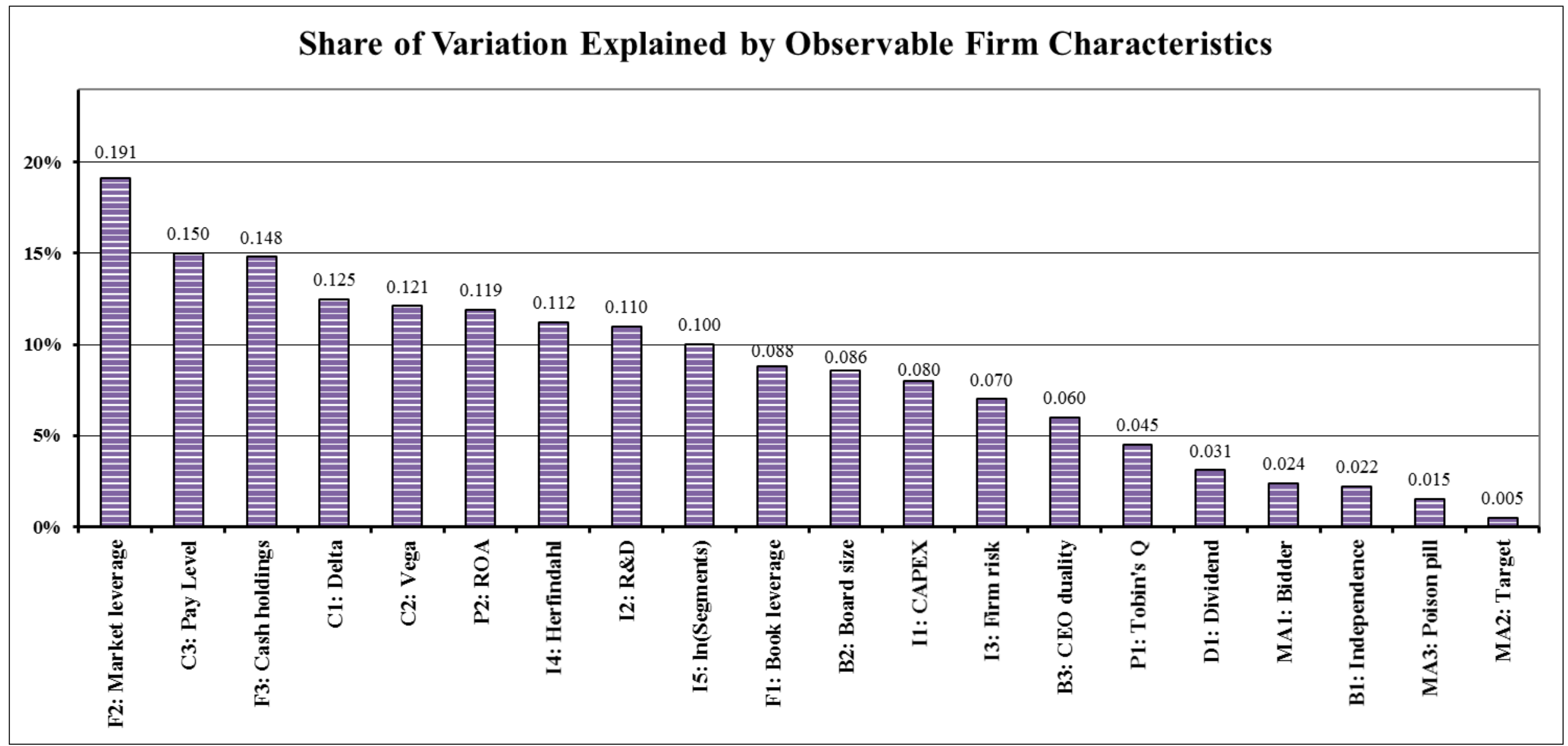




\section{Figure 3}

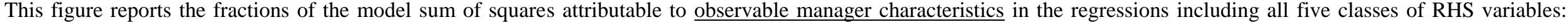
observable firm attributes, observable manager attributes, firm fixed effects, manager fixed effects, and year fixed effects.

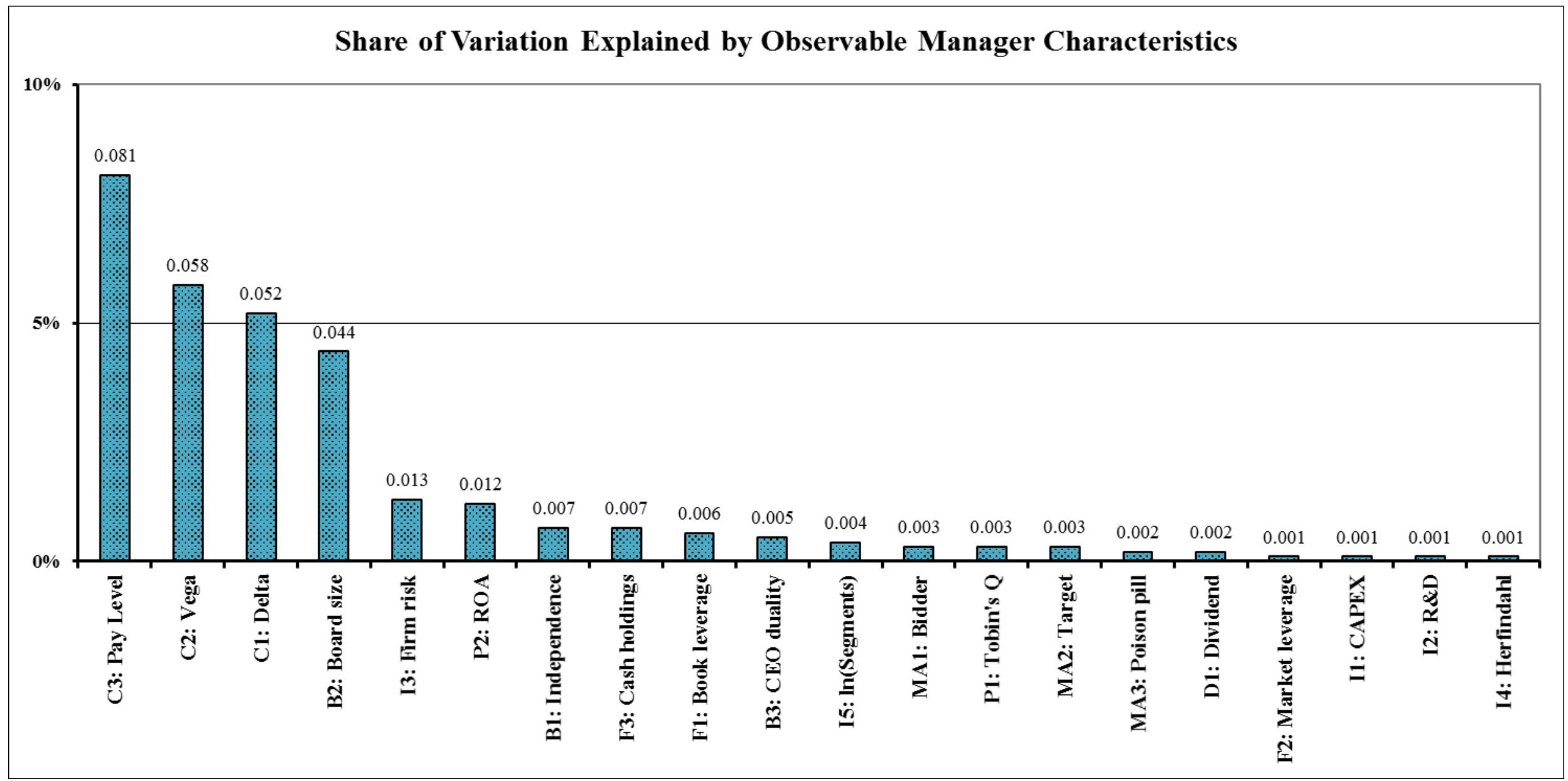




\section{Figure 4}

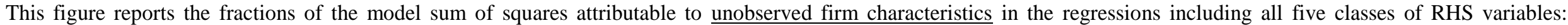
observable firm attributes, observable manager attributes, firm fixed effects, manager fixed effects, and year fixed effects.

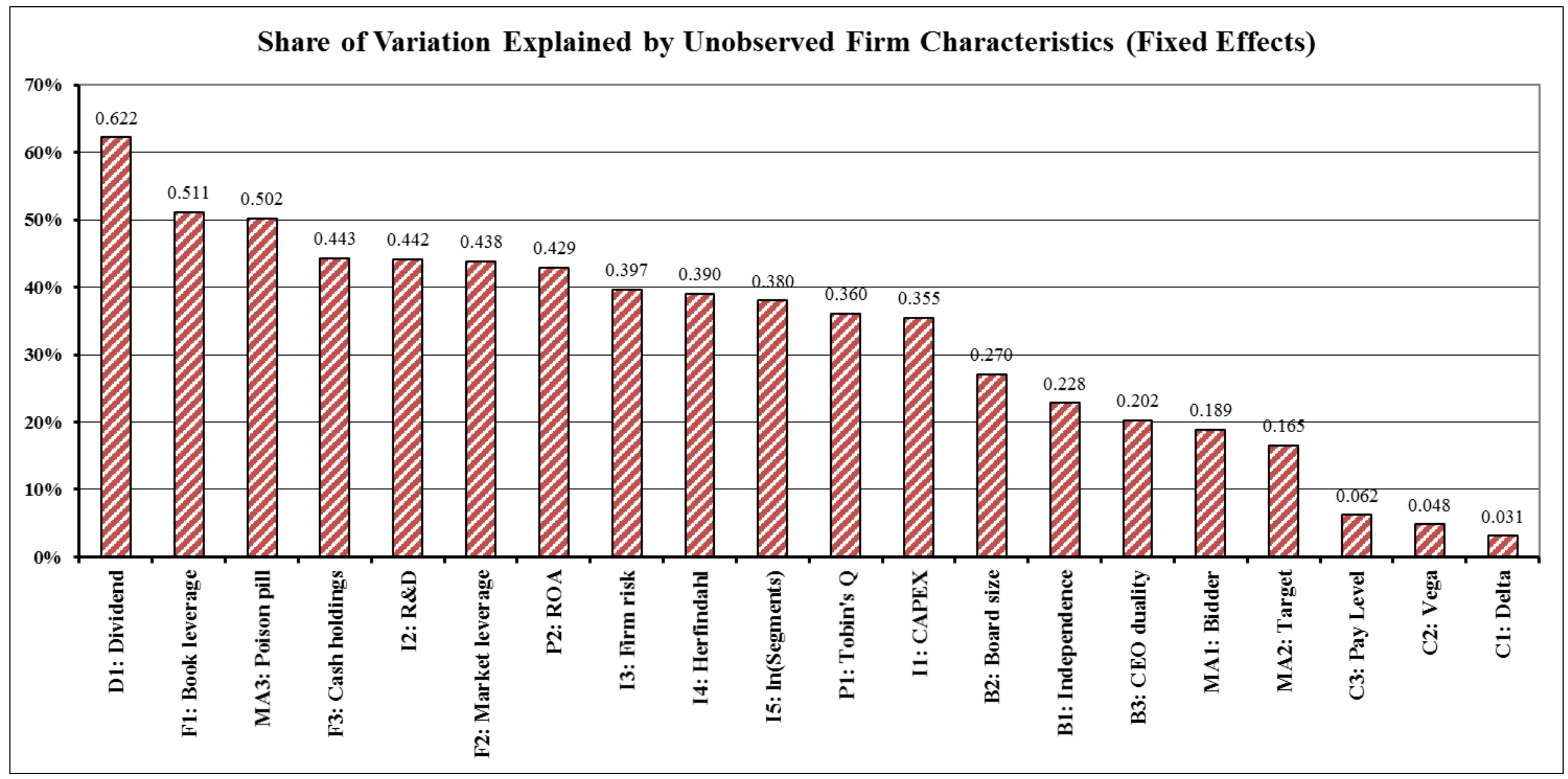




\section{Figure 5}

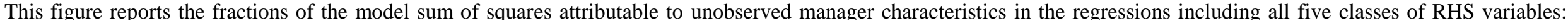
observable firm attributes, observable manager attributes, firm fixed effects, manager fixed effects, and year fixed effects.

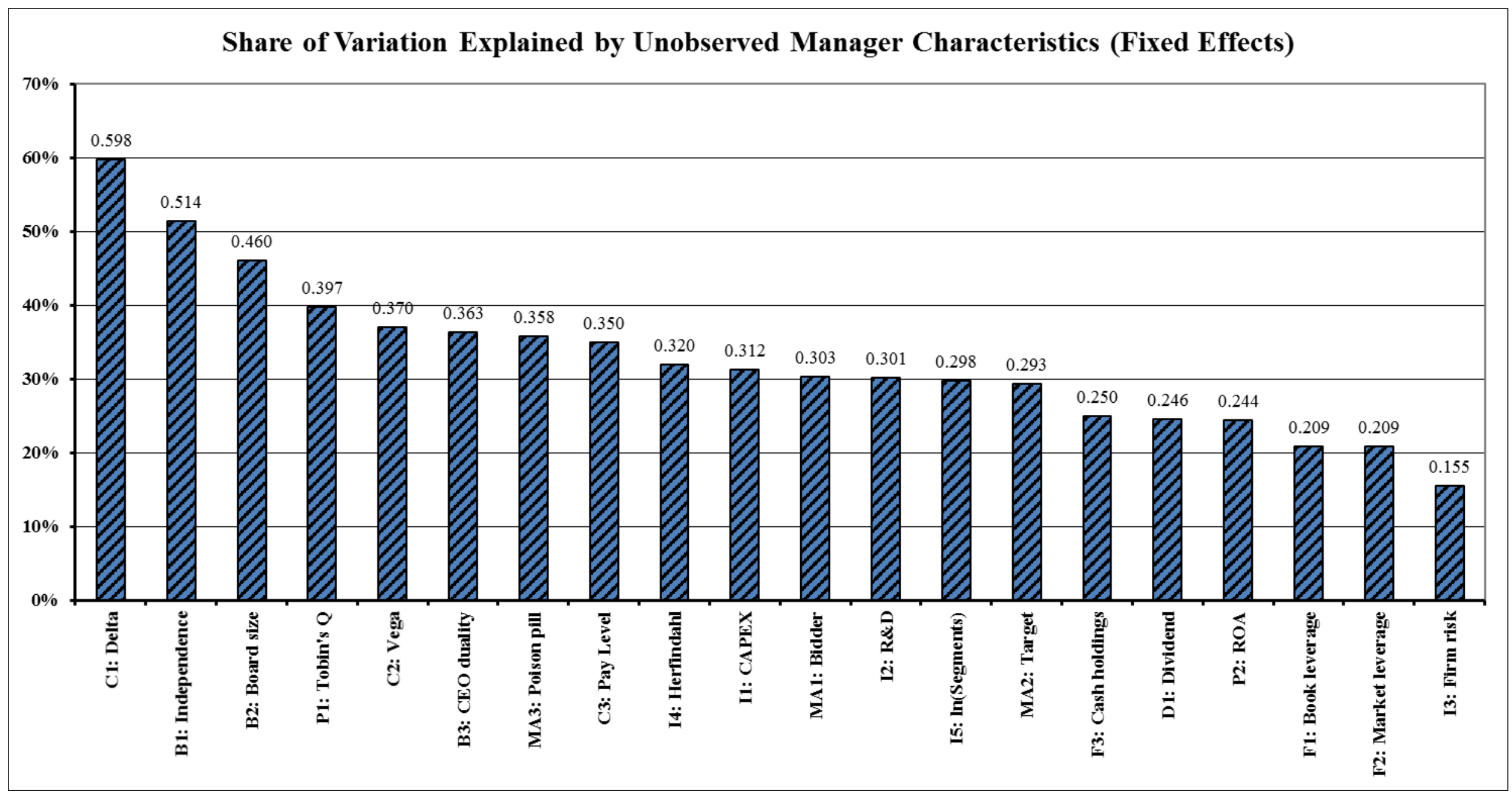




\section{Figure 6}

This figure reports the fractions of the model sum of squares attributable to year fixed effects in the regressions including all five classes of RHS variables: observable firm attributes, observable manager attributes, firm fixed effects, manager fixed effects, and year fixed effects.

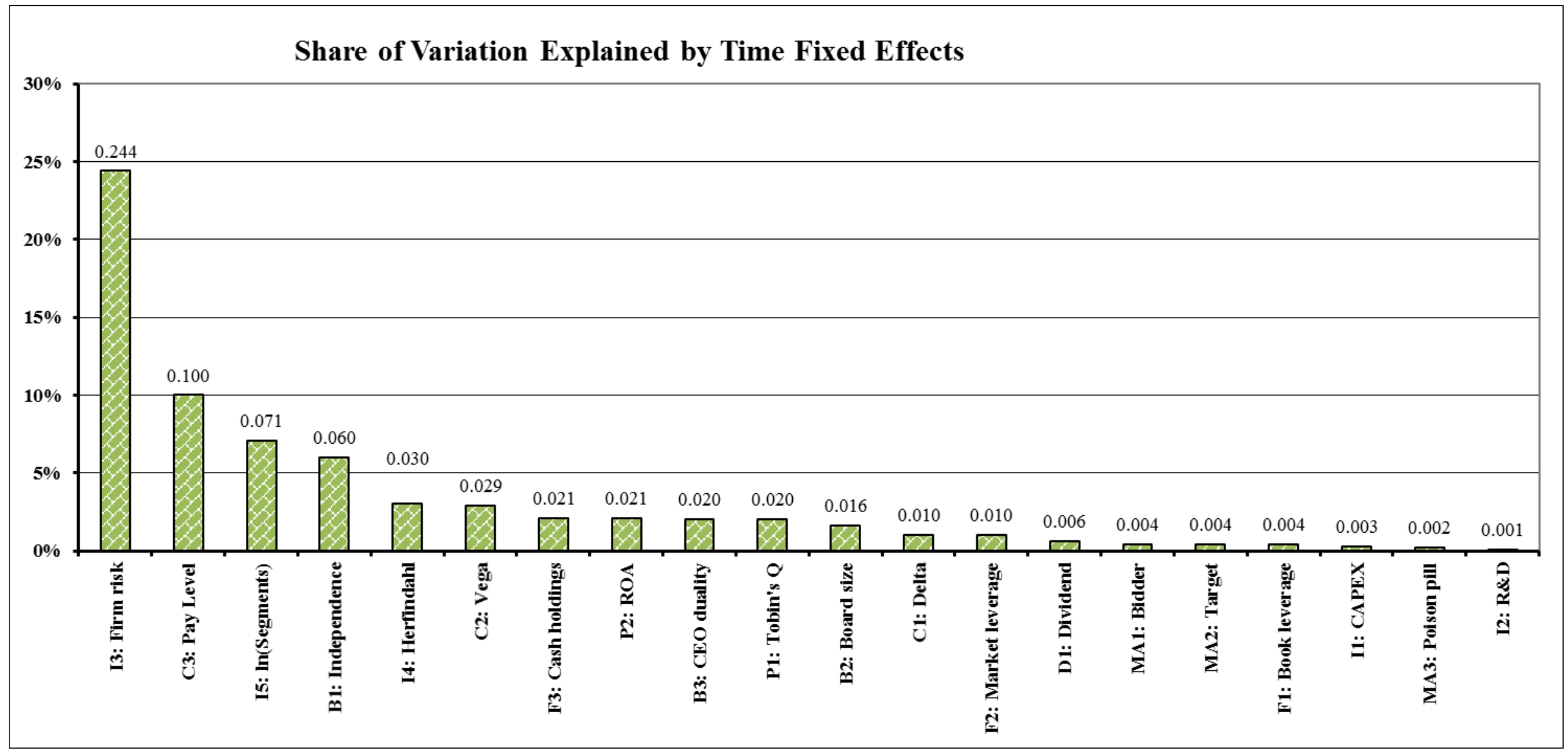




\section{Figure 7}

This figure reports the share in variation of the dependent variable of the five classes of variables and the residual. These components are the fractions of the model sum of squares attributable to particular components. Applying the connected groups method of Abowd, Karmarz, and Margolis (1999) allows separation of firm and manager fixed effects. In addition to the residual, the five remaining classes of variables are observable firm attributes, observable manager attributes, firm fixed effects, manager fixed effects, and year fixed effects.

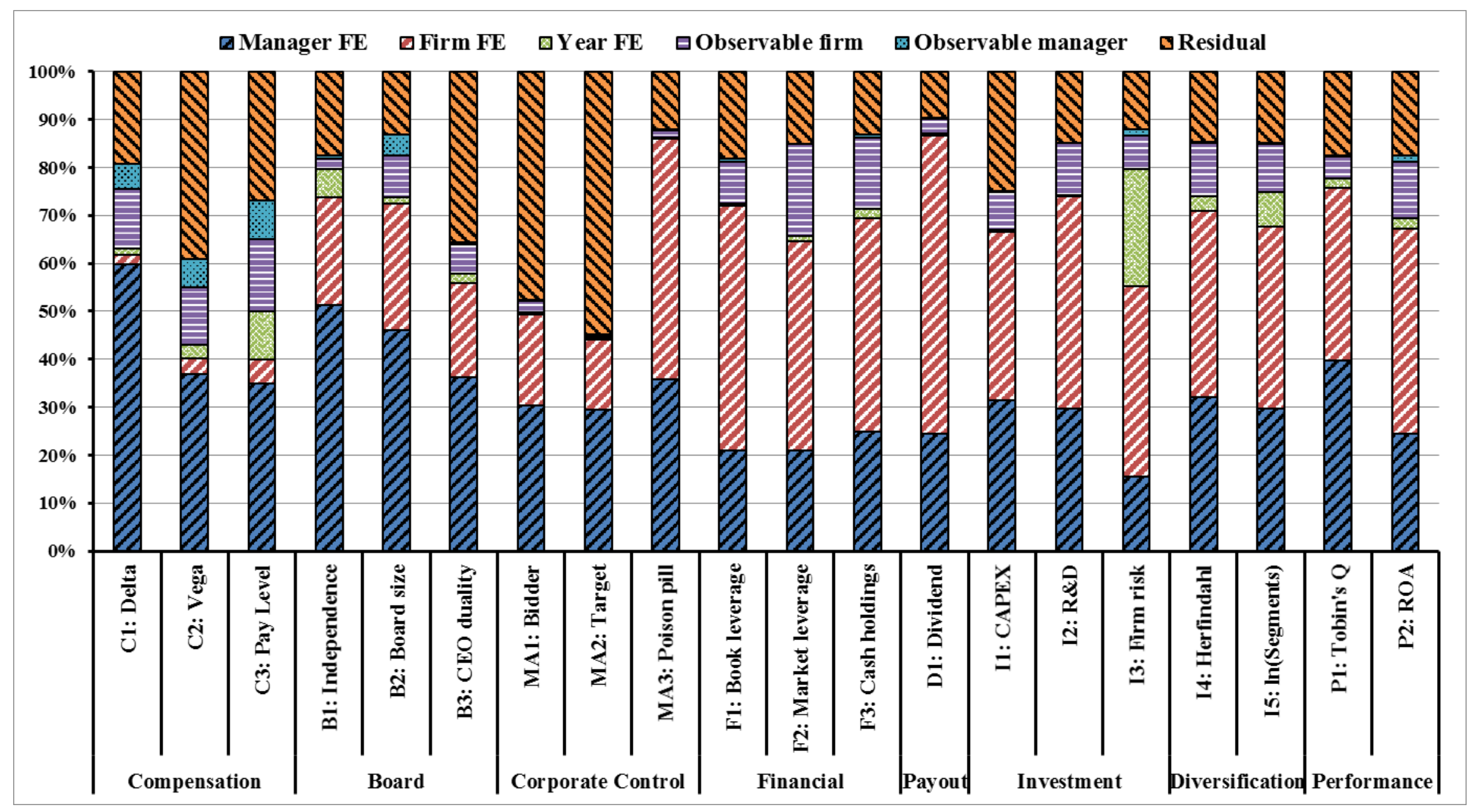




\section{Figure 8}

A taxonomy for placing this paper relative to others, using the example of research on executive compensation.

\begin{tabular}{|c|c|c|c|}
\hline Theory $\rightarrow$ & $\begin{array}{l}\text { Theory and Then } \rightarrow \\
\text { Empirics }\end{array}$ & $\begin{array}{r}\leftarrow \text { Empirics Supported by } \\
\text { Theory }\end{array}$ & $\leftarrow$ Primarily Empirical \\
\hline $\begin{array}{l}\text { Modeling designed to } \\
\text { describe/capture economic } \\
\text { forces and associated } \\
\text { outcomes/predictions }\end{array}$ & $\begin{array}{l}\text { Modeling with direct empirical } \\
\text { application to examine the } \\
\text { efficacy of the model and } \\
\text { whether the model } \\
\text { indentifies/captures relevant } \\
\text { economic features of the } \\
\text { problem }\end{array}$ & $\begin{array}{l}\text { Empirical work supported with } \\
\text { substantial/rigorous modeling } \\
\text { in mathematical or other form. }\end{array}$ & $\begin{array}{l}\text { Empirical experiments with the } \\
\text { empirical design driven by } \\
\text { conventional wisdom or } \\
\text { guidance from prior literature } \\
\text { or casual modeling. }\end{array}$ \\
\hline olmstrom (1979) & $\begin{array}{l}\text { Coles/Lemmon/Wang (2010) } \\
\text { Hennessy/Whited (2007) }\end{array}$ & Coles/ Daniel/Naveen (2006) & $\begin{array}{l}\text { Jensen/Murphy (1990); Guay } \\
\text { (1999) }\end{array}$ \\
\hline$\leftarrow$ & $\leftarrow$ & $\leftarrow$ & $\begin{array}{l}\text { This paper resides here. The } \\
\text { intention is to provide useful } \\
\text { guidance across the other three } \\
\text { categories. }\end{array}$ \\
\hline
\end{tabular}




\section{Table 1}

Summary of results: an empirical examination of empirical corporate finance. NA = not applicable. Composition of total variation in the dependent variable attributable to (six) variable classes is reported as proportions. Composition of explained variation in the dependent variable attributable to (five) variable classes is reported as percentages.

\begin{tabular}{|c|c|c|c|c|c|c|}
\hline \multirow[b]{3}{*}{$\begin{array}{l}\text { Paper (Year/ } \\
\text { T=Table/P=Panel/ } \\
\text { C=Column/ } \\
\text { M=Model })\end{array}$} & \multicolumn{3}{|c|}{ Contract Design } & \multicolumn{3}{|c|}{$\begin{array}{l}\text { Other Corporate Governance } \\
\end{array}$} \\
\hline & Delta & Vega & $\begin{array}{c}\text { Compensation } \\
\text { Level } \\
\end{array}$ & $\begin{array}{c}\text { Board } \\
\text { Independence } \\
\end{array}$ & Board Size & $\begin{array}{c}\begin{array}{c}\text { Leadership Structure } \\
\text { (Duality) }\end{array} \\
\end{array}$ \\
\hline & $\begin{array}{l}\text { Coles/Daniel/ } \\
\text { Naveen (2006/ } \\
\text { T 3/P A/C 3) }\end{array}$ & $\begin{array}{l}\text { Coles/Daniel/ } \\
\text { Naveen (2006/ } \\
\text { T 3/P A/C 2) }\end{array}$ & $\begin{array}{c}\text { Graham/Li/Qiu } \\
(2011 / \mathrm{T} \mathrm{4/P} \mathrm{A/C} \\
1)\end{array}$ & $\begin{array}{l}\text { Linck/Netter/Yang } \\
\text { (2008/T 4/C 2) }\end{array}$ & $\begin{array}{l}\text { Linck/Netter/Yang } \\
\text { (2008/T 4/M 1) }\end{array}$ & $\begin{array}{c}\text { Linck/Netter/Yang } \\
\text { (2008/T 4/M 3) }\end{array}$ \\
\hline $\mathbf{N} ; \mathbf{A d j} . \mathbf{R}^{2}$ & 5,$352 ; 0.48$ & 5,$352 ; 0.20$ & 65,$421 ; 0.49$ & 8,$840 ; 0.17$ & 10,$636 ; 0.44$ & 3,$610 ; 0.116$ \\
\hline Data Years & $1992-2002$ & $1992-2002$ & $1992-2006$ & $1990-2004$ & $1990-2004$ & $1990-2004$ \\
\hline Dependent Variable & CEO $\ln ($ delta $)$ & CEO vega & $\begin{array}{l}\log (\text { executive total } \\
\text { pay) }\end{array}$ & Board independence & Board size & Board leadership \\
\hline Notes & Industry year $\mathrm{FE}$ & & & Industry, year FE & Industry, year FE & Industry, year FE \\
\hline \multicolumn{7}{|c|}{ Our Sample Based on AKM Connected Group Method (Data years 1993-2013) } \\
\hline Sample Size & 83,670 & 83,670 & 83,670 & 36,745 & 36,745 & 30,891 \\
\hline Dep. Variable & NEO delta & NEO vega & NEO total pay & Board Independence & Board Size & Board leadership \\
\hline Adj.R ${ }^{2}$ : No FEs & 0.25 & 0.28 & 0.35 & 0.25 & 0.39 & 0.08 \\
\hline $\begin{array}{l}\text { Adj. } R^{2}: \text { Mgr and } \\
\text { Firm FEs }\end{array}$ & 0.75 & 0.49 & 0.67 & 0.75 & 0.80 & 0.48 \\
\hline \multicolumn{7}{|c|}{ Proportion of Total Variation Explained (Rank)/Proportion of Explained Variation Explained: } \\
\hline Manager Attributes & $0.052(3) / 6.37 \%$ & $0.058(2) / 9.27 \%$ & $0.081(1) / 10.90 \%$ & $0.007(7) / 0.84 \%$ & $0.044(4) / 5.02 \%$ & $0.005(10) / 0.78 \%$ \\
\hline Firm Attributes & $0.124(4) / 15.32 \%$ & $0.121(4) / 19.32 \%$ & $0.150(2) / 20.19 \%$ & $0.022(18) / 2.63 \%$ & $0.086(11) / 9.81 \%$ & $0.060(14) / 9.23 \%$ \\
\hline Year FEs & $0.010(12) / 1.23 \%$ & $0.029(6) / 4.62 \%$ & $0.100(2) / 13.46 \%$ & $0.060(4) / 7.22 \%$ & $0.016(11) / 1.82 \%$ & $0.020(9) / 3.08 \%$ \\
\hline Manager FEs & $0.598(1) / 73.28 \%$ & $0.370(5) / 59.10 \%$ & $0.350(8) / 47.10 \%$ & $0.514(2) / 59.70 \%$ & $0.460(3) / 52.50 \%$ & $0.363(6) / 55.85 \%$ \\
\hline Firm FEs & $0.031(20) / 3.80 \%$ & $0.048(19) / 7.67 \%$ & $0.062(18) / 8.34 \%$ & $0.228(14) / 27.44 \%$ & $0.270(13) / 30.82 \%$ & $0.202(15) / 31.08 \%$ \\
\hline Residual & $0.186(7) / \mathrm{NA}$ & $0.374(3) / \mathrm{NA}$ & $0.257(5) / \mathrm{NA}$ & $0.169(10) / \mathrm{NA}$ & $0.124(16) / \mathrm{NA}$ & $0.350(4) / \mathrm{NA}$ \\
\hline $\begin{array}{l}\text { Changes in } \\
\text { Inference? }\end{array}$ & $\begin{array}{l}\text { Firm risk, board } \\
\text { independence }\end{array}$ & $\begin{array}{l}\text { Age, } \mathrm{R} \& \mathrm{D}, \text { firm } \\
\text { risk, market-to- } \\
\text { book }\end{array}$ & Age, R\&D & Debt, firm age & & \\
\hline
\end{tabular}




\begin{tabular}{|c|c|c|c|c|c|c|}
\hline \multirow{3}{*}{$\begin{array}{l}\text { Paper }(\text { Year/ } \\
\text { T=Table/P=Panel/ } \\
\text { C=Column/ } \\
\text { M=Model })\end{array}$} & \multicolumn{3}{|c|}{ Corporate Control } & \multicolumn{3}{|c|}{ Financial Policy } \\
\hline & M\&A Bidder & M\&A Target & $\begin{array}{c}\text { Takeover } \\
\text { Protections (Pill) }\end{array}$ & Book Leverage & Market Leverage & Cash Holdings \\
\hline & $\begin{array}{l}\text { Harford (1999/T } \\
\text { III/C 3) }\end{array}$ & $\begin{array}{l}\text { Comment/Schwert } \\
(1995 / \mathrm{T} 3 / \mathrm{C} 1)\end{array}$ & $\begin{array}{l}\text { Comment/Schwert } \\
(1995 / \mathrm{T} 3 / \mathrm{C} 3)\end{array}$ & $\begin{array}{c}\text { Lemmon/Roberts/ } \\
\text { Zender (2008/ } \\
\text { T II/P A/C 3) }\end{array}$ & $\begin{array}{c}\text { Lemmon/Roberts/ } \\
\text { Zender (2008/ } \\
\text { T II/P A/C 6) }\end{array}$ & $\begin{array}{l}\text { Harford/Mansi/ } \\
\text { Maxwell (2008/ } \\
\text { T 3/C 1) }\end{array}$ \\
\hline $\mathbf{N}$; Adj. $\mathbf{R}^{2}$ & 2,857 & 21,869 & 21,871 & 117,$914 ; 0.30$ & 117,300 & 11,$645 ; 0.47$ \\
\hline Data Years & $1991-93$ & $1977-1991$ & $1977-1991$ & $1965-2003$ & $1965-2003$ & $1993-2004$ \\
\hline Dependent Variable & Bidder & Target & Poison pill & Book Leverage & Market Leverage & Cash holdings \\
\hline Notes & & Year FE & Year FE & Year FE & Year FE & \\
\hline \multicolumn{7}{|c|}{ Our Sample Based on AKM Connected Group Method (Data years 1993-2013) } \\
\hline Sample Size & 64,428 & 48,365 & 48,365 & 73,629 & 73,629 & 63,698 \\
\hline Dep. Variable & Bidder & Target & Poison pill & Book Leverage & Market Leverage & Cash holdings \\
\hline $\begin{array}{l}\text { Adj.R }{ }^{2}: \text { No Fixed } \\
\text { Effects }\end{array}$ & 0.12 & 0.08 & 0.07 & 0.23 & 0.39 & 0.41 \\
\hline $\begin{array}{l}\text { Adj. } \mathbf{R}^{2} \text { : Mgr and Firm } \\
\text { FEs }\end{array}$ & 0.58 & 0.63 & 0.91 & 0.74 & 0.79 & 0.82 \\
\hline \multicolumn{7}{|c|}{ Proportion of Total Variation Explained (Rank)/Proportion of Explained Variation Explained: } \\
\hline Manager Attributes & $0.003(12) / 0.57 \%$ & $0.003(14) / 0.64 \%$ & $0.002(14) / 0.23 \%$ & $0.006(9) / 0.73 \%$ & $0.001(17) / 0.13 \%$ & $0.007(8) / 0.80 \%$ \\
\hline Firm Attributes & $0.024(17) / 4.59 \%$ & $0.005(20) / 0.75 \%$ & $0.015(19) / 1.70 \%$ & $0.088(10) / 10.76 \%$ & $0.191(1) / 22.50 \%$ & $0.148(3) / 17.03 \%$ \\
\hline Year Fixed Effects & $0.004(15) / 0.76 \%$ & $0.004(15) / 0.60 \%$ & $0.002(19) / 0.23 \%$ & $0.004(17) / 0.49 \%$ & $0.010(12) / 1.17 \%$ & $0.021(7) / 2.42 \%$ \\
\hline Manager Fixed Effects & $0.303(11) / 57.93 \%$ & $0.293(14) / 62.34 \%$ & $0.356(8) / 40.60 \%$ & $0.209(18) / 25.55 \%$ & $0.209(19) / 24.62 \%$ & $0.250(15) / 28.77 \%$ \\
\hline Firm Fixed Effects & $0.189(16) / 36.14 \%$ & $0.165(17) / 32.67 \%$ & $0.50(3) / 57.24 \%$ & $0.511(2) / 62.47 \%$ & $0.438(6) / 51.57 \%$ & $0.443(4) / 50.97 \%$ \\
\hline Residual & $0.477(2) / \mathrm{NA}$ & $0.530(1) / \mathrm{NA}$ & $0.123(18) / \mathrm{NA}$ & $0.182(7) / \mathrm{NA}$ & $0.151(12) / \mathrm{NA}$ & $0.131(17) / \mathrm{NA}$ \\
\hline Changes in Inference? & & Poison pill & $\begin{array}{l}\text { Control share law, } \\
\text { PE, size, CEO }\end{array}$ & $\log ($ sales $)$ & Director & $\begin{array}{l}\text { R\&D, bond } \\
\text { indicator }\end{array}$ \\
\hline
\end{tabular}




\begin{tabular}{|c|c|c|c|c|}
\hline & Payout Policy & \multicolumn{3}{|c|}{ Investment Policy } \\
\hline \multirow{2}{*}{$\begin{array}{l}\text { Paper }(\text { Year/ } \\
\text { T=Table/P=Panel/ } \\
\text { C=Column/ } \\
\text { M=Model })\end{array}$} & Dividend Payout & Capital Expenditure & R\&D & $\begin{array}{c}\text { Firm risk } \\
\end{array}$ \\
\hline & $\begin{array}{c}\text { DeAngelo/ } \\
\text { DeAngelo/Stulz (2006/T 3/ } \\
\text { Row D6) }\end{array}$ & $\begin{array}{c}\text { Coles/Daniel/ } \\
\text { Naveen (2006/ } \\
\text { T 3/P B/C 1) }\end{array}$ & $\begin{array}{l}\text { Coles/Daniel/ } \\
\text { Naveen (2006/ } \\
\text { T 3/P A/C 1) }\end{array}$ & $\begin{array}{c}\text { Coles/Daniel/Naveen (2006/ } \\
\text { T 9/C 1) }\end{array}$ \\
\hline $\mathbf{N} ;$ Adj. $\mathbf{R}^{2}$ & & 9,$422 ; 0.29$ & 9,$551 ; 0.39$ & 9,$689 ; 0.39$ \\
\hline Data Years & $1973-2002$ & $1992-2002$ & $1992-2002$ & $1992-2002$ \\
\hline Dependent Variable & Dividend Payout & CAPEX & R\&D & Firm risk \\
\hline Notes & Industrial firms & Industry FE & Industry FE & Industry FE \\
\hline \multicolumn{5}{|c|}{ Our Sample Based on AKM Connected Group Method (Data years 1993-2013) } \\
\hline Sample Size & 31,980 & 46,103 & 68,924 & 67,846 \\
\hline Dep. Variable & Dividend Payout & CAPEX & R\&D & Firm risk \\
\hline Adj.R²: No FEs & 0.34 & 0.08 & 0.28 & 0.48 \\
\hline $\begin{array}{l}\text { Adj. } R^{2}: \text { Mgr and Firm } \\
\text { FEs }\end{array}$ & 0.94 & 0.63 & 0.80 & 0.83 \\
\hline \multicolumn{5}{|c|}{ Proportion of Total Variation Explained (Rank)/Proportion of Explained Variation Explained: } \\
\hline Manager Attributes & $0.002(16) / 0.22 \%$ & $0.001(18) / 0.13 \%$ & $0.001(19) / 0.12 \%$ & $0.013(5) / 1.85 \%$ \\
\hline Firm Attributes & $0.031(16) / 3.41 \%$ & $0.080(12) / 10.67 \%$ & $0.110(8) / 12.87 \%$ & $0.070(13) / 7.96 \%$ \\
\hline Year FEs & $0.006(14) / 0.67 \%$ & $0.003(18) / 0.40 \%$ & $0.001(20) / 0.12 \%$ & $0.244(1) / 27.67 \%$ \\
\hline Manager FEs & $0.246(16) / 27.12 \%$ & $0.312(10) / 41.60 \%$ & $0.301(12) / 35.20 \%$ & $0.155(20) / 17.63 \%$ \\
\hline Firm FEs & $0.622(1) / 68.58 \%$ & $0.355(12) / 47.33 \%$ & $0.442(5) / 51.70 \%$ & $0.397(8) / 45.16 \%$ \\
\hline Residual & $0.093(20) / \mathrm{NA}$ & $0.250(6) / \mathrm{NA}$ & $0.145(13) / \mathrm{NA}$ & $0.121(19) / \mathrm{NA}$ \\
\hline Changes in Inference? & TE/TA, MTB & Vega, Surplus cash & Book Leverage & Book Leverage, director \\
\hline
\end{tabular}




\begin{tabular}{|c|c|c|c|c|}
\hline & \multicolumn{2}{|c|}{ Diversification } & \multicolumn{2}{|c|}{ Firm Performance } \\
\hline \multirow[b]{2}{*}{$\begin{array}{l}\text { Paper }(\text { Year/ } \\
\text { T=Table/P=Panel/ } \\
\text { C=Column/ } \\
\text { M=Model })\end{array}$} & Herfindahl Index & $\ln ($ segments $)$ & Valuation Ratio (Tobin's Q) & Accounting (ROA) \\
\hline & $\begin{array}{c}\text { Coles/Daniel/Naveen (2006/ } \\
\text { T 4/P A/C 1) }\end{array}$ & $\begin{array}{c}\text { Coles/Daniel/Naveen (2006/ } \\
\text { T 4/P B/C 1) }\end{array}$ & $\begin{array}{c}\text { Mehran (1995/ } \\
\text { T 4/P A/C 4) }\end{array}$ & $\begin{array}{c}\text { Mehran (1995/ } \\
\text { T 4/P B/C 4) }\end{array}$ \\
\hline $\mathbf{N} ;$ Adj. $\mathbf{R}^{2}$ & 4,$219 ; 0.29$ & 4,$220 ; 0.32$ & $153 ; 0.43$ & $153 ; 0.30$ \\
\hline Data Years & $1992-2002$ & $1992-2002$ & 1979-1980 & 1979-1980 \\
\hline Dependent Variable & Herfindahl Index & $\ln ($ segments) & Tobin's Q & ROA \\
\hline Notes & Industry FE & Industry FE & manufacturing firms & manufacturing firms \\
\hline \multicolumn{5}{|c|}{ Our Sample Based on AKM Connected Group Method (Data years 1993-2013) } \\
\hline Sample Size & 61,825 & 61,825 & 31,918 & 31,918 \\
\hline Dep. Variable & Herfindahl Index & $\ln ($ segments) & Tobin's Q & ROA \\
\hline Adj.R2: No FEs & 0.16 & 0.21 & 0.23 & 0.17 \\
\hline $\begin{array}{l}\text { Adj. } \text { R }^{2} \text { : Mgr and Firm } \\
\text { FEs }\end{array}$ & 0.79 & 0.79 & 0.74 & 0.76 \\
\hline \multicolumn{5}{|c|}{ Proportion of Total Variation Explained (Rank)/Proportion of Explained Variation Explained: } \\
\hline Manager Attributes & $0.001(17) / 0.12 \%$ & $0.004(11) / 0.49 \%$ & $0.003(12) / 0.36 \%$ & $0.012(6) / 1.45 \%$ \\
\hline Firm Attributes & $0.112(7) / 13.13 \%$ & $0.100(9) / 11.72 \%$ & $0.045(14) / 5.45 \%$ & $0.119(6) / 14.42 \%$ \\
\hline Year FEs & $0.030(6) / 3.52 \%$ & $0.071(3) / 8.32 \%$ & $0.020(8) / 2.42 \%$ & $0.021(8) / 2.54 \%$ \\
\hline Manager FEs & $0.320(9) / 37.51 \%$ & $0.298(13) / 34.94 \%$ & $0.397(4) / 48.12 \%$ & $0.244(16) / 29.57 \%$ \\
\hline Firm FEs & $0.390(9) / 45.72 \%$ & $0.380(10) / 44.55 \%$ & $0.360(11) / 43.63 \%$ & $0.429(6) / 52.00 \%$ \\
\hline Residual & $0.147(14) / \mathrm{NA}$ & $0.147(15) / \mathrm{NA}$ & $0.175(9) / \mathrm{NA}$ & $0.175(11) / \mathrm{NA}$ \\
\hline Changes in Inference? & $\begin{array}{l}\text { Vega, Cash compensation, } \\
\text { Sales growth, Age }\end{array}$ & $\begin{array}{l}\text { Cash compensation, Sales } \\
\text { growth, Age }\end{array}$ & $\begin{array}{c}\text { Delta, \% ind directors. Stdev } \\
\text { operating income, log assets, } \\
\text { Tenure }\end{array}$ & CEO \\
\hline
\end{tabular}


Table 2

Summary Statistics

This table presents summary statistics for the full sample of the cross-sectional yearly data from 1993 to 2013. Refer to the Appendix (Variable Definitions). All dollar values are stated in 2013 dollars. Delta is in \$millions for a $1 \%$ change in equity value, vega is in \$millions per 0.01 change in standard deviation of stock return, and total compensation and net assets are in \$millions. Vega, delta, total compensation, and market-to-book are winsorized at the 1st and 99th percentile levels. The number of executive-year observations with no missing data values is 104,260 for the spell sample, 9,816 for the MDV sample, and 64,245 for the AKM sample.

\begin{tabular}{|c|c|c|c|}
\hline & Mean & Median & Stdev \\
\hline Managerial Attributes & & & \\
\hline Age & 52 & 51 & 7.85 \\
\hline Tenure & 10 & 5 & 10.66 \\
\hline Female & 0.06 & 0 & 0.24 \\
\hline CEO & 0.16 & 0 & 0.36 \\
\hline Director & 0.28 & 0 & 0.45 \\
\hline Mover & 0.15 & 0 & 0.37 \\
\hline $\begin{array}{l}\text { Coles, Daniel, and Naveen (2006) Variables } \\
\text { Delta (\$ mil) }\end{array}$ & 0.23 & 0.04 & 0.60 \\
\hline Vega $(\$$ mil $)$ & 0.05 & 0.01 & 0.09 \\
\hline Market-to-book & 1.98 & 1.35 & 2.52 \\
\hline Firm risk & 2.81 & 2.70 & 0.94 \\
\hline Log (Net Assets) & 5.94 & 6.22 & 2.88 \\
\hline $\mathrm{R} \& \mathrm{D}$ & 0.03 & 0 & 0.10 \\
\hline Surplus Cash & 0.10 & 0.08 & 0.15 \\
\hline Board Independence & 70.13 & 72.73 & 16.67 \\
\hline Institutional Holdings & 56.84 & 60.10 & 22.80 \\
\hline ROA & 0.13 & 0.10 & 0.14 \\
\hline PPE & 0.27 & 0.18 & 0.26 \\
\hline CAPEX & 0.05 & 0.03 & 0.07 \\
\hline Leverage & 0.17 & 0.12 & 0.17 \\
\hline Sales growth & 0.09 & 0.06 & 0.30 \\
\hline Cash compensation & 0.75 & 0.50 & 1.10 \\
\hline Stock Return & 0.01 & 0.001 & 0.55 \\
\hline Herfindahl Index & 0.80 & 1.00 & 0.27 \\
\hline Dividend Cut & 0.26 & 0 & 0.40 \\
\hline CEO Turnover & 0.16 & 0 & 0.36 \\
\hline $\operatorname{Ln}($ Segments $)$ & 0.48 & 0 & 0.03 \\
\hline $\begin{array}{l}\text { Linck, Netter, and Yang (2008) Variables } \\
\text { Board size }\end{array}$ & 9.60 & 9 & 2.79 \\
\hline Board leadership & 0.80 & 1 & 0.40 \\
\hline LogMVE & 7.10 & 6.95 & 1.61 \\
\hline Debt & 0.20 & 0.18 & 0.15 \\
\hline FirmAge & 11.22 & 7.00 & 12.10 \\
\hline RETSTD & 0.41 & 0.36 & 0.21 \\
\hline CEO_Own & 0.53 & 0.07 & 0.27 \\
\hline
\end{tabular}




\begin{tabular}{|c|c|c|c|}
\hline Director_Own & 0.96 & 0.90 & 0.83 \\
\hline FCF & 0.08 & 0.06 & 0.10 \\
\hline Performance & 0.004 & 0.004 & 0.02 \\
\hline Lag(CEO_Chair) & 0.77 & 1 & 0.38 \\
\hline \multicolumn{4}{|l|}{ Harford (1999) Variables } \\
\hline Bidder & 0.14 & 0 & 0.32 \\
\hline Abnormal return & 0.01 & 0.001 & 0.45 \\
\hline Noncash working capital & 0.01 & 0.002 & 0.10 \\
\hline Price-to-earnings & 15.93 & 14.61 & 14.02 \\
\hline Size & 7.40 & 7.33 & 1.61 \\
\hline \multicolumn{4}{|c|}{ Comment and Schwert (1995) Variables } \\
\hline Liquidity & 0.10 & 0.03 & 0.10 \\
\hline Debt/equity & 0.20 & 0.20 & 0.17 \\
\hline Control share law & 0.18 & 0 & 0.33 \\
\hline Business combination law & 0.70 & 1 & 0.45 \\
\hline Poison pill & 0.63 & 1 & 0.45 \\
\hline \multicolumn{4}{|c|}{ Lemmon, Roberts, and Zender (2008) Variables } \\
\hline Initial book leverage & 0.20 & 0.19 & 0.19 \\
\hline Initial market leverage & 0.20 & 0.16 & 0.20 \\
\hline Profitability & 0.12 & 0.13 & 0.13 \\
\hline Cash Flow Volatility & 0.05 & 0.03 & 0.05 \\
\hline Tangibility & 0.28 & 0.25 & 0.20 \\
\hline Dividend Payer & 0.55 & 1 & 0.44 \\
\hline \multicolumn{4}{|c|}{ Harford, Mansi, and Maxwell (2008) Variables } \\
\hline Cash Holdings & -2.68 & -2.54 & 1.62 \\
\hline Gindex & 9.20 & 9.00 & 2.70 \\
\hline Inside Ownership & 0.002 & 0.001 & 0.004 \\
\hline Size & 7.35 & 7.22 & 1.48 \\
\hline Working capital & 0.08 & 0.06 & 0.18 \\
\hline CF Volatility & 0.05 & 0.03 & 0.05 \\
\hline $\mathrm{R} \& \mathrm{D}$ & 0.03 & 0 & 0.10 \\
\hline CapEx & 0.05 & 0.03 & 0.07 \\
\hline Acquisition & 0.03 & 0 & 0.06 \\
\hline Dividend indicator & 0.55 & 1 & 0.44 \\
\hline Bond indicator & 0.59 & 1 & 0.49 \\
\hline \multicolumn{4}{|c|}{ DeAngelo, DeAngelo, and Stulz (2006) Variables } \\
\hline Dividend payout & 0.55 & 1 & 0.46 \\
\hline $\mathrm{RE} / \mathrm{TE}$ & 0.42 & 0.03 & 0.23 \\
\hline TE/TA & 0.56 & 0.40 & 0.61 \\
\hline Sales growth & 0.09 & 0.06 & 0.30 \\
\hline \multicolumn{4}{|l|}{ Mehran (1995) Variables } \\
\hline Tobin's Q & 2.16 & 1.67 & 2.70 \\
\hline
\end{tabular}


$\%$ of managers' equity compensation

$\%$ of shares held by all outside blockholders

$\%$ of outside directors

Std of $\%$ change in operating income $\begin{array}{lll}0.56 & 0.60 \quad 0.23\end{array}$

$\begin{array}{lll}0.17 & 0 & 0.30\end{array}$

$\begin{array}{lll}0.70 & 0.72 \quad 0.17\end{array}$

$\begin{array}{lll}0.43 & 0.33 \quad 0.34\end{array}$ 
Table 3

Observable and Unobservable Determinants of Delta - Connectedness Sample with AKM Method

This table presents the results for specifications regressing managerial delta on observable managerial and firm characteristics and on various combinations of fixed effects that proxy for time and for unobserved manager and firm attributes. The benchmark specification (model (1) in Panel A) is a pooled OLS regression, without firm or manager fixed effects (FE), which is based on the explanatory variables in Table 3, Panel A, Column 3 in Coles, Daniel, and Naveen (2006) plus selected observable managerial attributes. Model (2) adds firm fixed effects only to the benchmark model, Model (3) adds manager fixed effects only, and Model (4) includes both firm and manager fixed effects. We include year fixed effects in all specifications. We delete observations with missing values for RHS variables included in the benchmark specification, but include observations with missing values of tenure and age by using indicator variables for whether each is missing. Panel B uses the coefficient estimates in specification (4) of Panel A to decompose model R-squared in order to quantify the relative importance of each class of variable in determining the portion of delta explained. Refer to the Appendix for variable definitions. Heteroskedasticity robust t-statistics clustered at the firm level are in parenthesis. $* * *, * *$, and $*$ indicate significance at the 1,5 , and $10 \%$ levels, respectively.

\section{Panel A:}

Dependent variable: Delta

\begin{tabular}{|c|c|c|c|c|}
\hline & $\begin{array}{c}(1) \\
\text { Pooled OLS } \\
\text { (no firm or manager FE) }\end{array}$ & $\begin{array}{c}(2) \\
\text { Firm FE } \\
\text { (no manager FE) }\end{array}$ & $\begin{array}{c}\text { (3) } \\
\text { Manager FE } \\
\text { (no firm FE) }\end{array}$ & $\begin{array}{c}\text { (4) } \\
\text { Firm \& Manager } \\
\text { FE }\end{array}$ \\
\hline Tenure & $\begin{array}{c}0.011 * * * \\
(29.31)\end{array}$ & $\begin{array}{c}0.013 * * * \\
(30.97)\end{array}$ & $\begin{array}{c}0.007 * * * \\
(7.28)\end{array}$ & $\begin{array}{l}0.000 \\
(0.30)\end{array}$ \\
\hline Age & $\begin{array}{c}0.002 * * * \\
(6.28)\end{array}$ & $\begin{array}{c}0.004 * * * \\
(10.84)\end{array}$ & $\begin{array}{c}0.014 * * * \\
(11.24)\end{array}$ & $\begin{array}{c}0.015 * * * \\
(11.55)\end{array}$ \\
\hline Female & $\begin{array}{c}-0.031 * * * \\
(-3.44)\end{array}$ & $\begin{array}{c}-0.038 * * * \\
(-3.70)\end{array}$ & N/A & N/A \\
\hline CEO & $\begin{array}{c}0.248 * * * \\
(32.63)\end{array}$ & $\begin{array}{l}0.250 * * * \\
(35.08)\end{array}$ & $\begin{array}{c}0.095 * * * \\
(14.81)\end{array}$ & $\begin{array}{l}0.088 * * * \\
(13.22)\end{array}$ \\
\hline Director & $\begin{array}{l}0.220 * * * \\
(29.40)\end{array}$ & $\begin{array}{l}0.194 * * * \\
(26.69)\end{array}$ & $\begin{array}{c}0.076 * * * \\
(10.35)\end{array}$ & $\begin{array}{c}0.056^{* * * *} \\
(7.28)\end{array}$ \\
\hline Surplus Cash & $\begin{array}{c}-0.112 * * * \\
(-5.18)\end{array}$ & $\begin{array}{c}-0.130 * * * \\
(-4.94)\end{array}$ & $\begin{array}{c}-0.088 * * * \\
(-3.79)\end{array}$ & $\begin{array}{l}-0.050 * \\
(-1.80)\end{array}$ \\
\hline Leverage & $\begin{array}{c}-0.205 * * * \\
(-18.11)\end{array}$ & $\begin{array}{c}-0.140 * * * \\
(-8.59)\end{array}$ & $\begin{array}{c}-0.155 * * * \\
(-10.87)\end{array}$ & $\begin{array}{c}-0.152 * * * \\
(-10.24)\end{array}$ \\
\hline$R \& D$ & $\begin{array}{c}-0.049 * * \\
(-2.07)\end{array}$ & $\begin{array}{c}-0.147 * * * \\
(-3.48)\end{array}$ & $\begin{array}{c}-0.052 * * \\
(-1.96)\end{array}$ & $\begin{array}{c}-0.057 * * \\
(-1.97)\end{array}$ \\
\hline Market-to-Book & $\begin{array}{l}0.078 * * * \\
(70.15)\end{array}$ & $\begin{array}{l}0.074 * * * \\
(36.24)\end{array}$ & $\begin{array}{l}0.070 * * * \\
(42.65)\end{array}$ & $\begin{array}{l}0.070 * * * \\
(42.01)\end{array}$ \\
\hline Firm Risk & $\begin{array}{c}0.186 * * * \\
(11.21)\end{array}$ & $\begin{array}{c}-0.122 * * * \\
(-4.81)\end{array}$ & $\begin{array}{c}-0.071 * * * \\
(-3.97)\end{array}$ & $\begin{array}{c}-0.127 * * * \\
(-5.50)\end{array}$ \\
\hline $\begin{array}{l}\text { Board } \\
\text { Independence }\end{array}$ & $\begin{array}{c}-0.233 * * * \\
(-13.91)\end{array}$ & $\begin{array}{c}0.068 * * * \\
(3.27)\end{array}$ & $\begin{array}{l}0.005 \\
(0.33)\end{array}$ & $\begin{array}{l}0.010 \\
(0.81)\end{array}$ \\
\hline
\end{tabular}




\begin{tabular}{lcccc} 
Institutional & & & & \\
Holdings & $-0.001 * * *$ & -0.000 & -0.000 & -0.000 \\
& $(-5.33)$ & $(-0.66)$ & $(-0.58)$ & $(-0.18)$ \\
& & & & \\
Log(NetAssets) & $0.088^{* * *}$ & $0.098^{* * *}$ & $0.120^{* * *}$ & $0.152^{* * * *}$ \\
& $(60.57)$ & $(23.05)$ & $(38.80)$ & $(38.80)$ \\
Year FE & Yes & Yes & Yes & Yes \\
\hline Adjusted R $\mathrm{R}^{2}$ & 0.25 & 0.37 & 0.73 & 0.75 \\
$\mathrm{~N}$ & 83,670 & 83,670 & 83,670 & 83,670 \\
\hline
\end{tabular}

\section{Panel B:}

Relative Importance of Components in Determining Delta (Panel A, Model (4))

\begin{tabular}{lcc}
\hline & $\frac{\operatorname{cov}(\text { delta, component })}{\operatorname{var}(\text { delta })}$ & $\begin{array}{c}\% \text { of } \mathrm{R}^{2} \text { attributable } \\
\text { to the component }\end{array}$ \\
\hline $\begin{array}{l}\text { Observable Firm } \\
\text { Characteristics }\end{array}$ & 0.124 & $15.32 \%$ \\
$\begin{array}{l}\text { Observable Manager } \\
\text { Characteristics }\end{array}$ & 0.052 & $6.37 \%$ \\
Firm Fixed Effects & 0.031 & $3.80 \%$ \\
Manager Fixed Effects & 0.598 & $73.28 \%$ \\
Year Fixed Effects & 0.010 & $1.23 \%$ \\
Residual & 0.186 & \\
\hline
\end{tabular}


Table 4

Observable and Unobservable Determinants of Vega - Connectedness Sample with AKM Method

This table presents the results for specifications regressing managerial vega on observable managerial and firm characteristics and on various combinations of fixed effects that proxy for time and for unobserved manager and firm attributes. The benchmark specification (model (1) in Panel A) is a pooled OLS regression, without firm or manager fixed effects (FE), which is based on the explanatory variables in Table 3, Panel A, Column 2 in Coles, Daniel, and Naveen (2006) plus selected observable managerial attributes. Model (2) adds firm fixed effects only to the benchmark model, Model (3) adds manager fixed effects only, and Model (4) includes both firm and manager fixed effects. We include year fixed effects in all specifications. We delete observations with missing values for RHS variables included in the benchmark specification, but include observations with missing values of tenure and age by using indicator variables for whether each is missing. Panel B uses the coefficient estimates in specification (4) of Panel A to decompose model R-squared in order to quantify the relative importance of each class of variable in determining the portion of vega explained. Refer to the Appendix for variable definitions. Heteroskedasticity robust t-statistics clustered at the firm level are in parenthesis. ${ }^{* *}, * *$, and $*$ indicate significance at the 1,5 , and $10 \%$ levels, respectively.

\section{Dependent variable: Vega}

\begin{tabular}{cccc}
$\begin{array}{c}(1) \\
\text { Pooled OLS }\end{array}$ & $\begin{array}{c}(2) \\
\text { Firm FE } \\
\text { (no manager FE) }\end{array}$ & $\begin{array}{c}(3) \\
\text { Manager FE } \\
\text { (no firm FE) }\end{array}$ & $\begin{array}{c}(4) \\
\text { Firm \& Manager } \\
\text { FE }\end{array}$ \\
\hline $0.001 * * *$ & $0.001 * * *$ & $0.001 * * *$ & $0.001 * * *$
\end{tabular}

\begin{tabular}{|c|c|c|c|c|}
\hline Tenure & $\begin{array}{c}0.001 * * * \\
(5.14)\end{array}$ & $\begin{array}{c}0.001 * * * \\
(7.25)\end{array}$ & $\begin{array}{c}0.001 * * * \\
(4.16)\end{array}$ & $\begin{array}{c}0.001 * * * \\
(4.15)\end{array}$ \\
\hline Age & $\begin{array}{c}-0.001 * * * \\
(-8.89)\end{array}$ & $\begin{array}{c}-0.000 * * * \\
(-5.17)\end{array}$ & $\begin{array}{c}0.001 * * * \\
(4.13)\end{array}$ & $\begin{array}{c}0.001 * * * \\
(3.90)\end{array}$ \\
\hline Female & $\begin{array}{l}-0.005 \\
(-1.04)\end{array}$ & $\begin{array}{c}-0.005^{* * * *} \\
(-3.20)\end{array}$ & N/A & N/A \\
\hline CEO & $\begin{array}{c}0.045^{* * *} * \\
(36.25)\end{array}$ & $\begin{array}{c}0.045^{* * * *} \\
(37.01)\end{array}$ & $\begin{array}{c}0.029 * * * \\
(17.68)\end{array}$ & $\begin{array}{c}0.029 * * * \\
(15.87)\end{array}$ \\
\hline Director & $\begin{array}{c}0.027 * * * \\
(24.17)\end{array}$ & $\begin{array}{c}0.028 * * * \\
(23.51)\end{array}$ & $\begin{array}{c}0.024 * * * \\
(14.08)\end{array}$ & $\begin{array}{c}0.024 * * * \\
(12.00)\end{array}$ \\
\hline Surplus Cash & $\begin{array}{c}0.014 * * * \\
(4.06)\end{array}$ & $\begin{array}{l}-0.010^{*} \\
(-1.90)\end{array}$ & $\begin{array}{l}0.002 \\
(0.68)\end{array}$ & $\begin{array}{l}0.000 \\
(0.11)\end{array}$ \\
\hline Leverage & $\begin{array}{c}-0.035^{* * * *} \\
(-16.87)\end{array}$ & $\begin{array}{c}-0.015^{* * *} \\
(-5.56)\end{array}$ & $\begin{array}{c}-0.017 \text { *** } \\
(-5.22)\end{array}$ & $\begin{array}{c}-0.015 * * * \\
(-4.98)\end{array}$ \\
\hline$R \& D$ & $\begin{array}{c}0.090 * * * \\
(19.76)\end{array}$ & $\begin{array}{l}0.007 \\
(0.90)\end{array}$ & $\begin{array}{l}-0.006 \\
(-0.87)\end{array}$ & $\begin{array}{l}-0.006 \\
(-0.92)\end{array}$ \\
\hline Market-to-Book & $\begin{array}{c}0.008 * * * \\
(33.47)\end{array}$ & $\begin{array}{c}0.001 * * * \\
(3.15)\end{array}$ & $\begin{array}{l}0.000 \\
(0.10)\end{array}$ & $\begin{array}{c}-0.001 * * \\
(-2.33)\end{array}$ \\
\hline Firm Risk & $\begin{array}{l}0.008 \\
(1.49)\end{array}$ & $\begin{array}{c}-0.050^{* * * *} \\
(-12.18)\end{array}$ & $\begin{array}{c}-0.042 * * * \\
(-7.70)\end{array}$ & $\begin{array}{c}-0.042 * * * \\
(-7.81)\end{array}$ \\
\hline $\begin{array}{l}\text { Board } \\
\text { Independence }\end{array}$ & $\begin{array}{c}0.013 * * * \\
(4.63)\end{array}$ & $\begin{array}{c}0.015 * * * \\
(4.52)\end{array}$ & $\begin{array}{c}0.015 * * * \\
(3.88)\end{array}$ & $\begin{array}{c}0.016^{* * * *} \\
(4.10)\end{array}$ \\
\hline Institutional & $-0.000^{* * *}$ & -0.000 & -0.000 & 0.000 \\
\hline
\end{tabular}




\begin{tabular}{lcccc} 
Holdings & $(-2.77)$ & $(-0.94)$ & $(-0.73)$ & $(0.57)$ \\
& & & & \\
Log (NetAssets) & $(98.01)$ & $0.025^{* * *}$ & $0.022^{* * * *}$ & $(23.68)$ \\
& Yes & $(35.91)$ & Yes & Yes \\
Year FE & 0.28 & 0.40 & 0.47 & 0.49 \\
Adjusted R & & & 83,670 & 83,670 \\
$\mathrm{~N}$ & 83,670 & 83,670 & 83.670 \\
\hline
\end{tabular}

\section{Panel B:}

Relative Importance of Components in Determining Vega (Panel A, Model (4))

\begin{tabular}{lcc}
\hline & $\frac{\operatorname{cov}(\text { vega,component })}{\operatorname{var}(\text { vega })}$ & $\begin{array}{c}\% \text { of } \mathrm{R}^{2} \text { attributable } \\
\text { to the component }\end{array}$ \\
\hline $\begin{array}{l}\text { Observable Firm } \\
\begin{array}{l}\text { Characteristics } \\
\text { Observable Manager } \\
\text { Characteristics }\end{array}\end{array}$ & 0.121 & $19.32 \%$ \\
Firm Fixed Effects & 0.058 & $9.27 \%$ \\
Manager Fixed Effects & 0.048 & $7.67 \%$ \\
Year Fixed Effects & 0.370 & $59.10 \%$ \\
Residual & 0.029 & $4.62 \%$ \\
\hline
\end{tabular}


Table 5

Observable and Unobservable Determinants of Executive Pay Level - Connectedness Sample with AKM Method

This table presents the results for specifications regressing executive total compensation on observable managerial and firm characteristics and on various combinations of fixed effects that proxy for time and for unobserved manager and firm attributes. The benchmark specification (model (1) in Panel A) is a pooled OLS regression, without firm or manager fixed effects (FE), which is based on the explanatory variables in Table 4, Panel A, Column 1 in Graham, Li, and Qiu (2011) plus selected observable managerial attributes. Model (2) adds firm fixed effects only to the benchmark model, Model (3) adds manager fixed effects only, and Model (4) includes both firm and manager fixed effects. We include year fixed effects in all specifications. We delete observations with missing values for RHS variables included in the benchmark specification, but include observations with missing values of tenure and age by using indicator variables for whether each is missing. Panel B uses the coefficient estimates in specification (4) of Panel A to decompose model R-squared in order to quantify the relative importance of each class of variable in determining the portion of pay level explained. Refer to the Appendix for variable definitions. Heteroskedasticity robust t-statistics clustered at the firm level are in parenthesis. $* * *, * *$, and * indicate significance at the 1,5 , and $10 \%$ levels, respectively.

Panel A:

Dependent variable: Total Compensation

\begin{tabular}{|c|c|c|c|c|}
\hline & $\begin{array}{c}(1) \\
\text { Pooled OLS } \\
\text { (no firm or manager FE) }\end{array}$ & $\begin{array}{c}(2) \\
\text { Firm FE } \\
\text { (no manager FE) }\end{array}$ & $\begin{array}{c}(3) \\
\text { Manager FE } \\
\text { (no firm FE) }\end{array}$ & $\begin{array}{c}\text { (4) } \\
\text { Firm \& } \\
\text { Manager FE }\end{array}$ \\
\hline Tenure & $\begin{array}{c}-0.016^{* * *} \\
(-9.16)\end{array}$ & $\begin{array}{c}-0.007 * * * \\
(-3.44)\end{array}$ & $\begin{array}{c}-0.014 * * * \\
(-2.41)\end{array}$ & $\begin{array}{l}0.001 \\
(0.08)\end{array}$ \\
\hline Age & $\begin{array}{c}-0.010 * * * \\
(-6.90)\end{array}$ & $\begin{array}{c}-0.009 * * * \\
(-3.46)\end{array}$ & $\begin{array}{l}0.058 * * * \\
\quad(5.94)\end{array}$ & $\begin{array}{l}0.053 * * * \\
(5.42)\end{array}$ \\
\hline Female & $\begin{array}{l}-0.028 \\
(-0.82)\end{array}$ & $\begin{array}{c}-0.187 * * * \\
(-3.54)\end{array}$ & N/A & N/A \\
\hline CEO & $\begin{array}{l}1.912 * * * \\
(46.93)\end{array}$ & $\begin{array}{c}1.830 * * * \\
(45.78)\end{array}$ & $\begin{array}{c}0.957 * * * \\
(18.40)\end{array}$ & $\begin{array}{l}0.872 * * * \\
(16.09)\end{array}$ \\
\hline Director & $\begin{array}{l}1.341 * * * \\
(35.14)\end{array}$ & $\begin{array}{c}1.340 * * * \\
(34.79)\end{array}$ & $\begin{array}{l}1.322 * * * \\
(22.76)\end{array}$ & $\begin{array}{l}1.180 * * * \\
(19.72)\end{array}$ \\
\hline Surplus Cash & $\begin{array}{l}0.201 \\
(1.19)\end{array}$ & $\begin{array}{c}-0.481 * * * \\
(-3.06)\end{array}$ & $\begin{array}{l}-0.155 \\
(-0.85)\end{array}$ & $\begin{array}{l}-0.221 \\
(-1.09)\end{array}$ \\
\hline Leverage & $\begin{array}{c}-1.170 * * * \\
(-16.57)\end{array}$ & $\begin{array}{c}-1.081 * * * \\
(-12.43)\end{array}$ & $\begin{array}{c}-1.022 * * * \\
(-9.83)\end{array}$ & $\begin{array}{c}-1.022 * * * \\
(-9.81)\end{array}$ \\
\hline$R \& D$ & $\begin{array}{c}2.149 * * * \\
(12.81)\end{array}$ & $\begin{array}{l}-0.181 \\
(-0.88)\end{array}$ & $\begin{array}{l}-0.281 \\
(-1.10)\end{array}$ & $\begin{array}{l}-0.334 \\
(-1.29)\end{array}$ \\
\hline Q & $\begin{array}{l}0.495 * * * \\
(56.92)\end{array}$ & $\begin{array}{c}0.465 * * * \\
(35.12)\end{array}$ & $\begin{array}{l}0.481 * * * \\
(36.12)\end{array}$ & $\begin{array}{c}0.499 * * * \\
(36.42)\end{array}$ \\
\hline Firm Risk & $\begin{array}{c}3.077 * * * \\
(31.01)\end{array}$ & $\begin{array}{c}1.080 * * * \\
(7.73)\end{array}$ & $\begin{array}{c}2.522 * * * \\
(14.30)\end{array}$ & $\begin{array}{c}2.057 * * * \\
(10.54)\end{array}$ \\
\hline $\begin{array}{l}\text { Board } \\
\text { Independence }\end{array}$ & $\begin{array}{c}0.172 * \\
(1.99)\end{array}$ & $\begin{array}{c}0.452 * * * \\
(3.80)\end{array}$ & $\begin{array}{c}0.391 * * * \\
(3.11)\end{array}$ & $\begin{array}{c}0.507 * * * \\
(3.84)\end{array}$ \\
\hline
\end{tabular}




\begin{tabular}{lcccc} 
Institutional & & & \\
Holdings & -0.001 & -0.000 & 0.002 & $0.002^{*}$ \\
& $(-1.17)$ & $(-0.09)$ & $(0.81)$ & $(1.82)$ \\
& & & & \\
Log(NetAssets) & $1.060^{* * *}$ & $1.088^{* * *}$ & $0.924^{* * *}$ & $1.018^{* * * *}$ \\
& $(126.06)$ & $(44.98)$ & $(37.37)$ & $(31.85)$ \\
Year FE & Yes & Yes & Yes & Yes \\
\hline Adjusted R & 0.35 & 0.47 & 0.64 & 0.67 \\
$\mathrm{~N}$ & 83,670 & 83,670 & 83,670 & 83,670 \\
\hline
\end{tabular}

\section{Panel B:}

Relative Importance of Components in Determining Pay Level

\begin{tabular}{lcc}
\hline & $\frac{\operatorname{cov}(\text { PayLevel,component })}{\operatorname{var}(\text { PayLevel })}$ & $\begin{array}{c}\% \text { of } \mathrm{R}^{2} \text { attributable } \\
\text { to the component }\end{array}$ \\
\hline $\begin{array}{l}\text { Observable Firm } \\
\text { Characteristics }\end{array}$ & 0.150 & $20.19 \%$ \\
$\begin{array}{l}\text { Observable Manager } \\
\text { Firm Fixed Effistics }\end{array}$ & 0.081 & $10.90 \%$ \\
Manager Fixed Effects & 0.062 & $8.34 \%$ \\
Year Fixed Effects & 0.350 & $47.10 \%$ \\
Residual & 0.101 & $13.82 \%$ \\
\hline
\end{tabular}


Table 6

Observable and Unobservable Determinants of Board Independence - Connectedness Sample with AKM Method

This table presents the results for specifications regressing board independence on observable managerial and firm characteristics and on various combinations of fixed effects that proxy for time and for unobserved manager and firm attributes. The benchmark specification (model (1) in Panel A) is a pooled OLS regression, without firm or manager fixed effects (FE), which is based on the explanatory variables in Table 4, Column 2 in Linck, Netter, and Yang (2008) plus selected observable managerial attributes. Model (2) adds firm fixed effects only to the benchmark model, Model (3) adds manager fixed effects only, and Model (4) includes both firm and manager fixed effects. We include year fixed effects in all specifications. We delete observations with missing values for RHS variables included in the benchmark specification, but include observations with missing values of tenure and age by using indicator variables for whether each is missing. Panel B uses the coefficient estimates in specification (4) of Panel A to decompose model R-squared in order to quantify the relative importance of each class of variable in determining the portion of board independence explained. Refer to the Appendix for variable definitions. Heteroskedasticity robust t-statistics clustered at the firm level are in parenthesis. $* * * * *$, and $*$ indicate significance at the 1,5 , and $10 \%$ levels, respectively.

Panel A:

Dependent variable: Board Independence

\begin{tabular}{|c|c|c|c|c|}
\hline & $\begin{array}{c}(1) \\
\text { Pooled OLS } \\
\text { (no firm or manager FE) }\end{array}$ & $\begin{array}{c}(2) \\
\text { Firm FE } \\
\text { (no manager FE) }\end{array}$ & $\begin{array}{c}(3) \\
\text { Manager FE } \\
\text { (no firm FE) }\end{array}$ & $\begin{array}{c}(4) \\
\text { Firm \& Manager } \\
\text { FE }\end{array}$ \\
\hline \multirow[t]{2}{*}{ LogMVE } & $0.014 * * *$ & $0.012 * * *$ & $0.008 * * *$ & $0.008 * * *$ \\
\hline & 17.12 & 8.58 & 5.24 & 5.08 \\
\hline \multirow[t]{2}{*}{ Debt } & $0.037 * * *$ & $-0.010 *$ & $-0.019 * *$ & $-0.019 * *$ \\
\hline & 6.24 & -1.69 & -2.53 & -2.51 \\
\hline \multirow[t]{2}{*}{ Log(Segments) } & $0.018 * * *$ & $0.016 * * *$ & $0.016 * * *$ & $0.015 * * *$ \\
\hline & 13.81 & 10.08 & 8.40 & 7.66 \\
\hline \multirow[t]{2}{*}{ FirmAge } & $-0.008 * * *$ & N/A & $0.005 * * *$ & N/A \\
\hline & -13.45 & & 2.73 & \\
\hline \multirow[t]{2}{*}{ FirmAge $^{\wedge} 2$} & $0.000 * * *$ & N/A & $-0.000 * *$ & N/A \\
\hline & 16.90 & & -1.97 & \\
\hline \multirow[t]{2}{*}{ MTB } & $-0.009 * * *$ & $-0.003 * * *$ & -0.001 & -0.000 \\
\hline & -12.11 & -4.21 & -1.10 & -0.63 \\
\hline \multirow[t]{2}{*}{$\mathrm{R} \& \mathrm{D}$} & $0.093 * * *$ & 0.021 & -0.025 & 0.014 \\
\hline & 5.07 & 0.81 & -0.85 & 0.45 \\
\hline \multirow[t]{2}{*}{ RETSTD } & $-0.051 * * *$ & $-0.015 * * *$ & $-0.028 * * *$ & $-0.025 * * *$ \\
\hline & -8.44 & -3.71 & -4.93 & -3.94 \\
\hline \multirow[t]{2}{*}{ CEO_Own } & $-0.433 * * *$ & 0.000 & 0.012 & -0.011 \\
\hline & -10.35 & 0.00 & 0.33 & -0.19 \\
\hline \multirow[t]{2}{*}{ Director_Own } & $0.568 * * *$ & $0.340 * * *$ & $0.358 * * *$ & $0.330 * * *$ \\
\hline & 47.72 & 31.55 & 27.70 & 25.73 \\
\hline \multirow[t]{2}{*}{ FCF } & $0.144 * * *$ & $0.024 * *$ & 0.004 & 0.004 \\
\hline & 12.32 & 2.68 & 0.46 & 0.45 \\
\hline
\end{tabular}




\begin{tabular}{|c|c|c|c|c|}
\hline Performance & $\begin{array}{c}-0.054 * * * \\
-6.50\end{array}$ & $\begin{array}{l}-0.008 \\
-0.77\end{array}$ & $\begin{array}{c}-0.013^{*} \\
-1.66\end{array}$ & $\begin{array}{c}-0.013 * \\
-1.66\end{array}$ \\
\hline Lag(CEO_Chair) & $\begin{array}{c}0.049 * * * \\
23.00\end{array}$ & $\begin{array}{c}0.023 * * * \\
12.04\end{array}$ & $\begin{array}{c}0.022^{* * *} \\
10.32\end{array}$ & $\begin{array}{c}0.018^{* * * *} \\
8.75\end{array}$ \\
\hline Age & $\begin{array}{c}0.000 \\
0.85\end{array}$ & $\begin{array}{c}0.000^{*} \\
1.82\end{array}$ & $\begin{array}{c}0.002 * * * \\
2.78\end{array}$ & $\begin{array}{c}0.002 * * * \\
2.74\end{array}$ \\
\hline Tenure & $\begin{array}{c}-0.001 * * * * \\
-3.40\end{array}$ & $\begin{array}{c}0.000 \\
0.05\end{array}$ & $\begin{array}{c}-0.000 \\
-0.79\end{array}$ & $\begin{array}{l}-0.000 \\
-0.20\end{array}$ \\
\hline Female & $\begin{array}{l}-0.003 \\
-0.99\end{array}$ & $\begin{array}{l}-0.001 \\
-0.33\end{array}$ & N/A & N/A \\
\hline Mover & $\begin{array}{c}0.015^{* * *} \\
5.84\end{array}$ & $\begin{array}{c}0.005^{* * *} \\
3.89\end{array}$ & N/A & N/A \\
\hline CEO & $\begin{array}{c}0.071^{* * *} \\
21.10\end{array}$ & $\begin{array}{c}0.018^{* * *} \\
7.94\end{array}$ & $\begin{array}{c}0.013 * * * \\
4.00\end{array}$ & $\begin{array}{c}0.012 * * * \\
3.51\end{array}$ \\
\hline Director & $\begin{array}{c}-0.057 * * * \\
-17.55\end{array}$ & $\begin{array}{c}-0.028 * * * \\
-11.25\end{array}$ & $\begin{array}{c}-0.039 * * * \\
-11.44\end{array}$ & $\begin{array}{c}-0.036 * * * \\
-10.37\end{array}$ \\
\hline Year Fixed Effects & Yes & Yes & Yes & Yes \\
\hline Adjusted $\mathrm{R}^{2}$ & 0.25 & 0.73 & 0.73 & 0.75 \\
\hline $\mathrm{N}$ & 36,745 & 36,745 & 36,745 & 36,745 \\
\hline
\end{tabular}

\section{Panel B:}

Relative Importance of Components in Determining Board Independence

\begin{tabular}{lcc}
\hline & $\begin{array}{cc}\operatorname{cov}(\text { BoardIndependence,component }) \\
\operatorname{var}(\text { Boardindependence })\end{array}$ & $\begin{array}{c}\% \text { of } \mathrm{R}^{2} \text { attributable } \\
\text { to the component }\end{array}$ \\
\hline $\begin{array}{l}\text { Observable Firm } \\
\text { Characteristics }\end{array}$ & 0.022 & $2.63 \%$ \\
$\begin{array}{l}\text { Observable Manager } \\
\text { Characteristics }\end{array}$ & 0.007 & $0.84 \%$ \\
Firm Fixed Effects & 0.228 & $27.44 \%$ \\
Manager Fixed Effects & 0.514 & $59.70 \%$ \\
Year Fixed Effects & 0.060 & $7.22 \%$ \\
Residual & 0.169 & \\
\hline
\end{tabular}


Table 7

Observable and Unobservable Determinants of Board Size - Connectedness Sample with AKM Method

This table presents the results for specifications regressing board size on observable managerial and firm characteristics and on various combinations of fixed effects that proxy for time and for unobserved manager and firm attributes. The benchmark specification (model (1) in Panel A) is a pooled OLS regression, without firm or manager fixed effects (FE), which is based on the explanatory variables in Table 4, Column 1 in Linck, Netter, and Young (2008) plus selected observable managerial attributes. Model (2) adds firm fixed effects only to the benchmark model, Model (3) adds manager fixed effects only, and Model (4) includes both firm and manager fixed effects. We include year fixed effects in all specifications. We delete observations with missing values for RHS variables included in the benchmark specification, but include observations with missing values of tenure and age by using indicator variables for whether each is missing. Panel B uses the coefficient estimates in specification (4) of Panel A to decompose model R-squared in order to quantify the relative importance of each class of variable in determining the portion of board size explained. Refer to the Appendix for variable definitions. Heteroskedasticity robust t-statistics clustered at the firm level are in parenthesis. $* * *, * *$, and $*$ indicate significance at the 1,5 , and $10 \%$ levels, respectively.

Panel A:

Dependent variable: Board Size

\begin{tabular}{|c|c|c|c|c|}
\hline & $\begin{array}{c}(1) \\
\text { Pooled OLS } \\
\text { (no firm or manager FE) }\end{array}$ & $\begin{array}{c}\text { (2) } \\
\text { Firm FE } \\
\text { (no manager FE) }\end{array}$ & $\begin{array}{c}\text { (3) } \\
\text { Manager FE } \\
\text { (no firm FE) }\end{array}$ & $\begin{array}{c}\text { (4) } \\
\text { Firm \& Manager } \\
\text { FE }\end{array}$ \\
\hline LogMVE & $\begin{array}{c}0.591 * * * \\
59.07\end{array}$ & $\begin{array}{c}0.270^{* * *} \\
14.22\end{array}$ & $\begin{array}{c}0.341 * * * \\
15.70\end{array}$ & $\begin{array}{c}0.233^{* * *} \\
9.75\end{array}$ \\
\hline Debt & $\begin{array}{c}1.217 * * * \\
15.94\end{array}$ & $\begin{array}{c}0.031 \\
0.30\end{array}$ & $\begin{array}{l}0.272 * * * \\
2.55\end{array}$ & $\begin{array}{c}0.080 \\
0.73\end{array}$ \\
\hline $\log ($ Segments $)$ & $\begin{array}{l}0.214 * * * \\
11.85\end{array}$ & $\begin{array}{l}0.118 * * * \\
5.30\end{array}$ & $\begin{array}{c}0.133 * * * \\
5.08\end{array}$ & $\begin{array}{c}0.118^{* * *} \\
4.40\end{array}$ \\
\hline FirmAge & $\begin{array}{c}-0.112 * * * \\
-11.81\end{array}$ & N/A & $\begin{array}{c}0.050 \\
0.97\end{array}$ & N/A \\
\hline FirmAge $^{\wedge} 2$ & $\begin{array}{c}0.003^{* * * *} \\
16.89\end{array}$ & N/A & $\begin{array}{c}0.001 \\
1.30\end{array}$ & N/A \\
\hline МТВ & $\begin{array}{c}-0.259 * * * \\
-24.08\end{array}$ & $\begin{array}{c}-0.156 * * * \\
-15.90\end{array}$ & $\begin{array}{c}-0.157 * * * \\
-12.08\end{array}$ & $\begin{array}{c}-0.122 * * * \\
-9.58\end{array}$ \\
\hline $\mathrm{R} \& \mathrm{D}$ & $\begin{array}{c}-2.651 * * * \\
-11.75\end{array}$ & $\begin{array}{c}0.258 \\
0.68\end{array}$ & $\begin{array}{c}0.263 \\
0.66\end{array}$ & $\begin{array}{c}0.151 \\
0.30\end{array}$ \\
\hline RETSTD & $\begin{array}{l}-1.066^{* * *} \\
-13.80\end{array}$ & $\begin{array}{c}-0.438 * * * \\
-6.81\end{array}$ & $\begin{array}{c}-0.418 * * * \\
-5.02\end{array}$ & $\begin{array}{c}-0.321 * * * \\
-4.50\end{array}$ \\
\hline CEO_Own & $\begin{array}{c}-3.047 * * * \\
-5.32\end{array}$ & $\begin{array}{c}-0.846 * * \\
-2.50\end{array}$ & $\begin{array}{c}-1.660 * * * \\
-2.86\end{array}$ & $\begin{array}{c}-1.137 * \\
-1.82\end{array}$ \\
\hline Director_Own & $\begin{array}{c}-3.142 * * * \\
-18.72\end{array}$ & $\begin{array}{c}-2.248^{* * *} \\
-14.37\end{array}$ & $\begin{array}{c}-2.332 * * * \\
-12.54\end{array}$ & $\begin{array}{c}-2.177 * * * \\
-12.10\end{array}$ \\
\hline Age & $\begin{array}{c}0.008 * * * \\
3.51\end{array}$ & $\begin{array}{c}0.003 \\
1.45\end{array}$ & $\begin{array}{c}0.003 \\
0.51\end{array}$ & $\begin{array}{l}-0.004 \\
-0.84\end{array}$ \\
\hline Tenure & $0.017 * * *$ & $0.005^{* * *}$ & $0.030 * * *$ & $0.077 * * *$ \\
\hline
\end{tabular}




\begin{tabular}{lcccc} 
& 5.54 & 3.41 & 4.55 & 8.70 \\
Female & $0.240^{* * *}$ & & N/A & N/A \\
& 4.58 & 0.027 & & N/A \\
Mover & 0.028 & 0.50 & N/A & \\
& 0.88 & 0.029 & & $-0.277^{* * *}$ \\
CEO & $-0.455^{* * *}$ & $-0.141^{* * *}$ & $-0.320^{* * * *}$ & -6.16 \\
& -9.83 & -5.17 & -6.97 & $0.319 * * *$ \\
Director & $0.434^{* * *}$ & $0.093^{* * *}$ & $0.167 * * *$ & 6.77 \\
& 10.54 & 3.81 & 3.60 & Yes \\
Year Fixed Effects & Yes & Yes & Yes & 0.80 \\
\hline Adjusted $\mathrm{R}^{2}$ & 0.39 & 0.79 & 0.78 & 36,745 \\
$\mathrm{~N}$ & 36,745 & 36,745 & 36,745 & \\
\hline
\end{tabular}

Panel B:

Relative Importance of Components in Determining Board Size

\begin{tabular}{lcc}
\hline & $\frac{\operatorname{cov}(\text { BoardSize,component })}{\operatorname{var}(\text { BoardSize })}$ & $\begin{array}{c}\% \text { of } \mathrm{R}^{2} \text { attributable } \\
\text { to the component }\end{array}$ \\
\hline $\begin{array}{l}\text { Observable Firm } \\
\begin{array}{l}\text { Obaracteristics } \\
\text { Observable Manager }\end{array}\end{array}$ & 0.086 & $9.81 \%$ \\
$\quad$ Firm Fixed Effects & 0.044 & $5.02 \%$ \\
Manager Fixed Effects & 0.270 & $30.82 \%$ \\
Year Fixed Effects & 0.460 & $52.50 \%$ \\
Residual & 0.016 & $1.82 \%$ \\
\hline
\end{tabular}


Table 8

Observable and Unobservable Determinants of Board Leadership - Connectedness Sample with AKM Method

This table presents the results for specifications regressing board leadership (i.e., CEO/Chair duality) on observable managerial and firm characteristics and on various combinations of fixed effects that proxy for time and for unobserved manager and firm attributes. The benchmark specification (model (1) in Panel A) is a logistic regression, without firm or manager fixed effects (FE), which is based on the explanatory variables in Table 4, Column 3 in Linck, Netter, and Young (2008) plus selected observable managerial attributes. Model (2) adds firm fixed effects only to the benchmark model, Model (3) adds manager fixed effects only, Model (4) includes both firm and manager fixed effects, and Model (5) is a linear probability model (LPM) with both firm and manager fixed effects. We include year fixed effects in all specifications. We delete observations with missing values for RHS variables included in the benchmark specification, but include observations with missing values of tenure and age by using indicator variables for whether each is missing. Panel B uses the coefficient estimates in specification (5) of Panel A to decompose model R-squared in order to quantify the relative importance of each class of variable in determining the portion of board leadership explained. Refer to the Appendix for variable definitions. Heteroskedasticity robust $\mathrm{t}$-statistics clustered at the firm level are in parenthesis. $* * *$, $* *$, and $*$ indicate significance at the 1,5 , and $10 \%$ levels, respectively.

Panel A:

Dependent variable: Board Leadership

\begin{tabular}{|c|c|c|c|c|c|}
\hline & $\begin{array}{c}\text { (1) } \\
\text { Logistic } \\
\text { (no firm or } \\
\text { manager FE) }\end{array}$ & $\begin{array}{c}\text { (2) } \\
\text { Logistic } \\
\text { Firm FE } \\
\text { (no manager FE) }\end{array}$ & $\begin{array}{c}(3) \\
\text { Logistic } \\
\text { Manager FE } \\
\text { (no firm FE) }\end{array}$ & $\begin{array}{c}(4) \\
\text { Logistic } \\
\text { Firm \& } \\
\text { Manager FE }\end{array}$ & $\begin{array}{c}\text { (5) } \\
\text { LPM } \\
\text { Firm \& } \\
\text { Manager FE }\end{array}$ \\
\hline LogMVE & $\begin{array}{c}0.340 * * * \\
26.22\end{array}$ & $\begin{array}{c}0.175^{* * * *} \\
\quad 3.02\end{array}$ & $\begin{array}{c}0.306^{* * * *} \\
4.18\end{array}$ & $\begin{array}{c}0.135 \\
1.40\end{array}$ & $\begin{array}{c}0.025 * * * \\
4.11\end{array}$ \\
\hline MTB & $\begin{array}{c}-0.224 * * * \\
-15.51\end{array}$ & $\begin{array}{c}-0.110 * * * \\
-3.47\end{array}$ & $\begin{array}{c}-0.228 * * * \\
-5.49\end{array}$ & $\begin{array}{c}-0.118 * * * \\
-2.42\end{array}$ & $\begin{array}{c}-0.011 * * * \\
-3.25\end{array}$ \\
\hline R\&D & $\begin{array}{c}0.167 \\
0.24\end{array}$ & $\begin{array}{c}0.841 \\
0.55\end{array}$ & $\begin{array}{c}1.448 \\
1.22\end{array}$ & $\begin{array}{c}2.837 * \\
1.89\end{array}$ & $\begin{array}{c}0.184^{*} \\
1.80\end{array}$ \\
\hline RETSTD & $\begin{array}{c}-0.624 * * * \\
-5.84\end{array}$ & $\begin{array}{c}-0.343 \\
-1.21\end{array}$ & $\begin{array}{c}-0.357 \\
-1.07\end{array}$ & $\begin{array}{c}-0.288 \\
-0.75\end{array}$ & $\begin{array}{c}0.006 \\
0.27\end{array}$ \\
\hline Performance & $\begin{array}{c}-0.497 * * * \\
-4.14\end{array}$ & $\begin{array}{c}-1.384 * * * \\
-5.33\end{array}$ & $\begin{array}{c}-1.509 * * * \\
-4.87\end{array}$ & $\begin{array}{c}-1.261 * * * \\
-3.10\end{array}$ & $\begin{array}{c}-0.059 * * * \\
-2.90\end{array}$ \\
\hline Age & $\begin{array}{c}0.002 \\
0.45\end{array}$ & $\begin{array}{c}0.011 * * \\
2.36\end{array}$ & $\begin{array}{c}0.016 \\
0.77\end{array}$ & $\begin{array}{c}0.016 \\
0.50\end{array}$ & $\begin{array}{c}0.003 \\
0.52\end{array}$ \\
\hline Tenure & $\begin{array}{c}0.002 \\
0.19\end{array}$ & $\begin{array}{c}-0.000 \\
-0.00\end{array}$ & $\begin{array}{c}0.017 \\
0.85\end{array}$ & $\begin{array}{c}0.002 \\
0.33\end{array}$ & $\begin{array}{c}0.001 \\
0.62\end{array}$ \\
\hline Female & $\begin{array}{c}0.242^{* * *} * \\
2.88\end{array}$ & $\begin{array}{c}0.070 \\
0.51\end{array}$ & N/A & N/A & N/A \\
\hline Mover & $\begin{array}{c}0.145^{* * * *} \\
3.73\end{array}$ & $\begin{array}{c}-0.023 \\
-0.33\end{array}$ & N/A & N/A & N/A \\
\hline CEO & $\begin{array}{c}0.155^{* *} * \\
2.74\end{array}$ & $\begin{array}{c}0.097 \\
1.11\end{array}$ & $\begin{array}{c}0.080 \\
0.41\end{array}$ & $\begin{array}{c}0.190 \\
1.04\end{array}$ & $\begin{array}{c}0.002 \\
0.18\end{array}$ \\
\hline Director & $\begin{array}{c}-0.008 \\
-0.00\end{array}$ & $\begin{array}{c}-0.301 * * * \\
-3.44\end{array}$ & $\begin{array}{c}-0.990 * * * \\
-5.73\end{array}$ & $\begin{array}{c}-0.834 * * * \\
-4.54\end{array}$ & $\begin{array}{c}-0.079 * * * \\
-4.55\end{array}$ \\
\hline
\end{tabular}




\begin{tabular}{lccccc} 
Year FE & Yes & Yes & Yes & Yes & Yes \\
\hline Adjusted R & 0.08 & 0.62 & 0.65 & 0.68 & 0.48 \\
$\mathrm{~N}$ & & & & & 30,891 \\
\hline
\end{tabular}

\section{Panel B:}

Relative Importance of Components in Determining Board Leadership

\begin{tabular}{lcc}
\hline & $\frac{\operatorname{cov}(\text { BoardLeadership,component })}{\operatorname{var}(\text { BoardLeadership })}$ & $\begin{array}{c}\% \text { of } \mathrm{R}^{2} \text { attributable } \\
\text { to the component }\end{array}$ \\
\hline $\begin{array}{l}\text { Observable Firm } \\
\begin{array}{l}\text { Characteristics } \\
\text { Observable Manager }\end{array}\end{array}$ & 0.060 & $9.23 \%$ \\
Characteristics & 0.005 & $0.78 \%$ \\
Firm Fixed Effects & 0.202 & $31.08 \%$ \\
Manager Fixed Effects & 0.363 & $55.85 \%$ \\
Year Fixed Effects & 0.020 & $3.08 \%$ \\
Residual & 0.350 & \\
\hline
\end{tabular}


Table 9

Observable and Unobservable Determinants of Bidder Dummy - Connectedness Sample with AKM Method

This table presents the results for specifications regressing bidder dummy on observable managerial and firm characteristics and on various combinations of fixed effects that proxy for time and for unobserved manager and firm attributes. The dependent variable is one if the firm announces a bid in year $t$ and zero otherwise. The benchmark specification (model (1) in Panel A) is a probit regression, without firm or manager fixed effects (FE), which is based on the explanatory variables in Table III, Column 3 in Harford (1999) plus selected observable managerial attributes. Model (2) adds firm fixed effects only to the benchmark model, Model (3) adds manager fixed effects only, Model (4) includes both firm and manager fixed effects, and Model (5) is a linear probability model (LPM) with both firm and manager fixed effects. We include year fixed effects in all specifications. We delete observations with missing values for RHS variables included in the benchmark specification, but include observations with missing values of tenure and age by using indicator variables for whether each is missing. Panel B uses the coefficient estimates in specification (5) of Panel A to decompose model R-squared in order to quantify the relative importance of each class of variable in determining the portion of bidder dummy explained. Refer to the Appendix for variable definitions. Heteroskedasticity robust $\mathrm{t}$-statistics clustered at the firm level are in parenthesis. ***,**, and * indicate significance at the 1,5 , and $10 \%$ levels,

respectively.

\section{Panel A:}

Dependent variable: Bidder dummy

\begin{tabular}{|c|c|c|c|c|c|}
\hline & $\begin{array}{c}\text { (1) } \\
\text { Probit } \\
\text { (no firm or } \\
\text { manager FE) }\end{array}$ & $\begin{array}{c}(2) \\
\text { Probit } \\
\text { Firm FE } \\
\text { (no manager FE) }\end{array}$ & $\begin{array}{c}\text { (3) } \\
\text { Probit } \\
\text { Manager FE } \\
\text { (no firm FE) }\end{array}$ & $\begin{array}{c}(4) \\
\text { Probit } \\
\text { Firm \& } \\
\text { Manager FE }\end{array}$ & $\begin{array}{c}\text { (5) } \\
\text { LPM } \\
\text { Firm \& } \\
\text { Manager FE }\end{array}$ \\
\hline \multirow[t]{2}{*}{ Abnormal return } & $0.024 *$ & $0.018^{*}$ & $0.018^{*}$ & $0.015^{*}$ & $0.003 * * *$ \\
\hline & 1.89 & 1.64 & 1.58 & 1.84 & 5.90 \\
\hline \multirow[t]{2}{*}{ Sales growth } & $0.511 * * *$ & $0.420 * * *$ & $0.251^{* *}$ & $0.275^{* * *}$ & $0.022 * * *$ \\
\hline & 17.87 & 9.54 & 2.87 & 2.70 & 3.27 \\
\hline \multirow[t]{2}{*}{$\begin{array}{l}\text { Noncash } \\
\text { working capital }\end{array}$} & $0.357 * * *$ & 0.105 & 0.001 & 0.007 & 0.020 \\
\hline & 2.48 & 1.22 & 0.00 & 0.00 & 0.94 \\
\hline \multirow[t]{2}{*}{ Leverage } & $-1.118 * * *$ & $-2.360 * * *$ & $-4.596 * * *$ & $-4.279 * * *$ & $-0.182 * * *$ \\
\hline & -18.07 & -17.85 & -15.41 & -13.00 & -10.79 \\
\hline \multirow[t]{2}{*}{ Market-to-book } & $0.067 * * *$ & $0.094 * * *$ & $0.227 * * *$ & $0.155 * * *$ & $0.024 * * *$ \\
\hline & 41.34 & 8.70 & 27.48 & 6.18 & 11.77 \\
\hline \multirow[t]{2}{*}{ Price-to-earnings } & $0.021 * * *$ & $-0.005 * * *$ & $-0.009 * * *$ & $-0.008 * * *$ & $-0.002 * *$ \\
\hline & 3.98 & -3.41 & -3.83 & -2.99 & -2.13 \\
\hline \multirow[t]{2}{*}{ Size } & $0.186^{* * * *}$ & $0.270 * * *$ & $0.220 * * *$ & $0.789 * * *$ & $0.067 * * *$ \\
\hline & 25.19 & 8.80 & 4.17 & 28.79 & 13.50 \\
\hline \multirow[t]{2}{*}{ Manager's delta } & $0.000 * * *$ & $0.000^{*}$ & 0.000 & 0.000 & $0.000 * * *$ \\
\hline & 3.10 & 1.68 & 0.35 & 0.68 & 2.61 \\
\hline \multirow[t]{2}{*}{ Age } & -0.001 & 0.001 & -0.011 & 0.005 & 0.003 \\
\hline & -1.08 & 0.44 & -0.97 & 0.56 & 0.59 \\
\hline \multirow[t]{2}{*}{ Tenure } & 0.001 & -0.000 & $0.045^{* * *}$ & 0.011 & 0.005 \\
\hline & 1.09 & -0.29 & 3.73 & 0.48 & 1.08 \\
\hline
\end{tabular}




\begin{tabular}{lccccc} 
Female & -0.034 & -0.041 & N/A & N/A & N/A \\
& -0.55 & -0.69 & & & \\
Mover & 0.009 & -0.058 & N/A & N/A & N/A \\
& 0.86 & -1.03 & & & \\
CEO & 0.011 & 0.020 & -0.020 & 0.009 & 0.001 \\
& 0.15 & 0.25 & -0.31 & 0.22 & 0.29 \\
Director & $-0.085^{* *}$ & -0.068 & $-0.279^{* *}$ & -0.097 & -0.019 \\
& -1.94 & -1.18 & -2.55 & -1.11 & -1.20 \\
Year FE & Yes & Yes & Yes & Yes & Yes \\
\hline Adjusted R $\mathrm{R}^{2}$ & 0.12 & 0.55 & 0.56 & 0.59 & 0.38 \\
$\mathrm{~N}$ & 64,428 & 64,428 & 64,428 & 64,428 & 64,428 \\
\hline
\end{tabular}

Panel B:

Relative Importance of Components in Determining Bidder

\begin{tabular}{lcc}
\hline & $\frac{\operatorname{cov}(\text { bidder,component })}{\operatorname{var}(\text { bidder })}$ & $\begin{array}{c}\% \text { of } \mathrm{R}^{2} \text { attributable } \\
\text { to the component }\end{array}$ \\
\hline $\begin{array}{l}\text { Observable Firm } \\
\begin{array}{l}\text { Obaracteristics } \\
\text { Characteristics }\end{array}\end{array}$ & 0.024 & $4.59 \%$ \\
Firm Fixed Effects & 0.003 & $0.57 \%$ \\
Manager Fixed Effects & 0.189 & $36.14 \%$ \\
Year Fixed Effects & 0.303 & $57.93 \%$ \\
Residual & 0.004 & $0.76 \%$ \\
\hline
\end{tabular}


Table 10

Observable and Unobservable Determinants of Target Dummy - Connectedness Sample with AKM Method

This table presents the results for specifications regressing bidder dummy on observable managerial and firm characteristics and on various combinations of fixed effects that proxy for time and for unobserved manager and firm attributes. The dependent variable is one if the firm is announced to be a target of a successful tender offer, merger proposal, or merger agreement in year $t$ and zero otherwise. The benchmark specification (model (1) in Panel A) is a probit regression, without firm or manager fixed effects (FE), which is based on the explanatory variables in Table 3, Column 1 in Comment and Schwert (1995) plus selected observable managerial attributes. Model (2) adds firm fixed effects only to the benchmark model, Model (3) adds manager fixed effects only, Model (4) includes both firm and manager fixed effects, and Model (5) is a linear probability model with both firm and manager fixed effects. We include year fixed effects in all specifications. We delete observations with missing values for RHS variables included in the benchmark specification, but include observations with missing values of tenure and age by using indicator variables for whether each is missing. Panel B uses the coefficient estimates in specification (5) of Panel A to decompose model R-squared in order to quantify the relative importance of each class of variable in determining the portion of target dummy explained. Refer to the Appendix for variable definitions. Heteroskedasticity robust t-statistics clustered at the firm level are in parenthesis. ${ }^{* *}, * *$, and $*$ indicate significance at the 1,5 , and $10 \%$ levels, respectively.

Panel A:

Dependent variable: Target dummy

\begin{tabular}{|c|c|c|c|c|c|}
\hline & $\begin{array}{c}\text { (1) } \\
\text { Probit } \\
\text { (no firm or } \\
\text { manager FE) }\end{array}$ & $\begin{array}{c}\text { (2) } \\
\text { Probit } \\
\text { Firm FE } \\
\text { (no manager FE) }\end{array}$ & $\begin{array}{c}(3) \\
\text { Probit } \\
\text { Manager FE } \\
\text { (no firm FE) }\end{array}$ & $\begin{array}{c}(4) \\
\text { Probit } \\
\text { Firm \& } \\
\text { Manager FE }\end{array}$ & $\begin{array}{c}\text { (5) } \\
\text { OLS } \\
\text { Firm \& } \\
\text { Manager FE }\end{array}$ \\
\hline Poison pill & $\begin{array}{c}0.131 * * * \\
2.81\end{array}$ & $\begin{array}{c}-0.461 * * \\
-2.38\end{array}$ & $\begin{array}{l}-0.207 \\
-0.75\end{array}$ & $\begin{array}{c}-0.641 * * \\
-2.42\end{array}$ & $\begin{array}{c}-0.010 \\
-1.39\end{array}$ \\
\hline Control share law & $\begin{array}{c}-0.277 * * * \\
-5.80\end{array}$ & $\begin{array}{c}0.073 \\
0.00\end{array}$ & $\begin{array}{c}-0.344 * * * \\
-3.76\end{array}$ & $\begin{array}{l}-0.112 \\
-0.05\end{array}$ & $\begin{array}{l}-0.002 \\
-0.13\end{array}$ \\
\hline $\begin{array}{l}\text { Business } \\
\text { combination law }\end{array}$ & $\begin{array}{l}-0.054 \\
-0.79\end{array}$ & $\begin{array}{c}0.319 \\
0.40\end{array}$ & $\begin{array}{c}1.087 \\
1.38\end{array}$ & $\begin{array}{l}-0.094 \\
-0.05\end{array}$ & $\begin{array}{c}0.005 \\
0.19\end{array}$ \\
\hline Abnormal return & $\begin{array}{c}0.381 * * \\
2.14\end{array}$ & $\begin{array}{l}0.322 * * * \\
2.60\end{array}$ & $\begin{array}{c}0.385^{* * * *} \\
2.99\end{array}$ & $\begin{array}{c}0.434 * * * \\
3.15\end{array}$ & $\begin{array}{c}0.040 * * \\
2.73\end{array}$ \\
\hline Sales growth & $\begin{array}{l}-0.000 \\
-0.00\end{array}$ & $\begin{array}{l}-0.381 \\
-1.10\end{array}$ & $\begin{array}{c}-0.599 * \\
-1.87\end{array}$ & $\begin{array}{l}-0.487 \\
-1.09\end{array}$ & $\begin{array}{c}-0.011 * * \\
-2.48\end{array}$ \\
\hline Liquidity & $\begin{array}{c}0.035^{* *} \\
3.11\end{array}$ & $\begin{array}{c}0.573 * * * \\
6.48\end{array}$ & $\begin{array}{c}0.670 * * * \\
5.51\end{array}$ & $\begin{array}{c}0.822 * * * \\
5.12\end{array}$ & $\begin{array}{c}0.051 * * * \\
3.87\end{array}$ \\
\hline Debt/equity & $\begin{array}{c}0.051 \\
0.48\end{array}$ & $\begin{array}{l}-0.431 \\
-0.86\end{array}$ & $\begin{array}{l}-0.874 \\
-1.14\end{array}$ & $\begin{array}{c}-1.461 \\
-1.18\end{array}$ & $\begin{array}{l}-0.000 \\
-0.04\end{array}$ \\
\hline Market-to-book & $\begin{array}{c}-0.044^{* *} \\
-2.53\end{array}$ & $\begin{array}{c}-0.591 * * * \\
-6.71\end{array}$ & $\begin{array}{c}-0.561 * * * \\
-4.70\end{array}$ & $\begin{array}{c}-0.596 * * * \\
-4.78\end{array}$ & $\begin{array}{c}-0.005 * * * \\
-4.65\end{array}$ \\
\hline Price/earnings & $\begin{array}{c}0.001 \\
0.82\end{array}$ & $\begin{array}{l}-0.015^{*} \\
-1.84\end{array}$ & $\begin{array}{l}-0.001 \\
-0.00\end{array}$ & $\begin{array}{l}-0.005 \\
-0.66\end{array}$ & $\begin{array}{l}-0.001 \\
-0.73\end{array}$ \\
\hline Size & $-0.107 * * *$ & -0.290 & $-0.441 * *$ & -0.071 & -0.001 \\
\hline
\end{tabular}




\begin{tabular}{lccccc} 
& -7.76 & -1.59 & -2.17 & -0.25 & -0.91 \\
Age & 0.001 & 0.004 & -0.004 & -0.015 & 0.000 \\
Tenure & 0.12 & 0.19 & -0.20 & -0.12 & 0.51 \\
& -0.006 & 0.012 & 0.071 & 0.024 & -0.000 \\
Female & -1.24 & 1.09 & 1.14 & 0.10 & -0.27 \\
& $0.181^{* * *}$ & $0.246^{*}$ & N/A & N/A & N/A \\
Mover & 3.17 & 1.80 & & & \\
& $0.155^{* * *}$ & -0.117 & N/A & N/A & N/A \\
CEO & 3.61 & -0.82 & & & \\
& 0.050 & 0.091 & -0.119 & -0.108 & 0.000 \\
Director & 0.31 & 0.40 & -0.28 & -0.39 & 0.12 \\
& -0.088 & -0.061 & 0.127 & -0.141 & -0.002 \\
Year FE & -1.29 & -0.38 & 0.24 & -0.15 & -0.36 \\
\hline Adjusted $\mathrm{R}^{2}$ & Yes & Yes & Yes & Yes & Yes \\
N & 0.08 & 0.57 & 0.63 & 0.63 & 0.29 \\
\hline & 48,365 & 48,365 & 48,365 & 48,365 & 48,365 \\
\hline
\end{tabular}

Panel B:

Relative Importance of Components in Determining Target

\begin{tabular}{lcc}
\hline & $\frac{\operatorname{cov}(\text { target, component })}{\operatorname{var}(\text { target })}$ & $\begin{array}{c}\% \text { of } \mathrm{R}^{2} \text { attributable } \\
\text { to the component }\end{array}$ \\
\hline $\begin{array}{l}\text { Observable Firm } \\
\text { Characteristics }\end{array}$ & 0.005 & $0.75 \%$ \\
$\begin{array}{l}\text { Observable Manager } \\
\text { Characteristics }\end{array}$ & 0.003 & $0.64 \%$ \\
Firm Fixed Effects & 0.165 & $32.67 \%$ \\
Manager Fixed Effects & 0.293 & $62.34 \%$ \\
Year Fixed Effects & 0.004 & $0.60 \%$ \\
Residual & 0.530 & \\
\hline
\end{tabular}


Table 11

Observable and Unobservable Determinants of Poison Pill - Connectedness Sample with AKM Method

This table presents the results for specifications regressing bidder dummy on observable managerial and firm characteristics and on various combinations of fixed effects that proxy for time and for unobserved manager and firm attributes. The dependent variable is one if the firm adopts poison pill in year $t$ and zero otherwise. The benchmark specification (model (1) in Panel A) is a probit regression, without firm or manager fixed effects (FE), which is based on the explanatory variables in Table 3, Column 4 in Comment and Schwert (1995) plus selected observable managerial attributes. Model (2) adds firm fixed effects only to the benchmark model, Model (3) adds manager fixed effects only, Model (4) includes both firm and manager fixed effects, and Model (5) is a linear probability model with both firm and manager fixed effects. We include year fixed effects in all specifications. We delete observations with missing values for RHS variables included in the benchmark specification, but include observations with missing values of tenure and age by using indicator variables for whether each is missing. Panel B uses the coefficient estimates in specification (5) of Panel A to decompose model R-squared in order to quantify the relative importance of each class of variable in determining the portion of poison pill explained. Refer to the Appendix for variable definitions. Heteroskedasticity robust $\mathrm{t}$-statistics clustered at the firm level are in parenthesis. ***,**, and * indicate significance at the 1,5 , and $10 \%$ levels,

respectively.

Panel A:

Dependent variable: Poison pill dummy

\begin{tabular}{|c|c|c|c|c|c|}
\hline & $\begin{array}{c}(1) \\
\text { Probit } \\
\text { (no firm or } \\
\text { manager FE) }\end{array}$ & $\begin{array}{c}\text { (2) } \\
\text { Probit } \\
\text { Firm FE } \\
\text { (no manager FE) }\end{array}$ & $\begin{array}{c}\text { (3) } \\
\text { Probit } \\
\text { Manager FE } \\
\text { (no firm FE) } \\
\end{array}$ & $\begin{array}{c}(4) \\
\text { Probit } \\
\text { Firm \& } \\
\text { Manager FE } \\
\end{array}$ & $\begin{array}{c}\text { (5) } \\
\text { OLS } \\
\text { Firm \& } \\
\text { Manager FE } \\
\end{array}$ \\
\hline Control share law & $\begin{array}{c}0.084 * * * \\
5.57\end{array}$ & $\begin{array}{c}-1.538 * * * \\
-7.75\end{array}$ & $\begin{array}{c}-0.598 * * * \\
-2.84\end{array}$ & $\begin{array}{c}-2.708 * * * \\
-5.36\end{array}$ & $\begin{array}{c}-0.148 * * * \\
-5.20\end{array}$ \\
\hline $\begin{array}{l}\text { Business } \\
\text { combination law }\end{array}$ & $\begin{array}{c}0.618 * * * \\
21.77\end{array}$ & $\begin{array}{c}1.481 * * * \\
7.84\end{array}$ & $\begin{array}{c}4.277 * * * \\
8.41\end{array}$ & $\begin{array}{c}5.731 * * * \\
4.08\end{array}$ & $\begin{array}{c}0.171^{* * * *} \\
7.78\end{array}$ \\
\hline Abnormal return & $\begin{array}{c}0.611 * * * \\
4.64\end{array}$ & $\begin{array}{l}0.624 * * * \\
2.48\end{array}$ & $\begin{array}{c}0.174 * * * \\
2.57\end{array}$ & $\begin{array}{c}0.071 \\
0.42\end{array}$ & $\begin{array}{l}-0.025 \\
-0.54\end{array}$ \\
\hline Sales growth & $\begin{array}{c}-0.194 * * * \\
-5.80\end{array}$ & $\begin{array}{l}-0.068 \\
-1.24\end{array}$ & $\begin{array}{l}-0.074 \\
-0.57\end{array}$ & $\begin{array}{c}-0.300 * * \\
-2.19\end{array}$ & $\begin{array}{c}-0.031^{* * *} \\
-2.94\end{array}$ \\
\hline Liquidity & $\begin{array}{l}-0.076 \\
-1.21\end{array}$ & $\begin{array}{c}-0.824 * * * \\
-3.95\end{array}$ & $\begin{array}{c}-0.698^{*} \\
-1.74\end{array}$ & $\begin{array}{c}-1.770 * * * \\
-2.97\end{array}$ & $\begin{array}{l}-0.071 \\
-0.92\end{array}$ \\
\hline Debt/equity & $\begin{array}{l}-0.000 \\
-0.07\end{array}$ & $\begin{array}{c}0.397 * * \\
2.20\end{array}$ & $\begin{array}{c}0.789 * * \\
2.51\end{array}$ & $\begin{array}{c}0.712^{*} \\
1.91\end{array}$ & $\begin{array}{c}0.045^{* *} \\
2.35\end{array}$ \\
\hline Market-to-book & $\begin{array}{c}-0.086 * * * \\
-20.74\end{array}$ & $\begin{array}{c}0.015 \\
0.67\end{array}$ & $\begin{array}{c}-0.236 * * * \\
-6.16\end{array}$ & $\begin{array}{c}0.022 \\
0.40\end{array}$ & $\begin{array}{c}-0.010^{*} \\
-1.71\end{array}$ \\
\hline Price/earnings & $\begin{array}{c}0.058^{* * *} \\
30.57\end{array}$ & $\begin{array}{l}-0.000 \\
-0.37\end{array}$ & $\begin{array}{c}-0.007 * * * \\
-2.92\end{array}$ & $\begin{array}{c}-0.008^{* * *} \\
-3.43\end{array}$ & $\begin{array}{c}-0.005^{* * *} \\
-3.23\end{array}$ \\
\hline Size & $\begin{array}{c}0.055^{* * * *} \\
31.14\end{array}$ & $\begin{array}{c}-0.281 * * * \\
-6.79\end{array}$ & $\begin{array}{c}-0.724 * * * \\
-7.60\end{array}$ & $\begin{array}{c}-0.756^{* * * *} \\
-5.88\end{array}$ & $\begin{array}{c}-0.022 * * * \\
-4.02\end{array}$ \\
\hline Age & $\begin{array}{c}0.005^{* * *} \\
3.76\end{array}$ & $\begin{array}{c}0.005 \\
0.84\end{array}$ & $\begin{array}{c}0.100 \\
1.55\end{array}$ & $\begin{array}{l}-0.007 \\
-0.42\end{array}$ & $\begin{array}{c}0.004^{*} \\
1.67\end{array}$ \\
\hline
\end{tabular}




\begin{tabular}{lccccc} 
Tenure & $0.005^{* * *}$ & $0.018^{* * *}$ & -0.018 & $0.124 * * *$ & $0.008^{* *}$ \\
& 3.54 & 4.55 & -0.96 & 3.27 & 2.33 \\
Female & & & & N/A \\
& $-0.087^{* *}$ & $-0.145^{* *}$ & N/A & & \\
Mover & -2.48 & -2.20 & & N/A & N/A \\
& $0.128^{* * *}$ & 0.075 & N/A & & \\
CEO & 6.24 & 1.25 & & $-0.020^{* *}$ \\
& $0.120^{* * *}$ & -0.134 & -0.218 & $-0.442^{* *}$ & -2.48 \\
Director & 4.76 & -1.27 & -1.33 & -2.91 & -0.012 \\
& $-0.085 * * *$ & 0.055 & $0.294 *$ & -0.192 & -1.16 \\
Year FE & -3.71 & 0.82 & 2.04 & -0.87 & Yes \\
\hline Adjusted $\mathrm{R}^{2}$ & Yes & Yes & Yes & Yes & 0.83 \\
$\mathrm{~N}$ & 0.07 & 0.88 & 0.89 & 0.91 & 48,365 \\
\hline
\end{tabular}

\section{Panel B:}

Relative Importance of Components in Determining Poison Pill

\begin{tabular}{lcc}
\hline & $\frac{\operatorname{cov}(\text { PoisonPill,component })}{\operatorname{var}(\text { PoisonPill })}$ & $\begin{array}{c}\% \text { of } \mathrm{R}^{2} \text { attributable } \\
\text { to the component }\end{array}$ \\
\hline $\begin{array}{l}\text { Observable Firm } \\
\text { Characteristics }\end{array}$ & 0.015 & $1.70 \%$ \\
$\begin{array}{l}\text { Observable Manager } \\
\text { Characteristics }\end{array}$ & 0.002 & $0.23 \%$ \\
Firm Fixed Effects & 0.500 & $57.24 \%$ \\
Manager Fixed Effects & 0.356 & $40.60 \%$ \\
Year Fixed Effects & 0.002 & $0.23 \%$ \\
Residual & 0.123 & \\
\hline
\end{tabular}


Table 12

Observable and Unobservable Determinants of Book Leverage - Connectedness Sample with AKM Method

This table presents the results for specifications regressing corporate book leverage on observable managerial and firm characteristics and on various combinations of fixed effects that proxy for time and for unobserved manager and firm attributes. The benchmark specification (model (1) in Panel A) is a pooled OLS regression, without firm or manager fixed effects (FE), which is based on the explanatory variables in Table II, Panel A, Column 3 in Lemmon, Roberts, and Zender (2008) plus selected observable managerial attributes. Model (2) adds firm fixed effects only to the benchmark model, Model (3) adds manager fixed effects only, and Model (4) includes both firm and manager fixed effects. We include year fixed effects in all specifications. We delete observations with missing values for RHS variables included in the benchmark specification, but include observations with missing values of tenure and age by using indicator variables for whether each is missing. Panel B uses the coefficient estimates in specification (4) of Panel A to decompose model R-squared in order to quantify the relative importance of each class of variable in determining the portion of book leverage explained. Refer to the Appendix for variable definitions. Heteroskedasticity robust t-statistics clustered at the firm level are in parenthesis. $* * *, * *$, and * indicate significance at the 1,5 , and $10 \%$ levels, respectively.

Panel A:

Dependent variable: Book Leverage

\begin{tabular}{|c|c|c|c|c|}
\hline & $\begin{array}{c}\text { (1) } \\
\text { Pooled OLS } \\
\text { (no firm or manager FE) }\end{array}$ & $\begin{array}{c}(2) \\
\text { Firm FE } \\
\text { (no manager FE) }\end{array}$ & $\begin{array}{c}(3) \\
\text { Manager FE } \\
\text { (no firm FE) }\end{array}$ & $\begin{array}{c}\text { (4) } \\
\text { Firm \& } \\
\text { Manager FE }\end{array}$ \\
\hline Initial book lev. & $\begin{array}{c}0.266^{* * *} \\
65.76\end{array}$ & N/A & $\begin{array}{c}0.233 * * * \\
21.60\end{array}$ & N/A \\
\hline Log(Sales) & $\begin{array}{l}0.003 * * * \\
5.48\end{array}$ & $\begin{array}{c}-0.004 * * \\
-2.33\end{array}$ & $\begin{array}{c}0.000 \\
0.27\end{array}$ & $\begin{array}{c}0.000 \\
0.30\end{array}$ \\
\hline Market-to-book & $\begin{array}{l}-0.009 * * * \\
-20.22\end{array}$ & $\begin{array}{l}-0.007 * * * \\
-12.57\end{array}$ & $\begin{array}{l}-0.007 * * * \\
-11.05\end{array}$ & $\begin{array}{l}-0.007 * * * \\
-11.03\end{array}$ \\
\hline Profitability & $\begin{array}{c}-0.128 * * * \\
-18.46\end{array}$ & $\begin{array}{l}-0.143 * * * \\
-19.57\end{array}$ & $\begin{array}{l}-0.105^{* * *} \\
-13.29\end{array}$ & $\begin{array}{l}-0.082 * * * \\
-10.02\end{array}$ \\
\hline Tangibility & $\begin{array}{c}0.090 * * * \\
23.31\end{array}$ & $\begin{array}{c}0.084 * * * \\
10.51\end{array}$ & $\begin{array}{l}0.110 * * * \\
12.74\end{array}$ & $\begin{array}{l}0.108 * * * \\
10.75\end{array}$ \\
\hline Industry median lev. & $\begin{array}{l}0.320 * * * \\
38.47\end{array}$ & $\begin{array}{l}0.302 * * * \\
16.19\end{array}$ & $\begin{array}{l}0.245 * * * \\
14.57\end{array}$ & $\begin{array}{l}0.199 * * * \\
\quad 9.16\end{array}$ \\
\hline Dividend payer & $\begin{array}{l}0.020 * * * \\
12.41\end{array}$ & $\begin{array}{l}0.012 * * * \\
5.20\end{array}$ & $\begin{array}{c}0.010 \\
0.73\end{array}$ & $\begin{array}{c}0.005 \\
1.27\end{array}$ \\
\hline Cash flow vol. & $\begin{array}{l}-0.109 * * * \\
-7.44\end{array}$ & $\begin{array}{c}0.008 \\
0.25\end{array}$ & $\begin{array}{l}-0.049 * * \\
-2.08\end{array}$ & $\begin{array}{l}-0.040 * * \\
-2.01\end{array}$ \\
\hline Age & $\begin{array}{c}0.000 \\
0.56\end{array}$ & $\begin{array}{c}-0.000 \\
-0.17\end{array}$ & $\begin{array}{l}-0.000 \\
-1.08\end{array}$ & $\begin{array}{c}0.000 \\
0.01\end{array}$ \\
\hline Tenure & $\begin{array}{c}-0.001 * * * \\
-6.04\end{array}$ & $\begin{array}{c}-0.000 * * \\
-2.48\end{array}$ & $\begin{array}{c}0.001 * * * \\
2.66\end{array}$ & $\begin{array}{c}0.000 \\
0.27\end{array}$ \\
\hline Female & $\begin{array}{c}0.001 \\
0.37\end{array}$ & $\begin{array}{c}-0.000 \\
-0.30\end{array}$ & N/A & N/A \\
\hline Mover & $-0.004 *$ & 0.001 & N/A & N/A \\
\hline
\end{tabular}




\begin{tabular}{lcccc} 
& -1.64 & 0.55 & & \\
CEO & $0.009 * * *$ & 0.003 & 0.003 & $0.004^{*}$ \\
& 3.01 & 1.48 & 1.40 & 1.78 \\
Director & & & & $0.006^{*}$ \\
& -0.003 & 0.002 & 1.79 & $0.006^{* *}$ \\
& -0.74 & 0.85 & Yes & Yes \\
Year Fixed Effects & Yes & Yes & 0.71 & 0.74 \\
Adjusted R & 0.23 & 0.67 & 56,590 & 56,590 \\
$\mathrm{~N}$ & 56,590 & 56,590 & & \\
\hline
\end{tabular}

Panel B:

Relative Importance of Components in Determining Book Leverage

\begin{tabular}{lcc}
\hline & $\frac{\operatorname{cov}(\text { BookLeverage, component })}{\operatorname{var}(\text { BookLeverage })}$ & $\begin{array}{c}\% \text { of } \mathrm{R}^{2} \text { attributable } \\
\text { to the component }\end{array}$ \\
\hline $\begin{array}{l}\text { Observable Firm } \\
\begin{array}{l}\text { Characteristics } \\
\text { Observable Manager }\end{array}\end{array}$ & 0.088 & $10.76 \%$ \\
Characteristics & 0.006 & $0.73 \%$ \\
Firm Fixed Effects & 0.511 & $62.47 \%$ \\
Manager Fixed Effects & 0.209 & $25.55 \%$ \\
Year Fixed Effects & 0.004 & $0.49 \%$ \\
Residual & 0.182 & \\
\hline
\end{tabular}


Table 13

Observable and Unobservable Determinants of Market Leverage - Connectedness Sample with AKM Method

This table presents the results for specifications regressing corporate market leverage on observable managerial and firm characteristics and on various combinations of fixed effects that proxy for time and for unobserved manager and firm attributes. The benchmark specification (model (1) in Panel A) is a pooled OLS regression, without firm or manager fixed effects (FE), which is based on the explanatory variables in Table II, Panel A, Column 6 in Lemmon, Roberts, and Zender (2008) plus selected observable managerial attributes. Model (2) adds firm fixed effects only to the benchmark model, Model (3) adds manager fixed effects only, and Model (4) includes both firm and manager fixed effects. We include year fixed effects in all specifications. We delete observations with missing values for RHS variables included in the benchmark specification, but include observations with missing values of tenure and age by using indicator variables for whether each is missing. Panel B uses the coefficient estimates in specification (4) of Panel A to decompose model R-squared in order to quantify the relative importance of each class of variable in determining the portion of market leverage explained. Refer to the Appendix for variable definitions. Heteroskedasticity robust tstatistics clustered at the firm level are in parenthesis. $* * *, * *$, and $*$ indicate significance at the 1,5 , and $10 \%$ levels, respectively.

Panel A:

Dependent variable: Market Leverage

\begin{tabular}{|c|c|c|c|c|}
\hline & $\begin{array}{c}\text { (1) } \\
\text { Pooled OLS } \\
\text { (no firm or manager FE) }\end{array}$ & $\begin{array}{c}(2) \\
\text { Firm FE } \\
\text { (no manager FE) }\end{array}$ & $\begin{array}{c}(3) \\
\text { Manager FE } \\
\text { (no firm FE) }\end{array}$ & $\begin{array}{c}\text { (4) } \\
\text { Firm \& } \\
\text { Manager FE }\end{array}$ \\
\hline Initial book lev. & $\begin{array}{c}0.265 * * * \\
67.24\end{array}$ & N/A & $\begin{array}{c}0.250 * * * \\
23.30\end{array}$ & N/A \\
\hline Log(Sales) & $\begin{array}{l}0.012 * * * \\
20.77\end{array}$ & $\begin{array}{l}0.018 * * * \\
16.45\end{array}$ & $\begin{array}{l}0.014 * * * \\
11.35\end{array}$ & $\begin{array}{l}0.024 * * * \\
15.33\end{array}$ \\
\hline Market-to-book & $\begin{array}{c}-0.036 * * * \\
-59.86\end{array}$ & $\begin{array}{l}-0.016 * * * \\
-29.71\end{array}$ & $\begin{array}{c}-0.016 * * * \\
-26.94\end{array}$ & $\begin{array}{c}-0.015 * * * \\
-24.03\end{array}$ \\
\hline Profitability & $\begin{array}{l}-0.277 * * * \\
-39.69\end{array}$ & $\begin{array}{l}-0.255^{* * * *} \\
-35.98\end{array}$ & $\begin{array}{l}-0.201 * * * \\
-24.63\end{array}$ & $\begin{array}{l}-0.187 * * * \\
-22.24\end{array}$ \\
\hline Tangibility & $\begin{array}{c}0.063 * * * \\
16.43\end{array}$ & $\begin{array}{c}0.027 \\
1.40\end{array}$ & $\begin{array}{l}0.058 * * * \\
6.64\end{array}$ & $\begin{array}{l}0.034 * * * \\
2.89\end{array}$ \\
\hline Industry median lev. & $\begin{array}{l}0.390 * * * \\
\quad 47.65\end{array}$ & $\begin{array}{l}0.509 * * * \\
28.65\end{array}$ & $\begin{array}{l}0.429 * * * \\
25.88\end{array}$ & $\begin{array}{l}0.408 * * * \\
18.95\end{array}$ \\
\hline Dividend payer & $\begin{array}{c}0.001 \\
0.25\end{array}$ & $\begin{array}{l}0.009 * * * \\
4.79\end{array}$ & $\begin{array}{c}0.001 \\
0.57\end{array}$ & $\begin{array}{l}0.009 * * * \\
\quad 4.00\end{array}$ \\
\hline Cash flow vol. & $\begin{array}{l}-0.155^{* * * *} \\
-10.60\end{array}$ & $\begin{array}{l}-0.108 * * * \\
-6.65\end{array}$ & $\begin{array}{c}-0.080 * * * \\
-4.15\end{array}$ & $\begin{array}{l}-0.083 * * * \\
-4.54\end{array}$ \\
\hline Age & $\begin{array}{l}-0.000 * * \\
-2.56\end{array}$ & $\begin{array}{l}-0.000 \\
-0.58\end{array}$ & $\begin{array}{l}-0.001 \\
-0.84\end{array}$ & $\begin{array}{c}-0.001 \\
-1.61\end{array}$ \\
\hline Tenure & $\begin{array}{c}-0.001 * * * \\
-11.12\end{array}$ & $\begin{array}{c}-0.000 * * * \\
-3.24\end{array}$ & $\begin{array}{c}-0.000 \\
-1.77\end{array}$ & $\begin{array}{c}0.000 \\
0.60\end{array}$ \\
\hline Female & $\begin{array}{c}0.003 \\
0.74\end{array}$ & $\begin{array}{c}-0.000 \\
-0.08\end{array}$ & N/A & N/A \\
\hline
\end{tabular}




\begin{tabular}{|c|c|c|c|c|}
\hline Mover & $\begin{array}{c}-0.010 * * * \\
-4.26\end{array}$ & $\begin{array}{l}-0.005 \\
-1.65\end{array}$ & N/A & N/A \\
\hline CEO & $\begin{array}{c}0.012 * * * \\
4.77\end{array}$ & $\begin{array}{c}0.003 * \\
1.70\end{array}$ & $\begin{array}{c}0.004 * * \\
2.02\end{array}$ & $\begin{array}{c}0.005 \\
1.08\end{array}$ \\
\hline Director & $\begin{array}{c}-0.006 * * \\
-2.15\end{array}$ & $\begin{array}{l}-0.000 \\
-0.48\end{array}$ & $\begin{array}{c}0.009 * * * \\
3.19\end{array}$ & $\begin{array}{c}0.000 \\
0.18\end{array}$ \\
\hline Year Fixed Effects & Yes & Yes & Yes & Yes \\
\hline Adjusted $\mathrm{R}^{2}$ & 0.39 & 0.74 & 0.77 & 0.79 \\
\hline $\mathrm{N}$ & 73,629 & 73,629 & 73,629 & 73,629 \\
\hline
\end{tabular}

Panel B:

Relative Importance of Components in Determining Market Leverage

\begin{tabular}{lcc}
\hline & $\frac{\operatorname{cov}(\text { MarketLeverage, component })}{\operatorname{var}(\text { MarketLeverage })}$ & $\begin{array}{c}\% \text { of } \mathrm{R}^{2} \text { attributable } \\
\text { to the component }\end{array}$ \\
\hline $\begin{array}{l}\text { Observable Firm } \\
\text { Characteristics }\end{array}$ & 0.191 & $22.50 \%$ \\
Observable Manager & 0.001 & $0.13 \%$ \\
Firm Fixed Effects & 0.438 & $51.57 \%$ \\
Manager Fixed Effects & 0.209 & $24.62 \%$ \\
Year Fixed Effects & 0.010 & $1.17 \%$ \\
Residual & 0.151 & \\
\hline
\end{tabular}


Table 14

Observable and Unobservable Determinants of Cash Holdings - Connectedness Sample with AKM Method

This table presents the results for specifications regressing corporate cash holdings on observable managerial and firm characteristics and on various combinations of fixed effects that proxy for time and for unobserved manager and firm attributes. The benchmark specification (model (1) in Panel A) is a pooled OLS regression, without firm or manager fixed effects (FE), which is based on the explanatory variables in Table 3, Column 1 in Harford, Mansi, and Maxwell (2008) plus selected observable managerial attributes. Model (2) adds firm fixed effects only to the benchmark model, Model (3) adds manager fixed effects only, and Model (4) includes both firm and manager fixed effects. We include year fixed effects in all specifications. We delete observations with missing values for RHS variables included in the benchmark specification, but include observations with missing values of tenure and age by using indicator variables for whether each is missing. Panel B uses the coefficient estimates in specification (4) of Panel A to decompose model Rsquared in order to quantify the relative importance of each class of variable in determining the portion of cash holdings explained. Refer to the Appendix for variable definitions. Heteroskedasticity robust t-statistics clustered at the firm level are in parenthesis. $* * *, * *$, and $*$ indicate significance at the 1,5 , and $10 \%$ levels, respectively.

Panel A:

Dependent variable: Natural logarithm of the ration of cash holdings to sales

\begin{tabular}{|c|c|c|c|c|}
\hline & $\begin{array}{c}\text { (1) } \\
\text { Pooled OLS } \\
\text { (no firm or manager FE) }\end{array}$ & $\begin{array}{c}(2) \\
\text { Firm FE } \\
\text { (no manager FE) }\end{array}$ & $\begin{array}{c}(3) \\
\text { Manager FE } \\
\text { (no firm FE) }\end{array}$ & $\begin{array}{c}\text { (4) } \\
\text { Firm \& Manager } \\
\text { FE }\end{array}$ \\
\hline \multirow[t]{2}{*}{ Gindex } & $-0.030 * * *$ & $-0.007 * *$ & $-0.013 * * *$ & -0.003 \\
\hline & -12.48 & -2.00 & -3.78 & -0.75 \\
\hline \multirow[t]{2}{*}{ Inside Ownership } & $2.068 * * *$ & $0.461 * * *$ & $0.862 * * *$ & $0.595 * * *$ \\
\hline & 9.84 & 3.34 & 5.84 & 3.71 \\
\hline \multirow[t]{2}{*}{ Pay sensitivity } & $0.255^{* * * *}$ & $0.184 * * *$ & $0.185^{* *}$ & $0.152 * *$ \\
\hline & 3.35 & 3.64 & 2.24 & 2.18 \\
\hline \multicolumn{5}{|l|}{ Institutional } \\
\hline \multirow[t]{2}{*}{ ownership } & $0.115^{* *}$ & 0.005 & $0.130 * *$ & $0.084 *$ \\
\hline & 2.10 & 0.25 & 2.28 & 1.86 \\
\hline \multirow[t]{2}{*}{ Size } & $-0.085^{*}$ & $-0.110 * * *$ & $-0.125 * * *$ & $-0.151 * * *$ \\
\hline & -1.85 & -11.24 & 11.25 & -11.31 \\
\hline \multirow[t]{2}{*}{ Leverage } & $-1.558 * * *$ & $-0.262 * * *$ & $-0.392 * * *$ & $-0.196 * * *$ \\
\hline & -38.79 & -7.52 & -8.48 & -4.45 \\
\hline \multirow[t]{2}{*}{ Market-to-book } & $0.080 * * *$ & $0.020 * * *$ & $0.011^{*}$ & $0.006^{*}$ \\
\hline & 15.62 & 4.48 & 1.85 & 1.75 \\
\hline \multirow[t]{2}{*}{ Cash flow } & $0.657 * * *$ & $0.184 * * *$ & $0.347 * * *$ & $0.318 * * *$ \\
\hline & 9.68 & 2.74 & 5.37 & 4.57 \\
\hline \multirow[t]{2}{*}{ Working capital } & $-1.491 * * *$ & $-0.637 * * *$ & $-0.681 * * *$ & $-0.482 * * *$ \\
\hline & -36.70 & -12.86 & -9.15 & -4.88 \\
\hline \multirow[t]{2}{*}{ CF volatility } & $4.264 * * *$ & $0.884 * * *$ & $0.797 * * *$ & $0.278^{*}$ \\
\hline & 28.51 & 6.20 & 4.68 & 1.64 \\
\hline \multirow[t]{2}{*}{$\mathrm{R} \& \mathrm{D}$} & $5.945 * * *$ & $-0.968 * * *$ & $-0.528 * * *$ & $-0.741 * * *$ \\
\hline & 55.76 & -7.84 & -4.41 & -6.93 \\
\hline
\end{tabular}




\begin{tabular}{|c|c|c|c|c|}
\hline CapEx & $\begin{array}{c}-3.622 * * * \\
-26.08\end{array}$ & $\begin{array}{c}-1.323^{* * *} \\
-11.56\end{array}$ & $\begin{array}{c}-1.306^{* * *} \\
-10.16\end{array}$ & $\begin{array}{c}-1.180^{* * * *} \\
9.32\end{array}$ \\
\hline Acquisition & $\begin{array}{c}-2.311 * * * \\
-22.85\end{array}$ & $\begin{array}{c}-1.416 * * * \\
-21.38\end{array}$ & $\begin{array}{c}-1.180 * * * \\
-16.28\end{array}$ & $\begin{array}{c}-1.088^{* * *} \\
-16.11\end{array}$ \\
\hline Dividend indicator & $\begin{array}{c}-0.465^{* * *} \\
-32.10\end{array}$ & $\begin{array}{c}-0.072 * * * \\
-3.43\end{array}$ & $\begin{array}{c}-0.091 * * * * \\
-4.82\end{array}$ & $\begin{array}{c}-0.083 * * * \\
-4.12\end{array}$ \\
\hline Bond indicator & $\begin{array}{c}-0.144 * * * \\
-9.74\end{array}$ & $\begin{array}{c}-0.049^{*} \\
-1.78\end{array}$ & $\begin{array}{c}0.009 \\
0.35\end{array}$ & $\begin{array}{c}0.038^{* *} \\
2.25\end{array}$ \\
\hline Age & $\begin{array}{c}0.000 \\
0.87\end{array}$ & $\begin{array}{c}0.000 \\
0.51\end{array}$ & $\begin{array}{c}-0.006^{*} \\
-1.79\end{array}$ & $\begin{array}{c}-0.010 * * \\
-2.33\end{array}$ \\
\hline Tenure & $\begin{array}{c}-0.008 * * * \\
-7.14\end{array}$ & $\begin{array}{c}-0.006 * * * \\
-4.74\end{array}$ & $\begin{array}{c}-0.015^{* * * *} \\
-6.10\end{array}$ & $\begin{array}{c}-0.026^{* * * *} \\
-7.40\end{array}$ \\
\hline Female & $\begin{array}{c}-0.051^{*} \\
-1.69\end{array}$ & $\begin{array}{l}-0.002 \\
-0.34\end{array}$ & N/A & N/A \\
\hline Mover & $\begin{array}{c}-0.026^{*} \\
-1.95\end{array}$ & $\begin{array}{l}-0.011 \\
-0.99\end{array}$ & N/A & N/A \\
\hline Director & $\begin{array}{c}-0.050 * * * \\
-2.84\end{array}$ & $\begin{array}{c}-0.027 * * \\
-2.35\end{array}$ & $\begin{array}{l}-0.028 \\
-1.23\end{array}$ & $\begin{array}{l}-0.028 \\
-1.27\end{array}$ \\
\hline Year Fixed Effects & Yes & Yes & Yes & Yes \\
\hline Adjusted $\mathrm{R}^{2}$ & 0.41 & 0.80 & 0.80 & 0.82 \\
\hline $\mathrm{N}$ & 48,215 & 48,215 & 48,215 & 48,215 \\
\hline
\end{tabular}

Panel B:

Relative Importance of Components in Determining Cash Holdings

\begin{tabular}{lcc}
\hline & $\frac{\operatorname{cov}(\text { CashHoldings, component })}{\operatorname{var}(\text { CashHoldings })}$ & $\begin{array}{c}\% \text { of } \mathrm{R}^{2} \text { attributable } \\
\text { to the component }\end{array}$ \\
\hline $\begin{array}{l}\text { Observable Firm } \\
\text { Characteristics }\end{array}$ & 0.148 & $17.03 \%$ \\
$\begin{array}{l}\text { Observable Manager } \\
\text { Characteristics }\end{array}$ & 0.007 & $0.80 \%$ \\
Firm Fixed Effects & 0.443 & $50.97 \%$ \\
Manager Fixed Effects & 0.250 & $28.77 \%$ \\
Year Fixed Effects & 0.021 & $2.42 \%$ \\
Residual & 0.131 & \\
\hline
\end{tabular}


Table 15

Observable and Unobservable Determinants of Dividend Payout - Connectedness Sample with AKM Method

This table presents the results for specifications regressing corporate decision to pay dividends (a dummy variable) on observable managerial and firm characteristics and on various combinations of fixed effects that proxy for time and for unobserved manager and firm attributes. The benchmark specification (model (1) in Panel A) is a pooled OLS regression, without firm or manager fixed effects (FE), which is based on the explanatory variables in Table 3, Column 1 in DeAngelo, DeAngelo, Stulz (2006) plus selected observable managerial attributes. Model (2) adds firm fixed effects only to the benchmark model, Model (3) adds manager fixed effects only, and Model (4) includes both firm and manager fixed effects, and Model (5) is a linear probability model with both firm and manager fixed effects. We include year fixed effects in all specifications. We delete observations with missing values for RHS variables included in the benchmark specification, but include observations with missing values of tenure and age by using indicator variables for whether each is missing. Panel B uses the coefficient estimates in specification (5) of Panel A to decompose model R-squared in order to quantify the relative importance of each class of variable in determining the portion of dividend payout explained. Refer to the Appendix for variable definitions. Heteroskedasticity robust $\mathrm{t}-$ statistics clustered at the firm level are in parenthesis. $* * *, * *$, and $*$ indicate significance at the 1,5 , and $10 \%$ levels, respectively.

Panel A:

Dependent variable: Dividend Payout

\begin{tabular}{|c|c|c|c|c|c|}
\hline & $\begin{array}{c}\text { (1) } \\
\text { Logistic } \\
\text { (no firm or } \\
\text { manager FE) }\end{array}$ & $\begin{array}{c}(2) \\
\text { Logistic } \\
\text { Firm FE } \\
\text { (no manager FE) }\end{array}$ & $\begin{array}{c}(3) \\
\text { Logistic } \\
\text { Manager FE } \\
\text { (no firm FE) }\end{array}$ & $\begin{array}{c}(4) \\
\text { Logistic } \\
\text { Firm \& } \\
\text { Manager FE }\end{array}$ & $\begin{array}{c}(5) \\
\text { OLS } \\
\text { Firm \& } \\
\text { Manager FE }\end{array}$ \\
\hline \multirow[t]{2}{*}{$\mathrm{RE} / \mathrm{TE}$} & $1.685 * * *$ & -0.025 & 0.008 & -0.035 & -0.054 \\
\hline & 6.76 & -0.78 & 0.07 & -0.87 & -0.38 \\
\hline \multirow[t]{2}{*}{ TE/TA } & $-1.284 * * *$ & $4.819 * * *$ & 1.408 & $6.715 * * *$ & $0.254 * * *$ \\
\hline & -24.89 & 3.54 & 0.97 & 3.21 & 3.90 \\
\hline \multirow[t]{2}{*}{ ROA } & $4.732 * * *$ & $1.941 * * *$ & $1.496 *$ & $2.233 * *$ & $0.081 * * *$ \\
\hline & 21.15 & 2.90 & 1.84 & 2.28 & 2.77 \\
\hline \multirow[t]{2}{*}{ Sales growth } & $-1.258 * * *$ & $-0.310 *$ & $-1.194 * * *$ & $-0.855 * * *$ & $-0.030 * * *$ \\
\hline & -48.71 & -1.94 & -4.587 & -3.17 & -3.55 \\
\hline \multirow[t]{2}{*}{ MTB } & $-0.084 * * *$ & $0.108 * *$ & $0.283 * * *$ & $0.254 * * *$ & $0.005 * * *$ \\
\hline & -4.48 & 2.10 & 4.51 & 3.97 & 2.99 \\
\hline \multirow[t]{2}{*}{ Log( assets) } & $0.463 * * *$ & $1.173 * * *$ & $1.320 * * *$ & $0.924 * * *$ & $0.040 * * *$ \\
\hline & 80.50 & 10.34 & 12.01 & 4.99 & 5.95 \\
\hline \multirow[t]{2}{*}{ Age } & $0.027 * * *$ & 0.007 & -0.011 & -0.105 & 0.000 \\
\hline & 10.84 & 0.89 & -0.14 & -1.05 & 0.10 \\
\hline \multirow[t]{2}{*}{ Tenure } & $0.021 * * *$ & $0.125 * *$ & $0.190 * * *$ & $0.212 * * *$ & $0.009 * * *$ \\
\hline & 5.33 & 2.31 & 4.78 & 3.97 & 3.18 \\
\hline \multirow[t]{2}{*}{ Female } & $-0.134 * *$ & $-0.483 * * *$ & N/A & N/A & N/A \\
\hline & -2.08 & -3.17 & & & \\
\hline \multirow[t]{2}{*}{ Mover } & -0.038 & -0.274 & N/A & N/A & N/A \\
\hline & -0.76 & -1.28 & & & \\
\hline CEO & 0.062 & 0.089 & -0.384 & -0.482 & -0.002 \\
\hline
\end{tabular}




\begin{tabular}{lccccc} 
& 0.33 & 0.14 & -1.04 & -1.09 & -0.57 \\
Director & 0.092 & -0.025 & -0.177 & -0.375 & $-0.024^{* * *}$ \\
& 1.21 & -0.10 & -0.94 & -1.25 & -3.42 \\
Year FE & Yes & Yes & Yes & Yes & Yes \\
\hline Adjusted R & 0.34 & 0.93 & 0.92 & 0.94 & 0.87 \\
$\mathrm{~N}$ & 31,980 & 31,980 & 31,980 & 31,980 & 31,980 \\
\hline
\end{tabular}

\section{Panel B:}

Relative Importance of Components in Determining Dividend Payout

\begin{tabular}{lcc}
\hline & $\frac{\operatorname{cov}(\text { Dividend,component })}{\operatorname{var}(\text { Dividend })}$ & $\begin{array}{c}\% \text { of } \mathrm{R}^{2} \text { attributable } \\
\text { to the component }\end{array}$ \\
\hline $\begin{array}{l}\text { Observable Firm } \\
\begin{array}{l}\text { Observabteristics } \\
\text { Characteristics }\end{array}\end{array}$ & 0.031 & $3.41 \%$ \\
Firm Fixed Effects & 0.002 & $0.22 \%$ \\
Manager Fixed Effects & 0.622 & $68.58 \%$ \\
Year Fixed Effects & 0.246 & $27.12 \%$ \\
Residual & 0.006 & $0.67 \%$ \\
\hline
\end{tabular}


Table 16

Observable and Unobservable Determinants of CAPEX - Connectedness Sample with AKM Method

This table presents the results for specifications regressing corporate capital expenditure on observable managerial and firm characteristics and on various combinations of fixed effects that proxy for time and for unobserved manager and firm attributes. The benchmark specification (model (1) in Panel A) is a pooled OLS regression, without firm or manager fixed effects (FE), which is based on the explanatory variables in Table 3, Panel B, Column 1 in Coles, Daniel, and Naveen (2006) plus selected observable managerial attributes. Model (2) adds firm fixed effects only to the benchmark model, Model (3) adds manager fixed effects only, and Model (4) includes both firm and manager fixed effects. We include year fixed effects in all specifications. We delete observations with missing values for RHS variables included in the benchmark specification, but include observations with missing values of tenure and age by using indicator variables for whether each is missing. Panel B uses the coefficient estimates in specification (4) of Panel A to decompose model R-squared in order to quantify the relative importance of each class of variable in determining the portion of CAPEX explained. Refer to the Appendix for variable definitions. Heteroskedasticity robust t-statistics clustered at the firm level are in parenthesis. $* * *, * *$, and $*$ indicate significance at the 1,5 , and $10 \%$ levels, respectively.

\section{Panel A:}

Dependent variable: CAPEX

\begin{tabular}{|c|c|c|c|c|}
\hline & $\begin{array}{c}\text { (1) } \\
\text { Pooled OLS } \\
\text { (no firm or manager FE) }\end{array}$ & $\begin{array}{c}\text { (2) } \\
\text { Firm FE } \\
\text { (no manager FE) }\end{array}$ & $\begin{array}{c}(3) \\
\text { Manager FE } \\
\text { (no firm FE) }\end{array}$ & $\begin{array}{c}\text { (4) } \\
\text { Firm \& Manager } \\
\text { FE }\end{array}$ \\
\hline Vega & $\begin{array}{c}-0.008 * * * \\
-3.76\end{array}$ & $\begin{array}{c}0.006 * * \\
2.24\end{array}$ & $\begin{array}{c}-0.005^{*} \\
-1.78\end{array}$ & $\begin{array}{l}-0.002 \\
-0.85\end{array}$ \\
\hline Delta & $\begin{array}{l}0.003 * * * \\
\quad 4.60\end{array}$ & $\begin{array}{l}0.002 * * * \\
5.58\end{array}$ & $\begin{array}{l}0.006^{* * * *} \\
\quad 6.70\end{array}$ & $\begin{array}{c}0.006^{* * *} \\
6.49\end{array}$ \\
\hline Cash compensation & $\begin{array}{c}0.000 \\
1.21\end{array}$ & $\begin{array}{l}-0.001 * * \\
-2.12\end{array}$ & $\begin{array}{l}-0.001 * * \\
-1.80\end{array}$ & $\begin{array}{l}-0.001 * * \\
-2.25\end{array}$ \\
\hline Log(sales) & $\begin{array}{c}0.000 \\
0.85\end{array}$ & $\begin{array}{l}0.003 * * * \\
4.30\end{array}$ & $\begin{array}{l}0.003 * * * \\
3.19\end{array}$ & $\begin{array}{l}0.003 * * * \\
3.96\end{array}$ \\
\hline Market-to-book & $\begin{array}{l}0.003 * * * \\
9.16\end{array}$ & $\begin{array}{c}0.003 * * * \\
17.20\end{array}$ & $\begin{array}{l}0.002 * * * \\
\quad 9.55\end{array}$ & $\begin{array}{l}0.002 * * * \\
9.34\end{array}$ \\
\hline Surplus cash & $\begin{array}{l}-0.015^{* * *} \\
-4.46\end{array}$ & $\begin{array}{l}0.010 * * * \\
4.37\end{array}$ & $\begin{array}{l}0.010 * * * \\
3.99\end{array}$ & $\begin{array}{c}0.013 * * * \\
3.71\end{array}$ \\
\hline Sales growth & $\begin{array}{c}0.016 * * * \\
14.74\end{array}$ & $\begin{array}{l}0.006 * * * \\
\quad 8.45\end{array}$ & $\begin{array}{l}0.004^{* * * *} \\
4.30\end{array}$ & $\begin{array}{l}0.003 * * * \\
3.23\end{array}$ \\
\hline Stock return & $\begin{array}{l}-0.000 \\
-0.90\end{array}$ & $\begin{array}{c}0.000 \\
1.07\end{array}$ & $\begin{array}{l}-0.000 \\
-0.25\end{array}$ & $\begin{array}{c}0.000 \\
0.14\end{array}$ \\
\hline Book leverage & $\begin{array}{c}-0.005^{*} \\
-1.88\end{array}$ & $\begin{array}{l}-0.015 * * * \\
-8.41\end{array}$ & $\begin{array}{c}-0.010 \text { *** } \\
-4.32\end{array}$ & $\begin{array}{c}-0.010 * * * \\
-4.24\end{array}$ \\
\hline Age & $\begin{array}{c}-0.000 * * \\
-2.29\end{array}$ & $\begin{array}{c}-0.000 \\
-0.13\end{array}$ & $\begin{array}{c}0.000 \\
0.28\end{array}$ & $\begin{array}{c}0.000 \\
0.05\end{array}$ \\
\hline Tenure & $\begin{array}{c}0.000 * * * \\
5.19\end{array}$ & $\begin{array}{c}-0.000 \\
-1.88\end{array}$ & $\begin{array}{c}-0.000 \\
-1.09\end{array}$ & $\begin{array}{c}-0.000 \\
-0.78\end{array}$ \\
\hline
\end{tabular}




\begin{tabular}{lcccc} 
Female & $0.002^{* *}$ & 0.000 & N/A & N/A \\
& 2.19 & 0.13 & & N/A \\
Mover & -0.001 & 0.003 & N/A & \\
& -0.61 & 0.92 & & 0.000 \\
CEO & & & 0.001 & 0.62 \\
& $-0.003^{* * *}$ & -0.000 & 1.19 & 0.001 \\
Director & -3.49 & -0.50 & 0.001 & 1.33 \\
& $0.001^{*}$ & 0.001 & 0.70 & Yes \\
Year Fixed Effects & 1.85 & 0.82 & Yes & 0.63 \\
\hline Adjusted R & Yes & Yes & 0.61 & 46,103 \\
N & 0.08 & 0.62 & 46,103 & \\
\hline
\end{tabular}

Panel B:

Relative Importance of Components in Determining CAPEX

\begin{tabular}{lcc}
\hline & $\frac{\operatorname{cov}(\text { CAPEX,component })}{\operatorname{var}(\text { CAPEX })}$ & $\begin{array}{c}\% \text { of } \mathrm{R}^{2} \text { attributable } \\
\text { to the component }\end{array}$ \\
\hline $\begin{array}{l}\text { Observable Firm } \\
\text { Characteristics }\end{array}$ & 0.080 & $10.67 \%$ \\
$\begin{array}{l}\text { Observable Manager } \\
\text { Characteristics }\end{array}$ & 0.001 & $0.13 \%$ \\
Firm Fixed Effects & 0.355 & $47.33 \%$ \\
Manager Fixed Effects & 0.312 & $41.60 \%$ \\
Year Fixed Effects & 0.003 & $0.40 \%$ \\
Residual & 0.250 & \\
\hline
\end{tabular}


Table 17

Observable and Unobservable Determinants of R\&D - Connectedness Sample with AKM Method

This table presents the results for specifications regressing corporate R\&D investment on observable managerial and firm characteristics and on various combinations of fixed effects that proxy for time and for unobserved manager and firm attributes. The benchmark specification (model (1) in Panel A) is a pooled OLS regression, without firm or manager fixed effects (FE), which is based on the explanatory variables in Table 3, Panel A, Column 1 in Coles, Daniel, and Naveen (2006) plus selected observable managerial attributes. Model (2) adds firm fixed effects only to the benchmark model, Model (3) adds manager fixed effects only, and Model (4) includes both firm and manager fixed effects. We include year fixed effects in all specifications. We delete observations with missing values for RHS variables included in the benchmark specification, but include observations with missing values of tenure and age by using indicator variables for whether each is missing. Panel B uses the coefficient estimates in specification (4) of Panel A to decompose model R-squared in order to quantify the relative importance of each class of variable in determining the portion of R\&D explained. Refer to the Appendix for variable definitions. Heteroskedasticity robust t-statistics clustered at the firm level are in parenthesis. $* * *, * *$, and $*$ indicate significance at the 1,5 , and $10 \%$ levels, respectively.

Panel A:

Dependent variable: $\mathbf{R} \& \mathbf{D}$

\begin{tabular}{|c|c|c|c|c|}
\hline & $\begin{array}{c}\text { (1) } \\
\text { Pooled OLS } \\
\text { (no firm or manager FE) }\end{array}$ & $\begin{array}{c}\text { (2) } \\
\text { Firm FE } \\
\text { (no manager FE) }\end{array}$ & $\begin{array}{c}(3) \\
\text { Manager FE } \\
\text { (no firm FE) }\end{array}$ & $\begin{array}{c}\text { (4) } \\
\text { Firm \& Manager } \\
\text { FE }\end{array}$ \\
\hline Vega & $\begin{array}{c}0.068 * * * \\
19.44\end{array}$ & $\begin{array}{c}0.013^{*} \\
1.58\end{array}$ & $\begin{array}{c}0.008 \\
0.49\end{array}$ & $\begin{array}{c}0.002 \\
0.24\end{array}$ \\
\hline Delta & $\begin{array}{l}-0.008 * * * \\
-3.15\end{array}$ & $\begin{array}{l}-0.000 \\
-0.26\end{array}$ & $\begin{array}{c}0.000 \\
0.31\end{array}$ & $\begin{array}{c}0.000 \\
0.15\end{array}$ \\
\hline Cash compensation & $\begin{array}{l}0.002 * * * \\
\quad 8.56\end{array}$ & $\begin{array}{l}-0.000 \\
-0.78\end{array}$ & $\begin{array}{c}0.000 \\
0.08\end{array}$ & $\begin{array}{l}-0.000 \\
-0.02\end{array}$ \\
\hline Log(sales) & $\begin{array}{c}-0.016^{* * *} \\
-83.91\end{array}$ & $\begin{array}{c}-0.010 * * * \\
-22.80\end{array}$ & $\begin{array}{l}-0.010 \\
0.77\end{array}$ & $\begin{array}{l}-0.010 * * * \\
-14.60\end{array}$ \\
\hline Market-to-book & $\begin{array}{l}0.010 * * * \\
31.16\end{array}$ & $\begin{array}{c}0.002 * * * \\
18.09\end{array}$ & $\begin{array}{l}0.002 * * * \\
8.74\end{array}$ & $\begin{array}{l}0.002 * * * \\
9.31\end{array}$ \\
\hline Surplus cash & $\begin{array}{l}0.189 * * * \\
62.90\end{array}$ & $\begin{array}{l}0.052 * * * \\
21.65\end{array}$ & $\begin{array}{l}0.049 * * * \\
25.91\end{array}$ & $\begin{array}{l}0.063 * * * \\
25.29\end{array}$ \\
\hline Sales growth & $\begin{array}{l}-0.023 * * * \\
-26.70\end{array}$ & $\begin{array}{l}-0.013 * * * \\
-17.47\end{array}$ & $\begin{array}{l}-0.013 * * * \\
-15.73\end{array}$ & $\begin{array}{c}-0.012 * * * \\
-13.04\end{array}$ \\
\hline Stock return & $\begin{array}{c}-0.001 * \\
-1.69\end{array}$ & $\begin{array}{l}-0.000 \\
-0.23\end{array}$ & $\begin{array}{l}-0.000 \\
-0.20\end{array}$ & $\begin{array}{l}-0.000 \\
-0.22\end{array}$ \\
\hline Book leverage & $\begin{array}{l}-0.023 * * * \\
-13.67\end{array}$ & $\begin{array}{l}0.013 * * * \\
\quad 8.76\end{array}$ & $\begin{array}{c}0.009 * * * \\
6.12\end{array}$ & $\begin{array}{c}0.013 * * * \\
6.79\end{array}$ \\
\hline Age & $\begin{array}{c}-0.000 * * * \\
-2.80\end{array}$ & $\begin{array}{c}0.000 \\
0.01\end{array}$ & $\begin{array}{c}-0.000 \\
-1.74\end{array}$ & $\begin{array}{c}0.000 \\
0.47\end{array}$ \\
\hline Tenure & $\begin{array}{c}-0.000 * \\
-1.98\end{array}$ & $\begin{array}{c}-0.000 \\
-0.79\end{array}$ & $\begin{array}{c}-0.000 \\
-0.09\end{array}$ & $\begin{array}{c}-0.000^{*} \\
-1.85\end{array}$ \\
\hline
\end{tabular}




\begin{tabular}{lcccc} 
Female & $-0.008^{* * *}$ & $-0.003^{* *}$ & N/A & N/A \\
& -6.99 & -1.92 & N/A & N/A \\
Mover & $0.003^{* * *}$ & 0.001 & & \\
& 5.07 & 0.85 & -0.001 & -0.001 \\
CEO & -0.001 & -0.001 & -1.24 & -1.30 \\
& -0.84 & -1.19 & -0.001 & -0.001 \\
Director & $-0.007 * * *$ & 0.001 & -1.01 & -0.78 \\
& -5.84 & 0.97 & & Yes \\
Year Fixed Effects & Yes & Yes & 0.78 & 0.80 \\
\hline Adjusted R $\mathrm{R}^{2}$ & 0.28 & 0.77 & 68,924 & 68,924 \\
$\mathrm{~N}$ & 68,924 & 68,924 & & \\
\hline
\end{tabular}

Panel B:

Relative Importance of Components in Determining R\&D

\begin{tabular}{lcc}
\hline & $\frac{\operatorname{cov}(R \& D, \text { component })}{\operatorname{var}(R \& D)}$ & $\begin{array}{c}\% \text { of } \mathrm{R}^{2} \text { attributable } \\
\text { to the component }\end{array}$ \\
\hline $\begin{array}{l}\text { Observable Firm } \\
\text { Obaracteristics }\end{array}$ & 0.110 & $12.87 \%$ \\
$\begin{array}{l}\text { Characteristics } \\
\text { Firm Fixed Effects }\end{array}$ & 0.001 & $0.12 \%$ \\
Manager Fixed Effects & 0.442 & $51.76 \%$ \\
Year Fixed Effects & 0.301 & $35.20 \%$ \\
Residual & 0.001 & $0.12 \%$ \\
\hline
\end{tabular}


Table 18

Observable and Unobservable Determinants of Firm Risk - Connectedness Sample with AKM Method

This table presents the results for specifications regressing firm stock volatility on observable managerial and firm characteristics and on various combinations of fixed effects that proxy for time and for unobserved manager and firm attributes. The benchmark specification (model (1) in Panel A) is a pooled OLS regression, without firm or manager fixed effects (FE), which is based on the explanatory variables in Table 9, Column 1 in Coles, Daniel, and Naveen (2006) plus selected observable managerial attributes. Model (2) adds firm fixed effects only to the benchmark model, Model (3) adds manager fixed effects only, and Model (4) includes both firm and manager fixed effects. We include year fixed effects in all specifications. We delete observations with missing values for RHS variables included in the benchmark specification, but include observations with missing values of tenure and age by using indicator variables for whether each is missing. Panel B uses the coefficient estimates in specification (4) of Panel A to decompose model R-squared in order to quantify the relative importance of each class of variable in determining the portion of firm risk explained. Refer to the Appendix for variable definitions. Heteroskedasticity robust t-statistics clustered at the firm level are in parenthesis. $* * *, * *$, and $*$ indicate significance at the 1,5 , and $10 \%$ levels, respectively.

Panel A:

Dependent variable: Firm Risk

\begin{tabular}{|c|c|c|c|c|}
\hline & $\begin{array}{c}\text { (1) } \\
\text { Pooled OLS } \\
\text { (no firm or manager FE) }\end{array}$ & $\begin{array}{c}(2) \\
\text { Firm FE } \\
\text { (no manager FE) }\end{array}$ & $\begin{array}{c}(3) \\
\text { Manager FE } \\
\text { (no firm FE) }\end{array}$ & $\begin{array}{c}\text { (4) } \\
\text { Firm \& Manager } \\
\text { FE }\end{array}$ \\
\hline Vega & $\begin{array}{c}-0.305 * * * \\
-8.90\end{array}$ & $\begin{array}{c}-0.186 * * * \\
-7.33\end{array}$ & $\begin{array}{c}-0.198 * * * \\
-6.28\end{array}$ & $\begin{array}{c}-0.169 * * * \\
-5.78\end{array}$ \\
\hline Delta & $\begin{array}{c}0.094 * * * \\
17.55\end{array}$ & $\begin{array}{c}0.030 * * * \\
7.74\end{array}$ & $\begin{array}{c}0.066^{* * * *} \\
8.95\end{array}$ & $\begin{array}{c}0.063 * * * \\
7.39\end{array}$ \\
\hline Cash compensation & $\begin{array}{c}-0.005^{* *} \\
-2.23\end{array}$ & $\begin{array}{c}-0.006 * * * \\
-2.83\end{array}$ & $\begin{array}{c}-0.010 * * * \\
-3.55\end{array}$ & $\begin{array}{c}-0.012 * * * \\
-5.28\end{array}$ \\
\hline $\log ($ sales $)$ & $\begin{array}{c}-0.192 * * * \\
-79.84\end{array}$ & $\begin{array}{c}-0.130 * * * \\
-25.13\end{array}$ & $\begin{array}{c}-0.132 * * * \\
-27.15\end{array}$ & $\begin{array}{c}-0.089 * * * \\
-12.80\end{array}$ \\
\hline Market-to-book & $\begin{array}{c}-0.025 * * * \\
-12.11\end{array}$ & $\begin{array}{c}-0.013 * * * \\
-3.84\end{array}$ & $\begin{array}{c}-0.015^{* * *} * \\
-6.89\end{array}$ & $\begin{array}{c}-0.015 * * * \\
-6.25\end{array}$ \\
\hline R\&D & $\begin{array}{c}2.652 * * * \\
55.13\end{array}$ & $\begin{array}{c}0.469 * * * \\
9.42\end{array}$ & $\begin{array}{c}0.429 * * * \\
8.40\end{array}$ & $\begin{array}{c}0.311 * * * \\
4.67\end{array}$ \\
\hline CAPEX & $\begin{array}{c}0.620 * * * \\
10.11\end{array}$ & $\begin{array}{l}-0.054 \\
-0.43\end{array}$ & $\begin{array}{c}0.085 \\
1.20\end{array}$ & $\begin{array}{c}0.079 \\
1.13\end{array}$ \\
\hline Book leverage & $\begin{array}{c}-0.076 * * * \\
-3.03\end{array}$ & $\begin{array}{c}0.314 * * * \\
19.73\end{array}$ & $\begin{array}{c}0.344 * * * \\
15.14\end{array}$ & $\begin{array}{c}0.308 * * * \\
14.51\end{array}$ \\
\hline Age & $\begin{array}{c}-0.012 * * \\
-16.07\end{array}$ & $\begin{array}{c}-0.002 \\
-0.46\end{array}$ & $\begin{array}{c}-0.002 \\
-0.80\end{array}$ & $\begin{array}{c}-0.002 \\
-0.39\end{array}$ \\
\hline Tenure & $\begin{array}{c}-0.007 * * * \\
-13.79\end{array}$ & $\begin{array}{c}-0.003 * * * \\
-6.22\end{array}$ & $\begin{array}{c}-0.018 * * * \\
-9.30\end{array}$ & $\begin{array}{c}-0.022 * * * \\
-10.42\end{array}$ \\
\hline Female & $\begin{array}{c}0.025^{*} \\
1.78\end{array}$ & $\begin{array}{c}-0.001 \\
-0.29\end{array}$ & N/A & N/A \\
\hline
\end{tabular}




\begin{tabular}{lcccc} 
Mover & -0.003 & 0.002 & $\mathrm{~N} / \mathrm{A}$ & $\mathrm{N} / \mathrm{A}$ \\
& -0.62 & 0.58 & & \\
$\mathrm{CEO}$ & 0.006 & -0.003 & 0.007 & 0.007 \\
& 0.64 & -0.12 & 0.60 & 0.73 \\
\multirow{2}{*}{ Director } & & & & $0.017^{* *}$ \\
& $-0.036^{* * *}$ & $0.011^{*}$ & $0.051^{* * *}$ & 2.36 \\
& -2.81 & 1.99 & 4.29 & Yes \\
Year Fixed Effects & Yes & Yes & Yes & 0.83 \\
\hline Adjusted $\mathrm{R}^{2}$ & 0.48 & 0.81 & 0.81 & 67,846 \\
$\mathrm{~N}$ & & & & 67,846 \\
\hline
\end{tabular}

Panel B:

Relative Importance of Components in Determining Firm Risk

\begin{tabular}{lcc}
\hline & $\frac{\operatorname{cov}(\text { FirmRisk,component })}{\operatorname{var}(\text { FirmRisk })}$ & $\begin{array}{c}\% \text { of } \mathrm{R}^{2} \text { attributable } \\
\text { to the component }\end{array}$ \\
$\begin{array}{l}\text { Observable Firm } \\
\begin{array}{l}\text { Obaracteristics } \\
\text { Observable Manager }\end{array}\end{array}$ & 0.070 & $7.96 \%$ \\
Firm Fixed Efristics & 0.013 & $1.85 \%$ \\
Manager Fixed Effects & 0.397 & $45.16 \%$ \\
Year Fixed Effects & 0.155 & $17.63 \%$ \\
Residual & 0.244 & $27.67 \%$ \\
\hline
\end{tabular}


Table 19

Observable and Unobservable Determinants of Herfindahl Index - Connectedness Sample with AKM Method

This table presents the results for specifications regressing company's Herfindahl index on observable managerial and firm characteristics and on various combinations of fixed effects that proxy for time and for unobserved manager and firm attributes. The benchmark specification (model (1) in Panel A) is a pooled OLS regression, without firm or manager fixed effects (FE), which is based on the explanatory variables in Table 4, Panel A, Column 1 in Coles, Daniel, and Naveen (2006) plus selected observable managerial attributes. Model (2) adds firm fixed effects only to the benchmark model, Model (3) adds manager fixed effects only, and Model (4) includes both firm and manager fixed effects. We include year fixed effects in all specifications. We delete observations with missing values for RHS variables included in the benchmark specification, but include observations with missing values of tenure and age by using indicator variables for whether each is missing. Panel B uses the coefficient estimates in specification (4) of Panel A to decompose model R-squared in order to quantify the relative importance of each class of variable in determining the portion of Herfindahl index explained. Refer to the Appendix for variable definitions. Heteroskedasticity robust tstatistics clustered at the firm level are in parenthesis. $* * *, * *$, and * indicate significance at the 1,5 , and $10 \%$ levels, respectively.

Panel A:

Dependent variable: Herfindahl Index

\begin{tabular}{|c|c|c|c|c|}
\hline & $\begin{array}{c}(1) \\
\text { Pooled OLS } \\
\text { (no firm or manager FE) }\end{array}$ & $\begin{array}{c}(2) \\
\text { Firm FE } \\
\text { (no manager FE) }\end{array}$ & $\begin{array}{c}(3) \\
\text { Manager FE } \\
\text { (no firm FE) }\end{array}$ & $\begin{array}{l}\text { (4) } \\
\text { Firm \& Manager } \\
\text { FE }\end{array}$ \\
\hline \multirow[t]{2}{*}{ Vega } & $-0.051 * * *$ & $0.025^{* *}$ & 0.007 & 0.013 \\
\hline & -4.13 & 2.62 & 0.33 & 0.62 \\
\hline \multirow[t]{2}{*}{ Delta } & $0.010 * * *$ & -0.001 & $0.007 * * *$ & $0.005 * *$ \\
\hline & 4.52 & -0.38 & 2.82 & 2.14 \\
\hline \multirow[t]{2}{*}{ Cash compensation } & $-0.005 * * *$ & $0.004 * * *$ & $0.005 * * *$ & $0.005 * * *$ \\
\hline & -3.65 & 5.97 & 5.38 & 5.62 \\
\hline \multirow[t]{2}{*}{ Log(sales) } & $-0.045 * * *$ & $-0.067 * * *$ & $-0.060 * * *$ & $-0.060 * * *$ \\
\hline & -41.60 & -36.97 & -35.63 & -25.97 \\
\hline \multirow[t]{2}{*}{ Market-to-book } & $0.013 * * *$ & $0.006 * * *$ & $0.006^{* * *}$ & $0.005 * * *$ \\
\hline & 20.38 & 5.56 & 6.41 & 5.83 \\
\hline \multirow[t]{2}{*}{ ROA } & $0.041 * * *$ & $0.131 * * *$ & $0.092 * * *$ & $0.095 * * *$ \\
\hline & 5.73 & 13.26 & 6.07 & 7.71 \\
\hline \multirow[t]{2}{*}{ Stock return } & $-0.008 * * *$ & $-0.006 * * *$ & -0.003 & -0.002 \\
\hline & -3.83 & -3.37 & -1.42 & -1.01 \\
\hline \multirow[t]{2}{*}{ Sales growth } & $0.028 * * *$ & -0.008 & -0.000 & $-0.007 * *$ \\
\hline & 6.23 & -0.71 & -0.13 & -2.11 \\
\hline \multirow[t]{2}{*}{ Dividend cut } & $-0.074 * * *$ & $-0.005^{* *}$ & $-0.006 * * *$ & -0.003 \\
\hline & -27.72 & -2.37 & -2.85 & -0.99 \\
\hline \multirow[t]{2}{*}{ CEO turnover } & -0.000 & $-0.005 * * *$ & $-0.005 * * *$ & $-0.005 * * *$ \\
\hline & -0.25 & -2.74 & -2.79 & -2.92 \\
\hline Book leverage & $-0.044 * * *$ & $-0.080 * * *$ & $-0.047 * * *$ & $-0.060 * * *$ \\
\hline
\end{tabular}




\begin{tabular}{|c|c|c|c|c|}
\hline & -5.54 & -11.91 & -5.96 & -7.01 \\
\hline Age & $\begin{array}{c}-0.001 * * \\
-10.74\end{array}$ & $\begin{array}{c}-0.000 \\
0.78\end{array}$ & $\begin{array}{c}0.000 \\
0.66\end{array}$ & $\begin{array}{c}0.001^{*} \\
1.62\end{array}$ \\
\hline Tenure & $\begin{array}{c}-0.001 * * * \\
-5.86\end{array}$ & $\begin{array}{l}-0.000 \\
-0.99\end{array}$ & $\begin{array}{c}-0.002 * * * \\
-3.93\end{array}$ & $\begin{array}{l}-0.001 \\
-1.31\end{array}$ \\
\hline Female & $\begin{array}{c}0.046^{* * * *} \\
8.37\end{array}$ & $\begin{array}{c}0.002 \\
0.46\end{array}$ & N/A & N/A \\
\hline Mover & $\begin{array}{c}-0.021 * * * \\
-5.24\end{array}$ & $\begin{array}{l}-0.005 \\
-0.50\end{array}$ & N/A & N/A \\
\hline CEO & $\begin{array}{c}-0.002 \\
-0.36\end{array}$ & $\begin{array}{l}-0.003 \\
-1.05\end{array}$ & $\begin{array}{c}-0.002 \\
-0.69\end{array}$ & $\begin{array}{l}-0.002 \\
-0.52\end{array}$ \\
\hline Director & $\begin{array}{c}0.030 * * * \\
5.82\end{array}$ & $\begin{array}{c}0.008 \\
0.68\end{array}$ & $\begin{array}{c}0.020 * * * \\
4.70\end{array}$ & $\begin{array}{c}0.018^{* * *} \\
2.79\end{array}$ \\
\hline Year Fixed Effects & Yes & Yes & Yes & Yes \\
\hline Adjusted $\mathrm{R}^{2}$ & 0.16 & 0.73 & 0.75 & 0.79 \\
\hline $\mathrm{N}$ & 61825 & 61825 & 61825 & 61825 \\
\hline
\end{tabular}

Panel B:

Relative Importance of Components in Determining Herfindahl Index

\begin{tabular}{lcc}
\hline & $\frac{\operatorname{cov}(\text { HerfindahlIndex,component })}{\operatorname{var}(\text { HerfindahlIndex })}$ & $\begin{array}{c}\% \text { of } \mathrm{R}^{2} \text { attributable } \\
\text { to the component }\end{array}$ \\
\hline $\begin{array}{l}\text { Observable Firm } \\
\text { Characteristics }\end{array}$ & 0.112 & $13.13 \%$ \\
$\begin{array}{l}\text { Observable Manager } \\
\text { Characteristics }\end{array}$ & 0.001 & $0.12 \%$ \\
Firm Fixed Effects & 0.390 & $45.72 \%$ \\
Manager Fixed Effects & 0.320 & $37.51 \%$ \\
Year Fixed Effects & 0.030 & $3.52 \%$ \\
Residual & 0.147 & \\
\hline
\end{tabular}


Table 20

Observable and Unobservable Determinants of Business Segments - Connectedness Sample with AKM Method

This table presents the results for specifications regressing $\operatorname{Ln}$ (segments) on observable managerial and firm characteristics and on various combinations of fixed effects that proxy for time and for unobserved manager and firm attributes. The benchmark specification (model (1) in Panel A) is a pooled OLS regression, without firm or manager fixed effects (FE), which is based on the explanatory variables in Table 4, Panel B, Column 1 in Coles, Daniel, and Naveen (2006) plus selected observable managerial attributes. Model (2) adds firm fixed effects only to the benchmark model, Model (3) adds manager fixed effects only, and Model (4) includes both firm and manager fixed effects. We include year fixed effects in all specifications. We delete observations with missing values for RHS variables included in the benchmark specification, but include observations with missing values of tenure and age by using indicator variables for whether each is missing. Panel B uses the coefficient estimates in specification (4) of Panel A to decompose model R-squared in order to quantify the relative importance of each class of variable in determining the portion of Ln(segments) explained. Refer to the Appendix for variable definitions. Heteroskedasticity robust t-statistics clustered at the firm level are in parenthesis. $* * *, * *$, and $*$ indicate significance at the 1,5 , and $10 \%$ levels, respectively.

Panel A:

Dependent variable: $\operatorname{Ln}($ segments)

\begin{tabular}{|c|c|c|c|c|}
\hline & $\begin{array}{c}\text { (1) } \\
\text { Pooled OLS } \\
\text { (no firm or manager FE) }\end{array}$ & $\begin{array}{c}\text { (2) } \\
\text { Firm FE } \\
\text { (no manager FE) }\end{array}$ & $\begin{array}{c}(3) \\
\text { Manager FE } \\
\text { (no firm FE) }\end{array}$ & $\begin{array}{c}(4) \\
\text { Firm \& Manager } \\
\text { FE }\end{array}$ \\
\hline \multirow[t]{2}{*}{ Vega } & $0.125 * * *$ & -0.016 & $0.044^{*}$ & 0.030 \\
\hline & 3.68 & -0.67 & 1.51 & 0.96 \\
\hline \multirow[t]{2}{*}{ Delta } & $-0.031 * * *$ & 0.004 & $-0.013 * * *$ & -0.011 \\
\hline & -5.39 & 1.15 & -2.94 & -1.29 \\
\hline \multirow[t]{2}{*}{ Cash compensation } & $0.016 * * *$ & $-0.007 * * *$ & $-0.005 *$ & $-0.006 * * *$ \\
\hline & 6.61 & -3.22 & -1.84 & -4.06 \\
\hline \multirow[t]{2}{*}{ Log(sales) } & $0.112 * * *$ & $0.136 * * *$ & $0.130 * * *$ & $0.128 * * *$ \\
\hline & 52.41 & 30.97 & 28.21 & 18.82 \\
\hline \multirow[t]{2}{*}{ Market-to-book } & $-0.047 * * *$ & $-0.005 * *$ & $-0.010^{* * *}$ & $-0.010 * * *$ \\
\hline & -22.20 & -2.18 & -4.62 & -3.96 \\
\hline \multirow[t]{2}{*}{ ROA } & $-0.212 * * *$ & $-0.281 * * *$ & $-0.145^{* * *}$ & $-0.140 * * *$ \\
\hline & -9.88 & -8.30 & -5.14 & -5.34 \\
\hline \multirow[t]{2}{*}{ Stock return } & $0.006^{* *}$ & 0.003 & 0.003 & 0.002 \\
\hline & 2.16 & 1.08 & 0.74 & 0.50 \\
\hline \multirow[t]{2}{*}{ Sales growth } & $-0.042 * * *$ & $0.028 * * *$ & $0.012 * *$ & $0.025 * * *$ \\
\hline & -4.10 & 4.43 & 2.11 & 3.44 \\
\hline \multirow[t]{2}{*}{ Dividend cut } & $0.176 * * *$ & 0.001 & $0.011 * *$ & 0.001 \\
\hline & 27.76 & 0.82 & 2.17 & 0.91 \\
\hline \multirow[t]{2}{*}{ CEO turnover } & 0.003 & $0.012 * * *$ & $0.014 * * *$ & $0.012 * * *$ \\
\hline & 0.43 & 2.91 & 3.10 & 3.03 \\
\hline \multirow[t]{2}{*}{ Book leverage } & $0.130 * * *$ & $0.228 * * *$ & $0.127 * * *$ & $0.145^{* * *}$ \\
\hline & 7.83 & 13.82 & 6.83 & 7.14 \\
\hline
\end{tabular}




\begin{tabular}{|c|c|c|c|c|}
\hline Age & $\begin{array}{c}0.006 * * * \\
14.14\end{array}$ & $\begin{array}{l}-0.001 \\
-1.31\end{array}$ & $\begin{array}{c}-0.004 * * * \\
-2.90\end{array}$ & $\begin{array}{c}-0.003^{*} \\
-1.91\end{array}$ \\
\hline Tenure & $\begin{array}{c}0.003 * * * \\
4.84\end{array}$ & $\begin{array}{c}0.001 \\
0.73\end{array}$ & $\begin{array}{c}0.003 * * * \\
3.20\end{array}$ & $\begin{array}{c}0.000 \\
0.28\end{array}$ \\
\hline Female & $\begin{array}{c}-0.087 * * * \\
-7.59\end{array}$ & $\begin{array}{l}-0.005 \\
-0.49\end{array}$ & N/A & N/A \\
\hline Mover & $\begin{array}{c}0.019^{*} \\
1.84\end{array}$ & $\begin{array}{c}0.008 \\
0.38\end{array}$ & N/A & N/A \\
\hline CEO & $\begin{array}{c}-0.010 \\
-0.21\end{array}$ & $\begin{array}{c}0.011 \\
0.68\end{array}$ & $\begin{array}{c}0.005 \\
0.57\end{array}$ & $\begin{array}{c}0.009 \\
1.12\end{array}$ \\
\hline Director & $\begin{array}{c}-0.045^{* * *} \\
-5.39\end{array}$ & $\begin{array}{c}-0.009^{*} \\
-1.32\end{array}$ & $\begin{array}{c}-0.050^{* * *} \\
-4.47\end{array}$ & $\begin{array}{c}-0.051 * * * \\
-4.11\end{array}$ \\
\hline Year Fixed Effects & Yes & Yes & Yes & Yes \\
\hline Adjusted $\mathrm{R}^{2}$ & 0.21 & 0.73 & 0.75 & 0.79 \\
\hline $\mathrm{N}$ & 61,825 & 61,825 & 61,825 & 61,825 \\
\hline
\end{tabular}

Panel B:

Relative Importance of Components in Determining Ln(segments)

\begin{tabular}{lcc}
\hline & $\frac{\operatorname{cov}(\text { Ln (segments) } \text { component })}{\operatorname{var}(\text { Ln(segments }))}$ & $\begin{array}{c}\% \text { of } \mathrm{R}^{2} \text { attributable } \\
\text { to the component }\end{array}$ \\
\hline $\begin{array}{l}\text { Observable Firm } \\
\text { Characteristics }\end{array}$ & 0.100 & $11.72 \%$ \\
$\begin{array}{l}\text { Observable Manager } \\
\text { Characteristics }\end{array}$ & 0.004 & $0.49 \%$ \\
Firm Fixed Effects & 0.380 & $44.55 \%$ \\
Manager Fixed Effects & 0.298 & $34.84 \%$ \\
Year Fixed Effects & 0.071 & $8.32 \%$ \\
Residual & 0.147 & \\
\hline
\end{tabular}


Table 21

Observable and Unobservable Determinants of Tobin's Q - Connectedness Sample with AKM Method

This table presents the results for specifications regressing company's Tobin's Q on observable managerial and firm characteristics and on various combinations of fixed effects that proxy for time and for unobserved manager and firm attributes. The benchmark specification (model (1) in Panel A) is a pooled OLS regression, without firm or manager fixed effects (FE), which is based on the explanatory variables in Table 4, Panel A, Column 4 in Mehran (1995) plus selected observable managerial attributes. Model (2) adds firm fixed effects only to the benchmark model, Model (3) adds manager fixed effects only, and Model (4) includes both firm and manager fixed effects. We include year fixed effects in all specifications. We delete observations with missing values for RHS variables included in the benchmark specification, but include observations with missing values of tenure and age by using indicator variables for whether each is missing. Panel B uses the coefficient estimates in specification (4) of Panel A to decompose model R-squared in order to quantify the relative importance of each class of variable in determining the portion of Tobin's Q explained. Refer to the Appendix for variable definitions. Heteroskedasticity robust t-statistics clustered at the firm level are in parenthesis. $* * *, * *$, and $*$ indicate significance at the 1,5 , and $10 \%$ levels, respectively.

\section{Panel A:}

Dependent variable: Tobin's Q

\begin{tabular}{|c|c|c|c|c|}
\hline & $\begin{array}{c}\text { (1) } \\
\text { Pooled OLS } \\
\text { (no firm or manager FE) }\end{array}$ & $\begin{array}{c}\text { (2) } \\
\text { Firm FE } \\
\text { (no manager FE) }\end{array}$ & $\begin{array}{c}(3) \\
\text { Manager FE } \\
\text { (no firm FE) }\end{array}$ & $\begin{array}{c}\text { (4) } \\
\text { Firm \& Manager } \\
\text { FE }\end{array}$ \\
\hline$\%$ of managers' & $0.725 * * *$ & $0.223 * * *$ & $0.183 * * *$ & $0.170 * * *$ \\
\hline equity compensation & 22.83 & 8.04 & 6.55 & 6.18 \\
\hline Managers' delta & $\begin{array}{l}0.381 * * * \\
28.15\end{array}$ & $\begin{array}{l}0.058 * * * \\
5.76\end{array}$ & $\begin{array}{l}-0.062 * * * \\
-3.75\end{array}$ & $\begin{array}{c}-0.059 * * * \\
-3.63\end{array}$ \\
\hline $\begin{array}{l}\% \text { of shares held by all } \\
\text { outside blockholders }\end{array}$ & $\begin{array}{c}0.207 * * \\
2.35\end{array}$ & $\begin{array}{l}0.129 * * * \\
\quad 4.15\end{array}$ & $\begin{array}{l}0.084 * * \\
2.12\end{array}$ & $\begin{array}{l}0.151 * * * \\
\quad 3.97\end{array}$ \\
\hline$\%$ of outside directors & $\begin{array}{l}-0.374 * * * \\
-6.80\end{array}$ & $\begin{array}{c}0.010 \\
0.31\end{array}$ & $\begin{array}{c}0.074 \\
1.48\end{array}$ & $\begin{array}{c}0.138 * * \\
2.52\end{array}$ \\
\hline R\&D/sales & $\begin{array}{l}5.328 * * * \\
35.68\end{array}$ & $\begin{array}{l}3.010 * * * \\
14.51\end{array}$ & $\begin{array}{l}3.002 * * * \\
12.05\end{array}$ & $\begin{array}{l}0.992 * * * \\
3.74\end{array}$ \\
\hline$($ Inventory+PPE)/assets & $\begin{array}{l}-0.594 * * * \\
-8.37\end{array}$ & $\begin{array}{l}-1.113^{* * *} \\
-11.51\end{array}$ & $\begin{array}{c}-0.591 * * * \\
-5.19\end{array}$ & $\begin{array}{c}-0.980 * * * \\
-8.29\end{array}$ \\
\hline Long-term debt/assets & $\begin{array}{c}-0.174 * * * \\
-31.90\end{array}$ & $\begin{array}{c}-0.137 * * * \\
-21.23\end{array}$ & $\begin{array}{c}-0.108 * * * \\
-15.47\end{array}$ & $\begin{array}{c}-0.096 * * * \\
-15.07\end{array}$ \\
\hline $\begin{array}{l}\text { Std of \% change in } \\
\text { operating income }\end{array}$ & $\begin{array}{l}0.103 * * * \\
5.01\end{array}$ & $\begin{array}{l}-0.570 * * * \\
-21.50\end{array}$ & $\begin{array}{c}-0.391 * * * \\
-12.11\end{array}$ & $\begin{array}{c}-0.429 * * * \\
-15.28\end{array}$ \\
\hline Log of assets & $\begin{array}{l}0.028 * * * \\
5.29\end{array}$ & $\begin{array}{c}-0.723 * * * \\
-44.83\end{array}$ & $\begin{array}{c}-0.352 * * * \\
-22.32\end{array}$ & $\begin{array}{c}-0.634 * * * \\
-30.71\end{array}$ \\
\hline Age & $\begin{array}{l}-0.010 * * * \\
-6.26\end{array}$ & $\begin{array}{l}-0.009 \\
-1.07\end{array}$ & $\begin{array}{l}-0.015 * * \\
-2.55\end{array}$ & $\begin{array}{l}-0.009 \\
-0.73\end{array}$ \\
\hline Tenure & $\begin{array}{c}0.012 * * \\
2.49\end{array}$ & $\begin{array}{l}-0.000 \\
-0.35\end{array}$ & $\begin{array}{c}-0.010 * * \\
-2.62\end{array}$ & $\begin{array}{c}-0.010 * \\
-1.69\end{array}$ \\
\hline
\end{tabular}




\begin{tabular}{lcccc} 
Female & 0.054 & -0.003 & N/A & N/A \\
& 1.60 & -0.04 & & N/A \\
Mover & $-0.210^{* * *}$ & $-0.034^{* *}$ & N/A & \\
& -10.12 & -2.33 & & -0.005 \\
CEO & $-0.246^{* * *}$ & $-0.071^{* * *}$ & $-0.044^{*}$ & -0.81 \\
& -7.29 & -3.18 & -1.91 & $0.093^{* * *}$ \\
Director & -0.051 & $0.050^{*}$ & 0.021 & 2.96 \\
& -0.80 & 1.87 & 0.81 & Yes \\
Year Fixed Effects & Yes & Yes & Yes & 0.74 \\
\hline Adjusted R & 0.23 & 0.70 & 0.71 & 31,918 \\
N & 31,918 & 31,918 & 31,918 & \\
\hline
\end{tabular}

Panel B:

Relative Importance of Components in Determining Tobin's Q

\begin{tabular}{lcc}
\hline & $\frac{\operatorname{cov}(Q, \text { component })}{\operatorname{var}(Q)}$ & $\begin{array}{c}\% \text { of } \mathrm{R}^{2} \text { attributable } \\
\text { to the component }\end{array}$ \\
\hline $\begin{array}{l}\text { Observable Firm } \\
\text { Characteristics }\end{array}$ & 0.045 & $5.45 \%$ \\
$\begin{array}{l}\text { Observable Manager } \\
\text { Characteristics }\end{array}$ & 0.003 & $0.36 \%$ \\
Firm Fixed Effects & 0.360 & $43.63 \%$ \\
Manager Fixed Effects & 0.397 & $48.12 \%$ \\
Year Fixed Effects & 0.020 & $2.43 \%$ \\
Residual & 0.176 & \\
\hline
\end{tabular}


Table 22

Observable and Unobservable Determinants of ROA - Connectedness Sample with AKM Method

This table presents the results for specifications regressing company's ROA on observable managerial and firm characteristics and on various combinations of fixed effects that proxy for time and for unobserved manager and firm attributes. The benchmark specification (model (1) in Panel A) is a pooled OLS regression, without firm or manager fixed effects (FE), which is based on the explanatory variables in Table 4, Panel B, Column 4 in Mehran (1995) plus selected observable managerial attributes. Model (2) adds firm fixed effects only to the benchmark model, Model (3) adds manager fixed effects only, and Model (4) includes both firm and manager fixed effects. We include year fixed effects in all specifications. We delete observations with missing values for RHS variables included in the benchmark specification, but include observations with missing values of tenure and age by using indicator variables for whether each is missing. Panel B uses the coefficient estimates in specification (4) of Panel A to decompose model R-squared in order to quantify the relative importance of each class of variable in determining the portion of ROA explained. Refer to the Appendix for variable definitions. Heteroskedasticity robust t-statistics clustered at the firm level are in parenthesis. $* * *, * *$, and $*$ indicate significance at the 1,5 , and $10 \%$ levels, respectively.

Panel A:

Dependent variable: ROA

\begin{tabular}{|c|c|c|c|c|}
\hline & $\begin{array}{c}\text { (1) } \\
\text { Pooled OLS } \\
\text { (no firm or manager FE) }\end{array}$ & $\begin{array}{c}\text { (2) } \\
\text { Firm FE } \\
\text { (no manager FE) }\end{array}$ & $\begin{array}{c}(3) \\
\text { Manager FE } \\
\text { (no firm FE) }\end{array}$ & $\begin{array}{c}\text { (4) } \\
\text { Firm \& Manager } \\
\text { FE } \\
\end{array}$ \\
\hline$\%$ of managers' & $2.267 * * *$ & $0.436 * * *$ & $0.287 *$ & 0.269 \\
\hline equity compensation & 8.23 & 2.68 & 1.70 & 1.38 \\
\hline \multirow[t]{2}{*}{ Managers' delta } & $1.009 * * *$ & $0.243 * * *$ & 0.122 & $0.254 * *$ \\
\hline & 9.54 & 3.58 & 1.03 & 2.19 \\
\hline \multirow{2}{*}{$\begin{array}{l}\% \text { of shares held by all } \\
\text { outside blockholders }\end{array}$} & $1.880 * * *$ & $0.639 * * *$ & $0.774 * * *$ & $0.848 * * *$ \\
\hline & 4.80 & 3.15 & 2.93 & 3.58 \\
\hline \multirow[t]{2}{*}{$\%$ of outside directors } & $1.882 * * *$ & 0.437 & -0.540 & -0.141 \\
\hline & 5.43 & 0.88 & -1.18 & -0.44 \\
\hline \multirow[t]{2}{*}{ R\&D/sales } & $-22.774 * * *$ & $-9.795 * * *$ & $-20.159 * * *$ & $-18.045 * * *$ \\
\hline & -19.65 & -5.86 & -10.06 & -9.18 \\
\hline \multirow[t]{2}{*}{$($ Inventory+PPE)/assets } & $6.716^{* * *}$ & $1.703 * *$ & $5.087 * * *$ & $1.378 *$ \\
\hline & 22.87 & 2.47 & 7.49 & 1.69 \\
\hline \multirow[t]{2}{*}{ Long-term debt/assets } & $-1.256 * * *$ & $-0.903 * * *$ & $-0.978 * * *$ & $-0.879 * * *$ \\
\hline & -29.38 & -22.52 & -22.04 & -19.33 \\
\hline \multirow{2}{*}{$\begin{array}{l}\text { Std of \% change in } \\
\text { operating income }\end{array}$} & $-6.083 * * *$ & $-10.184 * * *$ & $-8.402 * * *$ & $-9.081 * * *$ \\
\hline & -33.25 & -50.08 & -33.87 & -34.20 \\
\hline \multirow[t]{2}{*}{ Log of assets } & $-0.216 * * *$ & $-1.871 * * *$ & $-1.124 * * *$ & $-2.379 * * *$ \\
\hline & -4.99 & -17.42 & -10.10 & -15.84 \\
\hline \multirow[t]{2}{*}{ Age } & $-0.035 * * *$ & -0.008 & 0.031 & 0.008 \\
\hline & -3.45 & -0.34 & 0.51 & 0.49 \\
\hline \multirow[t]{2}{*}{ Tenure } & $0.068 * * *$ & -0.002 & $0.055 * *$ & $0.079 * *$ \\
\hline & 7.08 & -0.26 & 2.08 & 2.10 \\
\hline
\end{tabular}




\begin{tabular}{lcccc} 
Female & $0.883^{* * *}$ & -0.018 & N/A & N/A \\
& 4.53 & -0.16 & & N/A \\
Mover & $-0.923^{* * *}$ & -0.020 & & \\
& -5.50 & -0.71 & & $0.335^{*}$ \\
CEO & $-0.404^{*}$ & 0.048 & 1.18 & 1.81 \\
& -1.79 & 0.39 & 0.029 & $0.410^{*}$ \\
Director & -0.113 & 0.001 & 0.43 & 1.77 \\
& -1.02 & 0.01 & Yes & Yes \\
Year Fixed Effects & Yes & Yes & 0.73 & 0.76 \\
\hline Adjusted R & 0.17 & 0.72 & 31,918 & 31,918 \\
$\mathrm{~N}$ & 31,918 & 31,918 & & \\
\hline
\end{tabular}

Panel B:

Relative Importance of Components in Determining ROA

\begin{tabular}{lcc}
\hline & $\frac{\operatorname{cov}(\text { ROA, component })}{\operatorname{var}(\text { ROA })}$ & $\begin{array}{c}\text { \% of } \mathrm{R}^{2} \text { attributable } \\
\text { to the component }\end{array}$ \\
\hline $\begin{array}{l}\text { Observable Firm } \\
\text { Characteristics }\end{array}$ & 0.119 & $14.42 \%$ \\
$\begin{array}{l}\text { Observable Manager } \\
\text { Characteristics }\end{array}$ & 0.012 & $1.45 \%$ \\
Firm Fixed Effects & 0.429 & $52.00 \%$ \\
Manager Fixed Effects & 0.244 & $29.57 \%$ \\
Year Fixed Effects & 0.021 & $2.54 \%$ \\
Residual & 0.175 & \\
\hline
\end{tabular}

